
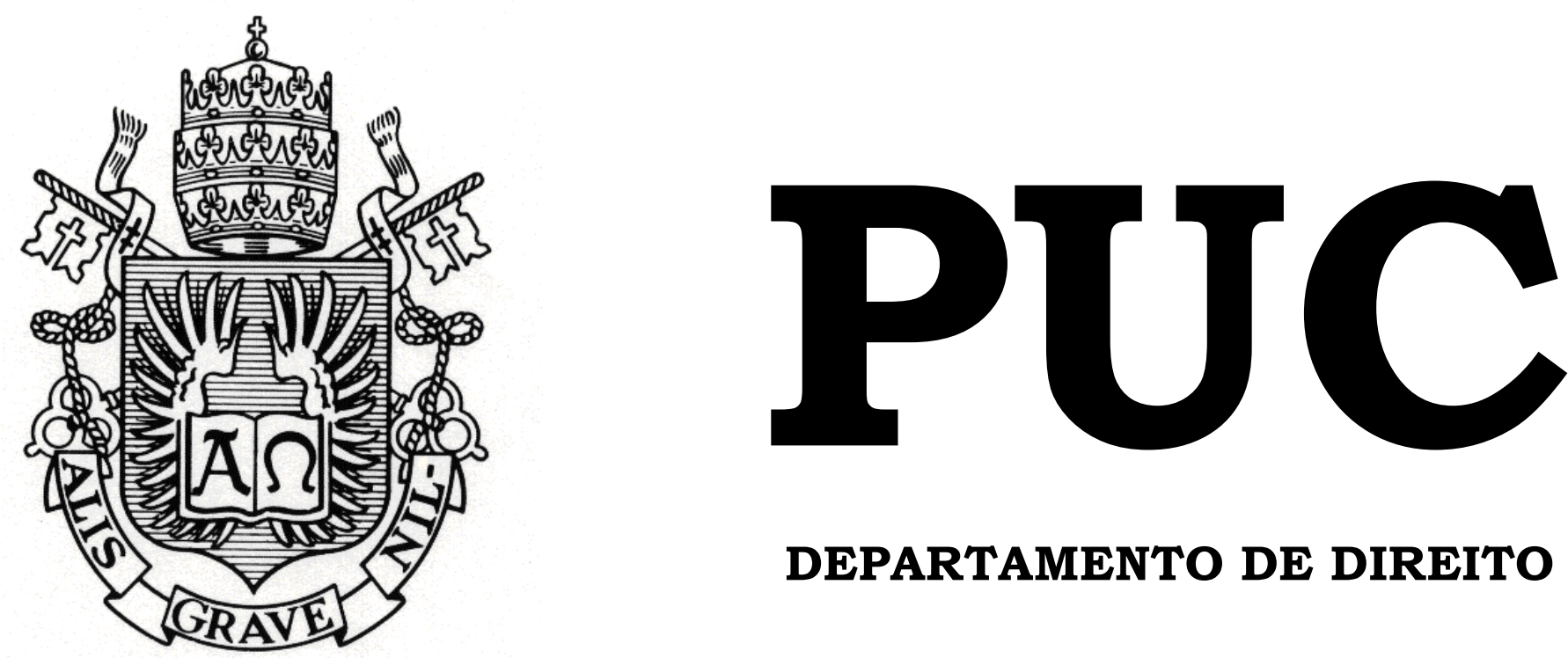

DEPARTAMENTO DE DIREITO

Prova Indiciária na Responsabilização de Insider Trading nos Precedentes da Comissão de Valores Mobiliários

por

Bianca Napoli Figueiredo

ORIENTADORA: Norma Jonssen Parente 2017.2

PONTIFÍCIA UNIVERSIDADE CATÓLICA DO RIO DE JANEIRO RUA MARQUÊS DE SÃO VICENTE, 225 - CEP 22453-900 RIO DE JANEIRO - BRASIL 


\section{Prova Indiciária na Responsabilização de Insider Trading nos Precedentes da Comissão de Valores Mobiliários}

por

Bianca Napoli Figueiredo

Monografia

apresentada

ao

Departamento de Direito da Pontificia Universidade Católica do Rio de Janeiro (PUC-Rio) para a obtenção do Título de Bacharel em Direito.

Orientadora: Norma Jonssen Parente 
"A mercadoria mais valiosa que conheço é a informação." Wall Street (1987). Dir.: Oliver Stone. 


\section{AGRADECIMENTOS}

Aos meus pais, Cynthia e Volney, por todo afeto e por sempre colocarem meus estudos em primeiro lugar.

À minha família pelo carinho e suporte incondicional.

Ao Rodolfo por todo amor e pela compreensão nos longos dias de estudo.

Aos meus amigos por tornarem a minha trajetória mais fácil e, com certeza, bem mais divertida.

À Luiza Chaves por caminhar essa trajetória ao meu lado, até nos momentos mais difíceis.

Aos meus professores por me ensinarem e, mais do que isso, me instigarem a pensar.

À equipe do Veirano de Mercado de Capitais pelo companheirismo e pelos ensinamentos diários. 


\section{Resumo}

FIGUEIREDO, Bianca Napoli. - Prova Indiciária na Responsabilização de Insider Trading nos Precedentes da Comissão de Valores Mobiliários - Pontifícia Universidade Católica do Rio de Janeiro: Rio de Janeiro, 2017.

O presente tem como intuito promover uma reflexão sobre decisões do Colegiado no âmbito de julgamento de Processo Administrativo Sancionador pela prática de insider trading com base em indícios e contra indícios. Para tanto, primeiro, foi apresentado o entendimento consolidado da Comissão de Valores Mobiliários sobre a utilização da prova indiciária para fundamentar tais decisões. Além disso, no presente foram analisados os indícios e contra indícios usualmente utilizados para justificar a condenação e a absolvição dos acusados no âmbito julgamento pelo Colegiado de Processo Administrativo Sancionador para apuração o uso indevido de informação privilegiada, inclusive, expondo o posicionamento da Comissão de Valores Mobiliários sobre cada um dos indícios e contra indícios.

Palavras Chave: Mercado de Capitais - Insider Trading - Uso Indevido de Informação Privilegiada - Insider Primário e Insider Secundário - Prova Indiciária - Indícios - Processo Administrativo Sancionador - Comissão de Valores Mobiliários. 


\section{Sumário}

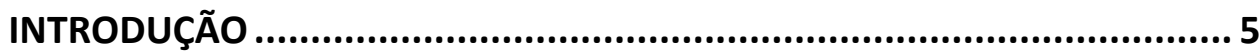

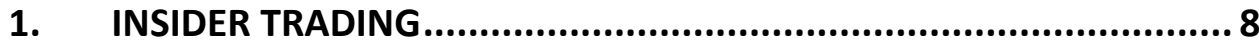

1.1. Regulamentação da Informação no Mercado de Capitais ..................8

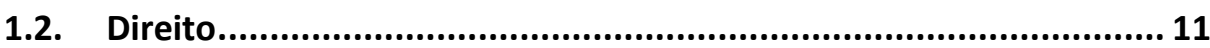

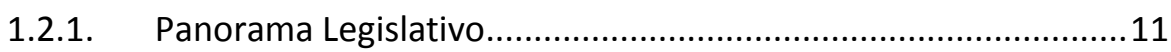

1.2.2. Regulamentação da Comissão de Valores Mobiliários ................16

1.3. O Insider Trader........................................................................... 18

1.3.1. Quem pode ser Insider? ..........................................................18

1.3.2. Insider Primário e Insider Secundário ............................................20

1.4. Configuração da Prática de Insider Trading ....................................... 25

1.4.1. Informação Relevante não divulgada ao mercado........................26

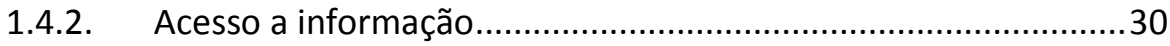

1.4.3. Utilização da Informação Privilegiada .........................................33

1.4.4. Intenção de obter vantagem indevida .......................................34

1.5. Responsabilização Civil, Administrativa e Penal ............................. 36

2. CONSIDERAÇÕES SOBRE A PROVA INDICIÁRIA ......................... 42

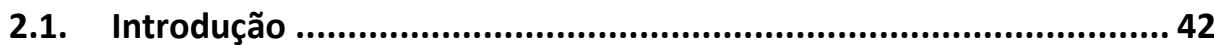

2.2. Conceito e Valor Probante da Prova Indiciária ................................ 44

2.3. Prova Indiciária e Insider Trading .............................................. 47

3. INDÍCIOS E CONTRA INDICÍOS DA PRÁTICA DE INSIDER TRADING57

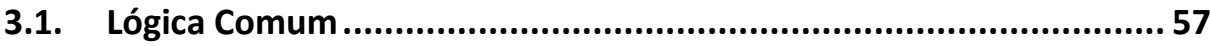

3.2. Indícios e Contra Indícios Usuais em Processos Sancionadores ........ 61

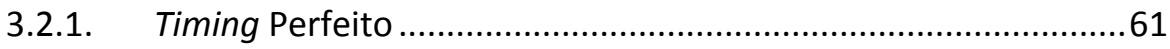

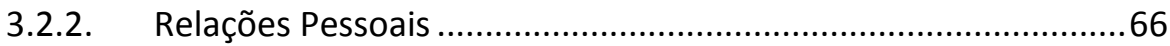

3.2.3. Perfil de Negociação ..............................................................72

3.2.4. Demais Condutas do Investidor ..............................................77

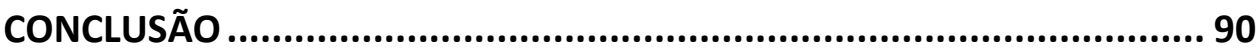




\section{INTRODUÇÃO}

Há quem diga que a prática do uso indevido de informações privilegiadas (comumente conhecido como insider trading) é o crime mais grave que pode ocorrer no mercado de capitais ${ }^{1}$. Tal prática afeta diretamente a viabilidade e eficiência do mercado de capitais, além de, muitas vezes, representar uma quebra de dever fiduciário frente à companhia emissora de valores mobiliários.

Assim, como será visto no presente, na busca pela erradicação da referida prática e em razão da rara existência de provas diretas do delito, a Comissão de Valores Mobiliários adotou o entendimento, em linha com o artigo 239 do Código de Processo Penal e com o posicionamento atual do Supremo Tribunal Federal, de que a prova indiciária é suficiente para fundamentar a decisão do Colegiado.

Bom, se por um lado, a existência de prova direta normalmente é escassa, por outro, a prática de insider trading costuma deixar um rastro de indícios. Analisados e apurados pela Comissão de Valores Mobiliários, os indícios são a principal fonte de fundamentação das decisões do Colegiado, principalmente, quando aquele que pratica o ilícito não possui vínculo direto com a companhia.

Certos da relevância dos indícios para a apuração da responsabilidade do crime mais grave que pode ocorrer no mercado de capitais, faz-se necessária uma análise minuciosa dos principais indícios e, consequentemente, dos principais contra indícios, no âmbito dos precedentes da Comissão de Valores Mobiliários para apuração da referida prática.

\footnotetext{
${ }^{1}$ PARENTE, Norma Jonssen. Tratado de Direito Empresarial - Volume VI-Mercado de Capitais. São Paulo, Editora Revistas dos Tribunais Ltda., 2016. Edição Thomson Reuters. Item 10.11 - Uso de informação privilegiada - insider trading. p. 1.
} 
Para tanto, iniciaremos com o Capítulo 1 intitulado Insider Trading. Após breve relato acerca da importância da regulamentação da informação no mercado de capitais, serão analisados os dispositivos legais e regulamentares que fundamentam a responsabilização da referida infração. Em seguida, apresentaremos quem pode cometer a prática de insider trading, inclusive, diferenciando insider primário e insider secundário, tendo em vista a legislação aplicável a cada uma dessas espécies de insider e as presunções construídas pela Comissão de Valores Mobiliários.

Ainda, exploraremos o conceito de insider trading, destrinchando cada um dos elementos que configuram a prática de acordo com o entendimento consolidado da Comissão de Valores Mobiliários. Por fim, será necessário verificar a responsabilidade daquele que pratica o ato nas esferas cível, penal e administrativa.

Finalizadas as considerações a respeito das questões relevantes do uso indevido de informações privilegiadas, seguiremos para a análise da prova indiciária no Capítulo 2, denominado Considerações sobre a Prova Indiciária. Após uma breve introdução do Capítulo 2, será apresentado o conceito da prova indiciária e sua validade como qualquer outro meio de prova.

Posteriormente, verificaremos o entendimento da Comissão de Valores Mobiliários sobre a utilização de prova indiciária para justificar a condenação por infrações administrativas, destacando precedentes relacionados com o uso indevido de informações privilegiadas. Também serão apresentados outros precedentes, ainda que no âmbito do Poder Judiciário, que contribuam para a construção do posicionamento da Comissão de Valores Mobiliários.

Passadas todas estas questões preliminares, mas de necessário endereçamento, partiremos para o Capítulo 3, denominado Indícios e Contra Indícios da Prática de Insider Trading. Nesse Capítulo, primeiro será apresentada uma lógica comum aos indícios presente nos precedentes de 
insider trading, nos quais a prova indiciária foi utilizada para fundamentar a decisão.

Em seguida, será feita uma exposição dos usuais indícios e contra indícios considerados no âmbito de julgamento de Processo Sancionador pelo Colegiado da Comissão de Valores Mobiliários, para fundamentar a condenação ou absolvição dos acusados pelo uso indevido de informação privilegiada.

Por fim, cabe ressaltar que o presente trabalho não ambiciona formar juízo de adequação em relação à condenação ou absolvição da prática de insider trading nos precedentes da Comissão de Valores Mobiliários. Destina-se, exclusivamente, a apresentar os principais indícios e contra indícios consideradas nos referidos julgamentos pelo Colegiado da Comissão de Valores Mobiliários para fundamentar as decisões. 


\section{INSIDER TRADING}

\subsection{Regulamentação da Informação no Mercado de Capitais}

A relevância da regulamentação da informação no mercado de capitais é irrefutável como meio eficaz para a proteção do investidor, ao passo que possibilita que este tome suas decisões de investimento de forma racional, pelo menos em tese ${ }^{2}$.

É evidente que essa regulamentação não protege o investidor contra os riscos intrínsecos do mercado, ou seja, não garante que um investimento será bem-sucedido. No entanto, assegura a divulgação de informações necessárias para a tomada de decisão consciente pelo público em geral ${ }^{3}$. Mais do que isso, permite que os investidores estejam em pé de igualdade na negociação de valores mobiliários, já que todos têm acesso às mesmas informações e, ainda, coíbe práticas como manipulação de mercado e uso indevido de informações privilegiadas na negociação de valores mobiliários.

Os investidores do mercado de capitais estão a mercê das informações divulgadas pelos integrantes do sistema de distribuição de valores mobiliários, em especial, as companhias abertas. A título de curiosidade, José Martins Proença estabelece um paralelo entre a condição do investidor no mercado de capitais e a condição do consumidor, como parte vulnerável nas relações contratuais do mercado de bens e serviços ${ }^{4}$.

\footnotetext{
${ }^{2}$ PROENÇA, José Marcelo Martins. Insider Trading - regime jurídico do uso de informações privilegiadas no mercado de capitais. São Paulo: Quartier Latin, 2005. p. 134.

${ }^{3}$ Instituto Brasileiro de Relações com Investidores e Comissão de Valores Mobiliários. Relações com Investidores da Pequena Empresa ao Mercado de Capitais. Disponível em: $<$ http://www.portaldoinvestidor.gov.br/portaldoinvestidor/export/sites/portaldoinvestidor/publicac ao/Livro/Livro-IBRI-CVM.pdf>. Acesso em: 03.09.2017.

${ }^{4}$ PROENÇA, José Marcelo Martins. Insider Trading - regime jurídico do uso de informações privilegiadas no mercado de capitais. p. 135.
} 
Assim, a regulamentação da informação no mercado de capitais tem como intuito a divulgação de informações completas e corretas destinadas aos investidores, inclusive, para que os emissores de valores mobiliários, e pessoas a eles relacionadas, não possam tirar vantagem de sua posição forte na relação e se aproveitar de investidores propositalmente desinformados.

Além da proteção dos investidores, a existência de normas regulamentando a divulgação e utilização da informação tem como objetivo proteger a existência do mercado de valores mobiliários, bem como sua credibilidade e eficiência.

Uma das consequências mais devastadoras de práticas como manipulação de mercado e, mais especificamente, da negociação de valores mobiliários com a utilização de informações privilegiadas é o impacto na confiança dos investidores no mercado de capitais. Como, inclusive, afirmado pelo professor Francisco Müssnich, "a confiança dos investidores foi e é elemento essencial no processo de formação e consolidação do mercado de valores mobiliários" e manutenção dessa confiança é "tarefa crucial para o desenvolvimento desse mercado" ${ }^{5}$.

O investidor prejudicado pela ocorrência de práticas não equitativas perde a confiança no mercado de valores mobiliários. É evidente que uma pessoa que não confia no sistema de distribuição de valores mobiliários de um país, não vai investir suas economias no mesmo. Ainda assim, como instrumento de canalização da poupança do público em geral, o mercado de capitais depende dessa aplicação de recursos financeiros diretamente por investidores. Então, sem credibilidade, não há investidores e, sem investidores, não há recursos financeiros suficientes para sustentar o mercado de capitais do país.

\footnotetext{
5 MÜSSNICH, Francisco Antunes Maciel. O insider trading no direito brasileiro. São Paulo: Saraiva, 2017. p. 28.
} 
Além disso, a eficiência do mercado de valores mobiliários está intrinsicamente conectada a capacidade deste de assegurar a determinação legítima do preço dos valores mobiliários negociados, que através da simetria informal do público em geral, deverá refletir corretamente as informações disponíveis aos investidores ${ }^{6}$.

A negociação de valores mobiliários com a utilização de informações privilegiadas, o uso de práticas não equitativas e outras práticas de manipulação de mercado, afetam diretamente essa capacidade do mercado de capitais de construir preços legítimos. Nesse sentido, essas práticas desestabilizam o mercado de valores mobiliários, lesionando sua eficiência.

Ainda mais, o mercado de capitais desempenha um importante papel no desenvolvimento econômico do país. Dessa forma, e em razão do evidente interesse público envolvido, a existência de normas capazes de estabelecer e manter um ambiente de negociação confiável e eficiente é imprescindível para a estabilidade econômica do país. Ou seja, o objeto jurídico imediato a ser tutelado com a regulamentação da informação e a proibição de práticas de manipulação de mercado e insider trading é a estabilidade e o funcionamento do mercado de capitais - e, em última análise, o objeto jurídico mediato é proteção da estabilidade e desenvolvimento econômico do país.

Enfim, a regulamentação da informação tem como intuito proteger não apenas os investidores, mas também o próprio mercado de capitais, sua credibilidade e eficiência, que possuem impacto direto na economia do país.

\footnotetext{
${ }^{6}$ PROENÇA, José Marcelo Martins. Insider Trading - regime jurídico do uso de informações privilegiadas no mercado de capitais. p. 167.
} 


\subsection{Direito}

\subsubsection{Panorama Legislativo}

Para o entendimento do regime jurídico da prática de insider trading, no presente item serão apresentadas as principais normas que regulamentam o tema no ordenamento brasileiro.

Nesse ponto, cabe esclarecer que o Brasil foi um dos primeiros a fazer menção à prática de insider trading em sua legislação. Enquanto no Brasil, o tema foi abordado (ainda que não devidamente regulamentado), inicialmente, na Lei no 4.728, de 14 de julho de 1965 (“Lei no 4.728”), na maioria dos países a legislação sobre a utilização indevida de informações privilegiadas somente foi editada na década de 1990, como esclarece José Martins Proença:

(...) constatamos que a média de entrada em vigor de legislação sobre insider trading, nos países desenvolvidos, acha-se realmente situada na década de 1990, o que posiciona muito bem a legislação brasileira, pois, antes mesmo de 1976, quando da implementação da LSA, nosso legislador já havia se preocupado com o assunto, ao elaborar a Lei $n^{\circ} 4.728$, de 1965 (LMC) ${ }^{7}$.

Como mencionado acima, a Lei $\mathrm{n}^{\circ} 4.728$, artigo 10, inciso X, contém a primeira referência, na legislação brasileira, ao uso indevido de informações relevantes não divulgadas ao mercado, ao atribuir ao Banco Central a competência de "fiscalizar a utilização de informações não divulgadas ao público em benefício próprio ou de terceiros, por acionistas ou pessoas que, por força de cargos que exerçam, a elas tenham acesso"».

De início, cabe notar que o referido dispositivo é anterior a criação da própria Comissão de Valores Mobiliários, autarquia federal responsável pela fiscalização do mercado de capitais - e, consequentemente, atual

\footnotetext{
${ }^{7}$ PROENÇA, José Marcelo Martins. Insider Trading - regime jurídico do uso de informações privilegiadas no mercado de capitais. p. 205

8 BRASIL. Lei $n^{o}$ 4.728, de 14 de julho de 1965. Disponível em: <http://www.planalto.gov.br/ccivil 03/leis/L4728.htm>. Acesso em: 09.09.2017.
} 
responsável pela investigação e responsabilização administrativa pela prática de insider trading.

Além disso, outros fatores, como a ausência de regras regulando essa fiscalização, impediram que a partir do dispositivo ora comentado fosse possível refrear a prática de insider trading, ou até mesmo responsabilizar aqueles que negociavam utilizando-se de informações privilegiadas. Nas palavras de Francisco Müssnich:

\begin{abstract}
Apesar de a norma sinalizar um primeiro esforço do legislador no combate ao insider trading, é flagrante sua deficiência, ou simplesmente sua insuficiência para fazer frente a tão importante questão. Essa regra, até então ainda isolada no sistema jurídico brasileiro, não tornava crime, nem ato ilícito, o uso indevido de informação privilegiada. Da redação, pode-se dizer, até simples, o dispositivo também não oferecia qualquer parâmetro para a caracterização do insider trading. Nesse sentido, justifica-se a crítica de Fábio Konder Comparato, ao afirmar que uma norma que atribui competência fiscalizatória requer a existência de outras regras que disciplinem o tema, bem como de um sistema adequado de sanções para garantir a repressão da prática ${ }^{9}$.
\end{abstract}

Com a edição da Lei no 6.404, de 15 de dezembro de 1976 ("Lei n 6.404"), a negociação de valores mobiliários com o uso indevido de informação privilegiada ganhou regulamentação mais consistente e completa consubstanciada nos parágrafos do artigo 155 da Lei $n^{\circ} 6.404$.

O referido dispositivo é responsável pela instituição e regulamentação do dever de lealdade dos administradores da companhia. A prática de insider trading, prevista neste dispositivo, constitui clara quebra do dever de lealdade do administrador da companhia, quando por este praticada. Nesse sentido, o parágrafo $1^{\circ}$ do artigo 155 , introduz o dever dos administradores de guardar sigilo sobre informações ainda não divulgadas ao mercado, bem como, a vedação da prática de insider trading:

Cumpre, ademais, ao administrador de companhia aberta, guardar sigilo sobre qualquer informação que ainda não tenha sido divulgada para conhecimento do mercado, obtida em razão do cargo e capaz de influir de modo ponderável na cotação de valores mobiliários, sendo-lhe vedado valer-se da informação para

\footnotetext{
${ }^{9}$ MÜSSNICH, Francisco Antunes Maciel. O insider trading no direito brasileiro. p. 23.
} 
obter, para si ou para outrem, vantagem mediante compra ou venda de valores mobiliários ${ }^{10}$.

Em relação ao dever de guardar sigilo, como textualmente expresso, é necessário o atendimento de duas condições: (i) o acesso a informação em decorrência do cargo de administrador da companhia; e (ii) a informação ser capaz de influir de modo ponderável na cotação dos valores mobiliários afetados por tal informação.

Já o parágrafo $2^{\circ}$ do artigo $155^{11}$, incumbi ao administrador da companhia o dever adicional de cuidado para que seus subordinados e terceiros de confiança guardem sigilo das informações relevantes não divulgadas ao mercado e não negociem na posse dessas informações.

O parágrafo $3^{\circ}$ do artigo $155^{12}$, por sua vez, estabelece o direito à reparação civil pelos prejuízos causados ao investidor em razão da negociação com insider. Esse dispositivo cria, ainda, uma exceção: não haverá qualquer reparação quando a negociação ocorrer entre insiders.

Pela clara interpretação teleológica da norma, inclusive como já exposto no presente, o objetivo da vedação da negociação de valores mobiliários com a utilização de informações privilegiadas é evitar que no momento da negociação de valores mobiliários exista assimetria informacional entre os participantes da transação. Ora, se ambas as partes da negociação tiveram acesso a mesma informação relevante não divulgada ao mercado, não há que se falar em assimetria informal e, consequentemente, em obrigação de indenizar.

10 BRASIL. Lei $n^{o}$ 6.404, de 15 de dezembro de 1976. Disponível em: <http://www.planalto.gov.br/ccivil_03/leis/L6404consol.htm>. Acesso em: 09.09.2017.

11 Artigo 155. (...) $\S 2^{\circ}$ : “O administrador deve zelar para que a violação do disposto no $\S 1^{\circ}$ não possa ocorrer através de subordinados ou terceiros de sua confiança".

12 Artigo 155. (...) $§ 3^{\circ}$ : “É vedada a utilização de informação relevante ainda não divulgada, por qualquer pessoa que a ela tenha tido acesso, com a finalidade de auferir vantagem, para si ou para outrem, no mercado de valores mobiliários". 
Posteriormente, com o advento da Lei $\mathrm{n}^{\mathrm{o}} 10.303$, de 31 de outubro de 2001 ("Lei n ${ }^{\circ} 10.303$ "), foi incluído o parágrafo $4^{\circ}$ no artigo 155, da Lei $n^{\circ}$ 6.404, com a seguinte redação: "É vedada a utilização de informação relevante ainda não divulgada, por qualquer pessoa que a ela tenha tido acesso, com a finalidade de auferir vantagem, para si ou para outrem, no mercado de valores mobiliários"13.

Nos termos desse dispositivo, a vedação da prática de insider trading foi ampliada para prever que qualquer pessoa que negociar com o uso indevido de informação privilegiada poderá ser responsabilizada, e não apenas aqueles com acesso a informação em razão de cargo, função ou posição na companhia.

Além disso, a Lei no 10.303 também foi responsável pela tipificação penal do "uso indevido de informação privilegiada" ao acrescentar o artigo 27-D na Lei n 6.385, de 7 de dezembro de 1976 (“Lei n ${ }^{\circ} 6.385$ ”):

Utilizar informação relevante ainda não divulgada ao mercado, de que tenha conhecimento e da qual deva manter sigilo, capaz de propiciar, para si ou para outrem, vantagem indevida, mediante negociação, em nome próprio ou de terceiro, com valores mobiliários ${ }^{14}$.

A tipificação penal da prática de insider trading, e demais crimes contra o mercado de capitais, comprova a relevância atribuída à proteção do mercado de capitais e do sistema de distribuição de valores mobiliários do país como um todo.

Nos termos desse dispositivo se enquadrada no tipo penal insider trading a "conduta de quem utiliza informação relevante, ainda não

13 BRASIL. Lei $n^{o}$ 6.404, de 15 de dezembro de 1976. Disponível em: <http://www.planalto.gov.br/ccivil 03/leis/L6404consol.htm>. Acesso em: 09.09.2017.

14 BRASIL. Lei $n^{o}$ 10.303, de 31 de outubro de 2001. Disponível em: <http://www.planalto.gov.br/ccivil_03/leis/LEIS_2001/L10303.htm\#art27f >. Acesso em: 06.12 .2017 . 
divulgada ao mercado, da qual deve guardar sigilo, para negociar com valores mobiliários" $"$.

Pela clara redação desse dispositivo, "o delito é próprio, uma vez que somente podem ser punidos aqueles obrigados a guardar sigilo, como são: os administradores, membros do conselho fiscal, o acionista controlador" ${ }^{\prime 16}$. Ou seja, diferentemente do ilícito administrativo, não é qualquer pessoa que podia ser penalmente responsabilizada pela prática de insider trading.

Ainda assim, cabe notar que a tipificação penal do uso indevido de informações privilegiadas foi alterada, recentemente, pela Lei $\mathrm{n}^{\circ} 13.506$, de novembro de 2017 ("Lei no 13.506").

Se antes havia incerteza sobre a possível responsabilização penal do insider secundário, com o advento da Lei n ${ }^{\circ} 13.506$, não restam dúvidas. Com a retirada do termo "da qual deva manter sigilo" para a configuração do tipo penal de insider trading, não há mais limitação do agente ativo do crime, conforme se depreende da nova redação do artigo 27-D, caput, da Lei ${ }^{\circ}$ 13.506:

Utilizar informação relevante de que tenha conhecimento, ainda não divulgada ao mercado, que seja capaz de propiciar, para si ou para outrem, vantagem indevida, mediante negociação, em nome próprio ou de terceiros, de valores mobiliários: Pena - reclusão, de 1 (um) a 5 (cinco) anos, e multa de até 3 (três) vezes o montante da vantagem ilícita obtida em decorrência do crime ${ }^{17}$.

Assim, para fatos ocorridos a partir da publicação da Lei nº 13.506 (dia 14 de novembro de 2017), a negociação de valores mobiliários com a utilização de informações privilegiadas constitui ilícito penal, passível de

\footnotetext{
${ }^{15}$ EIZIRIK, Nelson. A lei das S/A Comentada. Volume III. $2^{\mathrm{a}}$ edição. São Paulo: Quartier Latin, 2015. p. 146.

${ }^{16}$ EIZIRIK, Nelson. A lei das S/A Comentada.p. 146.

17 BRASIL. Lei $n^{o}$ 6.385, de 07 de dezembro de 1976. Disponível em: <https://www.planalto.gov.br/ccivil_03/leis/L6385.htm>. Acesso em: 06.12.2017.
} 
responsabilização, tanto quando realizada por insider primário como quando realizada por insider secundário.

Além disso, nos termos do 27-D, parágrafo $1^{\text {o }}$, da Lei n ${ }^{\circ} 13.506$, a prática de repasse de "informação sigilosa relativa a fato relevante a que tenha tido acesso em razão de cargo ou posição que ocupe em emissor de valores mobiliários ou em razão de relação comercial, profissional ou de confiança com o emissor" 18 foi penalmente tipificada.

Como fica claro pela redação do dispositivo, apenas pessoas que tenham conhecimento da informação em razão de sua função (seja insider primário propriamente dito ou insider temporário) podem ser penalmente responsabilizados pelo repasse de informações - o que está em linha com o artigo 155 , parágrafo $1^{\circ}$, da Lei $\mathrm{n}^{\circ}$ 6.404/1976, que já possibilitava a responsabilização do informante, pela via administrativa.

\subsubsection{Regulamentação da Comissão de Valores Mobiliários}

A primeira norma editada pela Comissão de Valores Mobiliários relacionada com a vedação da negociação de valores mobiliários com o uso indevido de informação privilegiada, foi a Instrução CVM n ${ }^{\circ} 31$, de 8 de fevereiro de 1984 (“Instrução CVM n 31 ”), em seu artigo 10 e seguintes ${ }^{19}$.

18 BRASIL. Lei $n^{o}$ 6.385, de 07 de dezembro de 1976. Disponível em: $<$ https://www.planalto.gov.br/ccivil_03/leis/L6385.htm>. Acesso em: 06.12.2017.

19 Artigo 10: "É vedado aos administradores e acionistas controladores de companhia aberta valerem-se de informação à qual tenham acesso privilegiado, relativa a ato ou fato relevante ainda não divulgado ao mercado, nos termos dos artigos $2^{\circ}$ e $7^{\circ}$ desta Instrução, para obter, para si ou para outrem, vantagem mediante negociação com valores mobiliários".

Artigo 11: “É vedada, como prática não eqüitativa, a negociação com valores mobiliários realizada por quem quer que, em virtude de seu cargo, função ou posição, tenha conhecimento de informação relativa a ato ou fato relevante antes de sua comunicação e divulgação ao mercado".

Parágrafo único: "A mesma vedação aplica-se a quem quer que tenha conhecimento de informação referente a ato ou fato relevante, sabendo que se trata de informação privilegiada ainda não divulgada ao mercado".

Artigo 12: "Cabe, ainda, aos administradores zelar para que subordinados e terceiros de sua confiança: I - guardem sigilo sobre informações relativas a ato ou fato relevante às quais tenham 
Essa Instrução CVM n 31 foi considerada um grande avanço na regulamentação do insider trading, ao passo que ampliou "o elenco dos insiders para abranger a própria companhia, o acionista controlador, ou aqueles que, em virtude de cargo, posição ou função, têm acesso a informação relativa a ato ou fato relevante" ${ }^{20}$ - mesmo antes da ampliação do o conceito de sujeito ativo da prática de insider trading com a promulgação da Lei $n^{\circ} 10.303$.

Atualmente, a Instrução CVM no 358, de 3 de janeiro de 2002 ("Instrução CVM n 358 "), que revogou a Instrução CVM n 31, regulamenta a "divulgação e uso de informações sobre ato ou fato relevante" e "estabelece vedações e condições para a negociação de ações de companhia aberta na pendência de fato relevante não divulgado ao mercado" 21 .

Nesse sentido, o artigo 13 da Instrução CVM n 358 prevê a vedação da negociação de valores mobiliários na pendência de divulgação de fato relevante, bem como, institui outras vedação e condições para a negociação de valores mobiliários emitidos por companhias abertas.

Assim como a Lei $\mathrm{n}^{\circ}$ 6.404, a vedação da prática de insider trading abrange tanto pessoa que tenha conhecimento da informação em razão de cargo, função ou posição em companhia aberta (caput $)^{22}$, como qualquer

acesso privilegiado; II - não se utilizem daquelas informações para obter, para si ou para outrem, vantagem mediante negociação com valores mobiliários".

${ }^{20}$ EIZIRIK, Nelson. A lei das S/A Comentada.p. 142.

${ }^{21}$ COMISSÃO DE VALORES MOBILIÁRIOS. Instrução CVM no 358, de 3 de janeiro de 2002. Disponível <http://www.cvm.gov.br/export/sites/cvm/legislacao/instrucoes/anexos/300/inst358consolid.pdf $>$. Acesso em: 09.09.2017.

${ }^{22}$ Artigo 13: "Antes da divulgação ao mercado de ato ou fato relevante ocorrido nos negócios da companhia, é vedada a negociação com valores mobiliários de sua emissão, ou a eles referenciados, pela própria companhia aberta, pelos acionistas controladores, diretos ou indiretos, diretores, membros do conselho de administração, do conselho fiscal e de quaisquer órgãos com funções técnicas ou consultivas, criados por disposição estatutária, ou por quem quer que, em virtude de seu cargo, função ou posição na companhia aberta, sua controladora, suas controladas ou coligadas, tenha conhecimento da informação relativa ao ato ou fato relevante". 
outra pessoa que tenha conhecimento da informação ainda não divulgada ao mercado (parágrafo primeiro) ${ }^{23}$.

De todo modo, o artigo 13 da Instrução CVM no 358 , mesmo detalhando as hipóteses de vedação da negociação de valores mobiliários com a utilização de informações relevantes não divulgadas ao mercado em seus demais parágrafos, não inova em relação ao artigo 155 da Lei no 6.404 .

\section{3. $\quad 0$ Insider Trader}

\subsubsection{Quem pode ser Insider?}

Tanto a Lei n ${ }^{\circ} 6.404$ como a Instrução CVM no 358 não definiram quem é o insider trader ${ }^{24}$. Ou seja, a negociação de valores mobiliários com o uso indevido de informações privilegiadas pode ser cometida por qualquer pessoa que tenha acesso a tais informações.

Na prática, o insider pode ser qualquer um que esteja em situação privilegiada perante outras pessoas de interesses econômicos, em tese, idênticos - em razão do acesso a informação relevante não divulgada ao mercado. Lembrando, ainda, que essa situação privilegiada do insider, por si só, não apresenta qualquer caráter ilícito ${ }^{25}$.

$\mathrm{Na}$ jurisprudência norte americana ${ }^{26}$, existe $\mathrm{o}$ entendimento consolidado no sentido de que para a responsabilização pela prática de

\footnotetext{
23 Artigo 13. (...) $\S 1^{\circ}$ : “A mesma vedação aplica-se a quem quer que tenha conhecimento de informação referente a ato ou fato relevante, sabendo que se trata de informação ainda não divulgada ao mercado, em especial àqueles que tenham relação comercial, profissional ou de confiança com a companhia, tais como auditores independentes, analistas de valores mobiliários, consultores e instituições integrantes do sistema de distribuição, aos quais compete verificar a respeito da divulgação da informação antes de negociar com valores mobiliários de emissão da companhia ou a eles referenciados".

${ }^{24}$ PARENTE, Norma Jonssen. Tratado de Direito Empresarial - Volume VI-Mercado de Capitais. p. 10.

${ }^{25}$ CARVALHOSA, Modesto. Comentários à lei de sociedades anônimas. Volume 3. $6^{\mathrm{a}}$ edição. São Paulo: Saraiva, 2014. p. 436.

${ }^{26}$ Caso Chiarella v. U.S. 222 (1980). O acusado era funcionário de gráfica responsável pela impressão de prospectos e outros documentos assemelhados e tinha acesso a informações sobre
} 
insider trading é necessário que o acusado possua dever fiduciário para com relação a companhia - mesmo que tal dever tenha sido adquirido de terceiro, pois é elemento essencial para a configuração do ilícito insider trading a existência do dever fiduciário do agente perante a companhia emissora de valores mobiliários ${ }^{27}$.

Já no Brasil, independentemente de relacionamento direto ou não com a companhia e da existência ou não de dever fiduciário perante a mesma, o insider pode ser qualquer pessoa que obteve acesso à informação relevante ainda não divulgada ao mercado.

Seja quando o acesso é decorrente "de seu cargo, função ou posição na companhia aberta, sua controladora, suas controladas ou coligadas" 28 , como acontece com os membros da administração, acionistas controladores e prestadores de serviço da companhia, ou quando é decorrente de qualquer outro meio, como, por exemplo, relações de parentesco e amizade.

Como exemplifica Modesto Carvalhosa, podem ser insiders traders tanto pessoas que possuem relação direta com a companhia, quanto qualquer outro participante do mercado de capitais que tiver acesso à informação privilegiada, como: (i) os administradores da companhia; (ii) os membros de quaisquer órgãos criados pelo estatuto da companhia com funções técnicas ou destinadas a aconselhar os administradores; (iii) os membros do conselho fiscal; (iv) as pessoas autônomas que prestam serviços profissionais à companhia; as pessoas com relação de subordinação ou que sejam empregados da companhia, e que tenham acesso às informações

ofertas de valores mobiliários que iriam ocorrer. Com base em tais informações, adquiria ações de emissoras anres de ofertas, beneficiando-se de sua valorização.

${ }^{27}$ BARBOSA, Marcelo. Algumas notas sobre insider trading. IN: VENANCIO FILHO, Alberto; LOBO, Carlos Augusto Silveira; ROSMAN, Luiza Alberto Colonna. LEI das S.A. em seus 40 anos. Rio de Janeiro: Forense, 2017. p. 287.

${ }^{28}$ COMISSÃO DE VALORES MOBILIÁRIOS. Instrução CVM n ${ }^{\circ}$ 358, de 3 de janeiro de 2002. Disponível em: Disponível em: <http://www.cvm.gov.br/legislacao/instrucoes/inst358.html>. Acesso em: 09.09.2017. 
privilegiadas; (v) os controladores com acesso às informações privilegiadas da administração da companhia; (vi) os intermediários do mercado de capitais, dentre eles, as instituições componentes do sistema de distribuição de valores mobiliários, bem como pessoas físicas que as administram, nelas trabalham ou delas são agentes autônomos; e (vii) os investidores ou participantes do mercado, na qualidade de compradores e vendedores de valores mobiliários ali negociados ${ }^{29}$.

\subsubsection{Insider Primário e Insider Secundário}

Após listar potenciais insiders, é necessário diferenciar insiders primários e insiders secundários, bem como apresentar as relevantes disparidades entre eles no âmbito de Processos Sancionadores.

O insider primário é aquele que obtém acesso à informação relevante não divulgada ao mercado em razão de (i) sua posição funcional na companhia, como ocorre com os administradores, (ii) sua participação acionária na condição de acionista controlador, (iii) sua função ou posição na controladora, controladas ou coligadas da companhia, dentre outros. Em resumo, os insiders primários (também conhecidos como insiders institucionais) "recebem, diretamente, a informação privilegiada de sua fonte e têm o conhecimento especializado suficiente para saber que tal informação é relevante" 30 .

Existe ainda o insider temporário, que é uma espécie de insider primário. Essa espécie de insider foi criada para "designar a categoria de profissionais que, muito embora não sejam empregados ou administradores, possuam uma relação fiduciária com a companhia", decorrentes de função,

\footnotetext{
${ }^{29}$ CARVALHOSA, Modesto. Comentários à lei de sociedades anônimas. p. 438.

${ }^{30}$ EIZIRIK, Nelson; GAAL, Ariádna B.; PARENTE, Flávia; HENRIQUES, Marcus de Freitas. Mercado de capitais - regime jurídico. $3^{\text {a }}$ edição. Rio de Janeiro: Renovar, 2011. p. 564.
} 
como por exemplo, prestador de serviço da companhia, "que lhes confira acesso direto às informações" ${ }^{\prime 1}$.

Bom, os insiders temporários, assim como os insiders primários, possuem acesso à informação diretamente da fonte - e, nesse sentido, os insiders temporários são equiparados aos insiders primários no âmbito de Processo Administrativo Sancionador ("PAS" ou "Processo Sancionador") instaurado pela Comissão de Valores Mobiliários, inclusive, como é possível extrair do parágrafo $1^{\circ}$ do artigo 13 da Instrução da CVM n ${ }^{\circ} 358$ (com grifos):

$\S 1^{\circ}$ A mesma vedação aplica-se a quem quer que tenha conhecimento de informação referente a ato ou fato relevante, sabendo que se trata de informação ainda não divulgada ao mercado, em especial àqueles que tenham relação comercial, profissional ou de confiança com a companhia, tais como auditores independentes, analistas de valores mobiliários, consultores e instituições integrantes do sistema de distribuição, aos quais compete verificar a respeito da divulgação da informação antes de negociar com valores mobiliários de emissão da companhia ou a eles referenciados ${ }^{32}$.

Ainda assim, importante lembrar que o insider temporário é marcado por sua volatilidade, ou como o próprio nome demonstra, pela sua temporariedade. Dessa forma, diferentemente do insider primário típico, é necessário comprovar a forma e o momento da obtenção da informação, para a caracterização (ou não) daquele que negociou com valores mobiliários da companhia como insider primário $^{33}$.

Os insiders secundários, por sua vez, são todos aqueles que recebem as informações privilegiadas através dos insiders primários, de outras pessoas que repassaram a informação ou de qualquer outro meio. Além disso, o insider secundário (comumente denominado tippee) não está obrigado a guardar sigilo das informações privilegiadas das quais tenha conhecimento

\footnotetext{
${ }^{31}$ MÜSSNICH, Francisco Antunes Maciel. O insider trading no direito brasileiro. p. 45.

${ }^{32}$ COMISSÃO DE VALORES MOBILIÁRIOS. Instrução CVM no 358, de 3 de janeiro de 2002. Disponível em: Disponível em: 〈http://www.cvm.gov.br/legislacao/instrucoes/inst358.html>. Acesso em: 09.09.2017.

${ }^{33}$ MÜSSNICH, Francisco Antunes Maciel. O insider trading no direito brasileiro. p. 46.
} 
e, algumas vezes, sequer sabe que tais informações são relevantes para a companhia.

Nesse ponto, cabe lembrar que de acordo com o entendimento consolidado da Comissão de Valores Mobiliários existem três presunções que afetam os denominados insiders primários, conforme esclarecido no voto do Diretor Roberto Tadeu Fernandes no PAS CVM nº 15/2010: (i) presunção de que em certos períodos há informação privilegiada, sendo vedada a negociação com valores mobiliários da companhia; (ii) presunção de conhecimento da informação relevante ainda não divulgada ao mercado; e (iii) presunção de que, ao negociar com valores mobiliários da companhia na posse de informação privilegiada, os insiders primários atuam com a intenção de auferir vantagem indevida ${ }^{34}$.

A primeira presunção está disposta no artigo 13, caput e parágrafos $3^{\circ}$ e $4^{\circ}$, da Instrução CVM no 358 , mas será descrita apenas no próximo item - ao analisar a existência de informação relevante não divulgada ao mercado como elemento caracterizador da prática do ilícito insider trading.

Já a segunda presunção juris tantum construída nos julgamentos de casos de insider trading estabelece que os insiders primários, em razão da posição que ocupam na administração da companhia, têm acesso à informação relevante não divulgada ao mercado ${ }^{35}$.

É fato que a aplicação ou não da presunção mencionada deve ser analisada caso a caso, principalmente, no contexto atual dos órgãos de administração das grandes companhias abertas, sendo necessário analisar a

\footnotetext{
${ }^{34}$ Extrato da Sessão de Julgamento do Processo Administrativo Sancionador CVM no 15/2010. Diretor-Relator: Roberto Tadeu Antunes Fernandes. Presidente da sessão de julgamento: Leonardo P. Gomes Pereira. Data de Julgamento: 08.12.2015. Disponível em: $<$ http://www.cvm.gov.br/export/sites/cvm/sancionadores/sancionador/anexos/2015/20151208 PA S 152010.pdf>. Acesso em: 15.09.2017.

${ }^{35}$ EIZIRIK, Nelson. A lei das S/A Comentada. p. 146.
} 
posição de cada administrador, inclusive, vis-à-vis suas funções previstas no estatuto social da companhia.

De acordo com a terceira presunção, sempre que um insider primário negocia com valores mobiliários na posse de informação relevante não divulgada ao mercado, o faz com a intenção de auferir vantagem indevida.

Nesse ponto, conclui o Diretor Pablo Renteria, no âmbito do PAS CVM nº RJ2011/3823, que, com relação aos insiders temporários, não se opera a presunção do acesso a informação (que deverá ser devidamente comprovado), mas, uma vez comprovado o acesso a informação, aplica-se a presunção da intenção de obter vantagem indevida (com grifos):

Nessa direção, o que o mencionado art. 13 faz é esclarecer que a relação mais ou menos estreita mantida pelo acusado com a companhia à época dos fatos autoriza a presunção de determinados fatos que integram a configuração da prática de insider trading.

(...)

Como se depreende da leitura do dispositivo, em relação a essas pessoas, admitese a presunção do elemento subjetivo da infração, mas não da ciência da informação relativa ao fato relevante. Compete, portanto, à acusação demonstrar este elemento da infração por meio de provas (diretas ou indiretas) adicionais, como, por exemplo, a evidência de que o departamento ou setor no qual o investigado atuava na companhia ou em outra sociedade do grupo estava diretamente envolvido na operação, que seria objeto de fato relevante ${ }^{36}$.

Enfim, se um administrador da companhia, ou qualquer outra pessoa considerada como insider primário, negociar na pendência de divulgação de informação relevante, a Comissão de Valores Mobiliários entende que dois dos quatro elementos necessários para a caracterização do ilícito insider trading podem ser presumidos pela acusação.

36 Extrato da Sessão de Julgamento do Processo Administrativo Sancionador CVM $\mathrm{n}^{\circ}$ RJ2011/3823. Diretor-Relator: Pablo Renteria. Presidente da sessão de julgamento: Leonardo P. Gomes Pereira. Data de Julgamento: 09.12.2015. Disponível em: <http://www.cvm.gov.br/export/sites/cvm/sancionadores/sancionador/anexos/2015/20151209_PA S_RJ20113823.pdf >. Acesso em: 10.10.2017. 
Naturalmente, e nas palavras do Diretor Relator Roberto Tadeu Fernandes no âmbito do PAS CVM n 15/2010: "tais presunções são relativas e admitem prova em contrário, cabendo ao acusado o ônus de apresentar evidências capazes de comprovar a regularidade de sua conduta e afastar as referidas presunções" ${ }^{\prime 3}$.

Nesse caso, ao invés da acusação comprovar que o acusado estava na posse de informação privilegiada e que negociou com a intenção de obter vantagem, este que precisará apresentar provas suficientes para desconstruir tais presunções.

É evidente que quando o investigado é insider de mercado, como tais presunções não se operam, é necessária a efetiva apresentação de provas pela acusação, do conhecimento da informação relevante não divulgada ao mercado e da intenção de obter vantagem indevida na negociação de valores mobiliários da companhia.

Outra clássica diferença, é que somente a conduta do insider primário se enquadra no tipo penal previsto no artigo 27-D da Lei no 6.385 (com a redação derivada da Lei $n^{\circ}$ 10.303). Nesse sentido, o tipo penal descrito no dispositivo mencionado estabelecia que apenas pode ser sujeito ativo aquele que negocia utilizando-se de informação privilegiada, da qual deva guardar sigilo. Se somente insiders primários possuem o dever de guardar sigilo, é fato que somente eles podiam ser penalmente responsabilizados nos termos do referido dispositivo.

Como já mencionado, a clássica diferença descrita no parágrafo acima foi superada com a promulgação da Lei $\mathrm{n}^{\circ} 13.506$, que alterou a

\footnotetext{
${ }^{37}$ Extrato da Sessão de Julgamento do Processo Administrativo Sancionador CVM no 15/2010. Diretor-Relator: Roberto Tadeu Antunes Fernandes. Presidente da sessão de julgamento: Leonardo P. Gomes Pereira. Data de Julgamento: 08.12.2015. Disponível em: <http://www.cvm.gov.br/export/sites/cvm/sancionadores/sancionador/anexos/2015/20151208_PA $\underline{\mathrm{S} \_152010 . \mathrm{pdf}>}$. Acesso em: 15.09.2017.
} 
redação do artigo 27-D da Lei n ${ }^{\circ} 6.385$, retirando a expressão "da qual deva manter sigilo". Bom, se antes somente os insiders primários podiam ser penalmente responsabilizados, pois só eles possuem o dever de guardar sigilo, a retirada da referida expressão demonstra a clara intenção do legislador de tipificar penalmente a conduta do insider secundário.

\subsection{Configuração da Prática de Insider Trading}

Após entender quem pode ser insider, é preciso esclarecer que nem toda negociação realizada por investidor na posse de informação privilegiada constitui ato ilícito e, consequentemente, passível de responsabilização.

Em resumo, e pelo exposto até o momento, a prática de insider trading deve ser entendida como negociação de compra e venda de valores mobiliários realizada por alguém que detinha conhecimento de informações relevantes, no período em que tais informações ainda estavam pendentes de divulgação ao mercado ${ }^{38}$.

Ou seja, o ilícito acontece sempre que um insider (alguém que obteve acesso à informação relevante não divulgada ao mercado) negocia com valores mobiliários da companhia (relacionada com tal informação relevante) no período entre o conhecimento da informação relevante e a divulgação de tal informação e/ou logo após a divulgação da informação pela companhia ao público em geral.

Ainda assim, é necessário que nessa transação estejam presentes determinados elementos para que o ilícito esteja configurado.

Vale lembrar, ainda, que a prática de insider trading somente pode ser averiguada no âmbito de companhias abertas, uma vez que apenas

${ }^{38}$ CARVAlHOSA, Modesto. Comentários à lei de sociedades anônimas. p. 437. 
companhias registradas na Comissão de Valores Mobiliários podem ofertar publicamente valores mobiliários previstos no artigo $2^{\circ}$ da Lei $n^{\circ} 6.385^{39}$.

Bom, de acordo com o entendimento consolidado da Comissão de Valores Mobiliários, a configuração da prática insider trading exige a presença dos seguintes elementos: (i) existência de informação relevante ainda não divulgada ao mercado; (ii) acesso privilegiado a tal informação; (iii) utilização dessa informação na negociação de valores mobiliários; e (iv) intenção de auferir vantagem indevida, para si ou para outrem ${ }^{40}$.

\subsubsection{Informação Relevante não divulgada ao mercado}

Pois bem, pela leitura do primeiro elemento - existência de informação relevante ainda não divulgada ao mercado, é possível extrair que a informação deverá "revestir-se de determinados atributos que justifiquem a severidade do tratamento previsto em lei" ${ }^{41}$.

Primeiramente, é necessária a existência de uma informação razoavelmente precisa e dotada de um mínimo de materialidade. Ou seja, a negociação com base em meros rumores não configura a prática de insider trading.

Por outro lado, de acordo com o entendimento do Colegiado da Comissão de Valores Mobiliários, para a configuração da conduta ilícita, a

\footnotetext{
${ }^{39}$ Artigo 20: "São valores mobiliários sujeitos ao regime desta Lei: I - as ações, debêntures e bônus de subscrição; II - os cupons, direitos, recibos de subscrição e certificados de desdobramento relativos aos valores mobiliários referidos no inciso II; III - os certificados de depósito de valores mobiliários; IV - as cédulas de debêntures; $V$ - as cotas de fundos de investimento em valores mobiliários ou de clubes de investimento em quaisquer ativos; VI - as notas comerciais; VII - os contratos futuros, de opções e outros derivativos, cujos ativos subjacentes sejam valores mobiliários; VIII - outros contratos derivativos, independentemente dos ativos subjacentes; e IX quando ofertados publicamente, quaisquer outros títulos ou contratos de investimento coletivo, que gerem direito de participação, de parceria ou de remuneração, inclusive resultante de prestação de serviços, cujos rendimentos advêm do esforço do empreendedor ou de terceiros".

40 TRINDADE, Marcelo Fernandez. Vedações à Negociação de Valores Mobiliários por Norma Regulamentar: Interpretação e Legalidade. IN: VON ADAMEK, Marcelo Vieira. Temas de Direito Societário e Empresarial Contemporâneos. Malheiros Medidores, 2011. p. 457.

${ }^{41}$ MÜSSNICH, Francisco Antunes Maciel. O insider trading no direito brasileiro. p. 35.
} 
informação privilegiada não precisa ser definitiva, conforme expresso no trecho abaixo do voto do Diretor Pedro Marcilio de Sousa no âmbito do PAS $\mathrm{CVM} \mathrm{n}^{\circ} \mathrm{RJ} 2006 / 5928$ (destacou-se):

Não se exige que a informação seja definitiva ou esteja formalizada para que se considere um fato como relevante e, portanto, sujeito ao dever de divulgação. Basta que a informação não seja meramente especulativa, mera intenção não baseada em fatos concretos ${ }^{42}$.

Além disso, a informação precisa ser relevante. De acordo com o entendimento consolidado da Comissão de Valores Mobiliários, considerase informação relevante àquela capaz de influir na cotação dos valores mobiliários da companhia, ocasionando alta ou queda, após sua divulgação. Como, por exemplo (i) decisões do acionista controlador, (ii) deliberação da assembleia geral de acionistas ou dos órgãos de administração da companhia, e outros fatos ocorrido no âmbito dos negócios da companhia ${ }^{43}$. De todo modo, a informação não necessariamente é produzida pela companhia, mas também pode ser àquela que tenha efeito sobre a companhia ainda que não seja produzida por ela ${ }^{44}$.

A compreensão do termo informação relevante também pode ser extraída do artigo 157 , parágrafo $4^{\circ}$, da Lei $n^{\circ} 6.404^{45}$, como informação capaz de influenciar na decisão dos investidores de negociar com valores mobiliários de emissão da companhia ${ }^{46}$.

\footnotetext{
${ }^{42}$ Extrato da Sessão de Julgamento do Processo Administrativo Sancionador CVM n ${ }^{\circ}$ RJ2006/5928. Diretor-Relator e Presidente da sessão de julgamento: Pedro Oliva Marcilio de Sousa. Data de Julgamento: 17.04.2007. Disponível em: <http://www.cvm.gov.br/export/sites/cvm/sancionadores/sancionador/anexos/2007/20070417_PA S_RJ20065928.pdf>. Acesso em: 13.09.2017.

${ }^{43}$ EIZIRIK, Nelson. A lei das S/A Comentada. p. 142-143.

${ }^{44}$ CAMPOS, Luiz Antonio de Sampaio. Deveres e Responsabilidades. IN: LAMY FILHO, Alfredo; PEDREIRA, José Bulhões. Direito das companhias. $2^{\text {a }}$ edição. Rio de Janeiro: Forense, 2017. p. 836.

45 Artigo 157. (...) $\S 4^{\mathrm{o}}$ : “Os administradores da companhia aberta são obrigados a comunicar imediatamente à bolsa de valores e a divulgar pela imprensa qualquer deliberação da assembléiageral ou dos órgãos de administração da companhia, ou fato relevante ocorrido nos seus negócios, que possa influir, de modo ponderável, na decisão dos investidores do mercado de vender ou comprar valores mobiliários emitidos pela companhia".

${ }^{46}$ MÜSSNICH, Francisco Antunes Maciel. O insider trading no direito brasileiro. p. 36.
} 
Ainda assim, cabe esclarecer que o fato relevante previsto do artigo 157 da Lei $n^{\circ} 6.404$ não se confunde com informação privilegiada, embora ambas possuam o potencial de influir de modo ponderável na cotação das ações. É verdade que as informações divulgadas através de fato relevante, provavelmente, constituem informações privilegiadas. Mas, também é verdade que, muitas vezes, a informação privilegiada fica configurada antes da constituição do fato relevante ${ }^{47}$.

Vale ressaltar, nesse ponto, que a informação precisa ter o potencial de influir na cotação dos valores mobiliários da companhia. Nesse sentido, a ausência de oscilação da cotação de valores mobiliários após a divulgação da informação relevante não desconfigura a prática de insider trading, como, inclusive, já foi afirmado pelo Colegiado da Comissão de Valores Mobiliários no âmbito do PAS CVM nº RJ2012/13047, conforme voto do Diretor Relator Roberto Tadeu Fernandes:

(...) mas a CVM já consolidou em diversos precedentes que a oscilação, positiva ou negativa, é dispensável para caracterizar a negociação com o uso de informação relevante ainda não divulgada ao mercado, pois é suficiente que a informação indevidamente utilizada seja capaz, possua o potencial, de influir na cotação das ações $(. . .)^{48}$.

Por fim, é necessário que a informação seja sigilosa, ou seja, não tenha sido divulgada ao público em geral pelos meios legais e regulamentares de divulgação de informação de companhia aberta. A falta de publicidade da informação é o que garante a vantagem ilegítima daquele que obteve acesso à informação privilegiada em relação a todos os outros investidores do mercado de valores mobiliários.

\footnotetext{
${ }^{47}$ CAMPOS, Luiz Antonio de Sampaio. Deveres e Responsabilidades. IN: LAMY FILHO, Alfredo; PEDREIRA, José Bulhões. Direito das companhias. p. 837.

48 Extrato da Sessão de Julgamento do Processo Administrativo Sancionador CVM $\mathrm{n}^{\circ}$ RJ2012/13047. Diretor-Relator: Roberto Tadeu Antunes Fernandes. Presidente da sessão de julgamento: Leonardo P. Gomes Pereira. Data de Julgamento: 04.11.2014. Disponível em: <http://www.cvm.gov.br/export/sites/cvm/sancionadores/sancionador/anexos/2014/20141104_PA S_RJ201213047.pdf>. Acesso em: 13.09.2017.
} 
Bom, normalmente a divulgação da informação privilegiada é realizada pelo Diretor de Relações com Investidores, pelos meios previstos pela regulamentação editada pela Comissão de Valores mobiliários. Ainda assim, se a informação privilegiada for disseminada no domínio público por outro meio que não a declaração formal da companhia, a assimetria informal que justifica a proibição de negociação também poderá ser extinta ${ }^{49}$.

No âmbito do PAS CVM nº 06/2003, é possível extrair do voto da Diretora Norma Parente, o conceito de informação privilegiada como aquela que preenche os seguintes requisitos relevância e sigilo, bem como, que a partir do momento em que a informação perde seu caráter confidencial, não é mais possível a configuração do insider trading (com grifos):

Informação privilegiada, por seu turno, é aquela simultaneamente relevante e sigilosa. Para a aferição da relevância da informação, a lei estabelece parâmetros (art. 157, § $4^{\circ}$ da LSA), posteriormente complementados pela regulamentação da CVM (art. $2^{\circ}$ da Instrução CVM n ${ }^{\circ} 358 / 02$ ). A jurisprudência norte-americana, como assinala Nelson Eizirik, produziu um entendimento que bem sintetiza o espírito dos dispositivos aludidos: fato ou ato relevante é qualquer fato ou ato que seria levado em consideração por um investidor médio ao negociar com ações. Quanto ao sigilo, são menores as dificuldades em caracterizá-lo. Haverá sigilo quando a informação não puder ser obtida por meios acessíveis ao público em geral. Via de regra, a informação deixará de ser sigilosa através da publicação imediata que deve ser promovida pelos administradores. Contudo, se por qualquer outra razão ela vier a perder seu caráter confidencial, já não se prestará ao insider trading. A informação disseminada, ainda que de forma irregular e por mais relevante que seja, já será uma informação de mercado, que, portanto, presume-se refletida nas expectativas dos agentes que negociam valores mobiliários $^{50}$.

Enfim, após a divulgação da informação relevante e passado o tempo necessário para sua precificação pelo mercado de valores mobiliários, os administradores da companhia e outras pessoas que tiveram acesso a informação previamente estão aptos a negociar com os valores mobiliários

\footnotetext{
${ }^{49}$ PARENTE, Norma Jonssen. Tratado de Direito Empresarial - Volume VI-Mercado de Capitais. p. 8.

${ }^{50}$ Extrato da Sessão de Julgamento do Processo Administrativo Sancionador CVM n 06/2003. Diretor-Relator: Norma Jonssen Parente. Presidente da sessão de julgamento: Marcelo Fernandez Trindade. Data de Julgamento: 14.09.2005. Disponível em: <http://www.cvm.gov.br/export/sites/cvm/sancionadores/sancionador/anexos/2005/20050914_PA S_CVM0603.pdf>. Acesso em: 10.09.2017.
} 
da companhia - uma vez que, a situação de vantagem ilegítima não está mais configurada.

\subsubsection{Acesso a informação}

Além da existência da informação com as características acima destacadas, é necessário que uma pessoa, com capacidade de utilizar essa informação na negociação de valores mobiliários tenha acesso a tal informação ${ }^{51}$.

Questões relevantes que permeiam esse tema já foram apresentadas no item sobre insiders traders. Mas, apenas organizando, a configuração da prática de insider trading tem como elemento essencial para a sua configuração a comprovação do acesso pela pessoa que negociou com valores mobiliários de determinada companhia à informação relevante não divulgada ao mercado.

O acesso à informação relevante não divulgada ao mercado pode ocorrer direta ou indiretamente, dependendo da relação que a pessoa possui com a companhia. Quando o acesso à informação ocorre diretamente, como ocorre com os administradores da companhia, estamos diante de um insider primário. Por outro lado, quando o acesso à informação se dá de forma indireta, estamos diante de um insider de mercado.

Nesse ponto, vale notar, ainda, que para a condenação pela negociação de valores mobiliários com o uso indevido de informação privilegiada, é fato que a Comissão de Valores Mobiliários deveria comprovar o efetivo acesso a tal informação, pois a ausência de prova da obtenção da informação privilegiada implica na ausência de nexo de

\footnotetext{
${ }^{51}$ MÜSSNICH, Francisco Antunes Maciel. $O$ insider trading no direito brasileiro. p. 41.
} 
causalidade entre a conduta do investigado e o suposto resultado ilícito - o que claramente impede a condenação do mesmo

Ainda assim, para facilitar a configuração da prática de insider trading, a autarquia criou as seguintes presunções em relação aos insiders primários (i) presunção de que em certos períodos há informação privilegiada, sendo vedada a negociação com valores mobiliários da companhia e (ii) presunção de conhecimento da informação relevante ainda não divulgada ao mercado (já citadas no presente).

Conforme disposto no artigo 13 da Instrução CVM nº 358, em alguns períodos, como (i) na pendência de divulgação de fato relevante, (ii) quando há intenção de promover reorganização societária e (iii) antes da divulgação demonstrações financeiras anuais e trimestrais, é vedada a negociação com valores mobiliários emitidos pela companhia (com grifos):

Art. 13. Antes da divulgação ao mercado de ato ou fato relevante ocorrido nos negócios da companhia, é vedada a negociação com valores mobiliários de sua emissão, ou a eles referenciados, pela própria companhia aberta, pelos acionistas controladores, diretos ou indiretos, diretores, membros do conselho de administração, do conselho fiscal e de quaisquer órgãos com funções técnicas ou consultivas, criados por disposição estatutária, ou por quem quer que, em virtude de seu cargo, função ou posição na companhia aberta, sua controladora, suas controladas ou coligadas, tenha conhecimento da informação relativa ao ato ou fato relevante. (...)

$\S 3^{\circ}$ A vedação do caput também prevalecerá: I - se existir a intenção de promover incorporação, cisão total ou parcial, fusão, transformação ou reorganização societária; e II - em relação aos acionistas controladores, diretos ou indiretos, diretores e membros do conselho de administração, sempre que estiver em curso a aquisição ou a alienação de ações de emissão da companhia pela própria companhia, suas controladas, coligadas ou outra sociedade sob controle comum, ou se houver sido outorgada opção ou mandato para o mesmo fim.

$\S 4^{\circ}$ Também é vedada a negociação pelas pessoas mencionadas no caput no período de 15 (quinze) dias que anteceder a divulgação das informações trimestrais (ITR) e anuais (DFP) da companhia, ressalvado o disposto no $\S 2^{\circ}$ do art. 15-A.

Essa vedação abrange a própria companhia, seus acionistas controladores, seus membros da administração e de órgãos estatutários com funções consultivas ou técnicas e qualquer outra pessoa que tenha, em função de sua posição na própria companhia, suas controladas ou coligadas, conhecimento da informação não divulgada ao mercado. 
Além disso, foi criada a presunção de que os insiders primários possuem acesso à informação relevante ainda não divulgada ao mercado. Assim, a Comissão de Valores Mobiliários, ao formular a acusação contra essas pessoas não precisa comprovar efetivo acesso à informação privilegiada.

Já em relação aos insider secundário, de acordo com o entendimento consolidado da Comissão de Valores Mobiliários, é imprescindível que a acusação comprove o efetivo acesso à informação, uma vez que, nesses casos, não há presunção desse elemento para a configuração do ato ilícito (com grifos):

Diferentemente da regulamentação prevista para os denominados insiders primários ou típicos, que são aquelas pessoas que exercem funções junto à companhia, não se presume o conhecimento, pelos insiders secundários, da informação relevante ainda não divulgada ao mercado $^{52}$.

Mas para facilitar a comprovação do elemento ora comentado, o Colegiado da Comissão de Valores Mobiliários criou o entendimento de que não é necessário identificar o caminho exato que a informação percorreu até chegar ao insider de mercado ou comprovar quem seria a fonte primária. Nesse sentido, esclarece o trecho do voto do Diretor Marcos Barbosa Pinto no âmbito do PAS CVM no 24/2005: "o direito brasileiro permite que uma pessoa seja condenada por negociação com informação privilegiada mesmo que não se consiga precisar como essa informação foi obtida" ${ }^{33}$.

\footnotetext{
${ }^{52}$ Extrato da Sessão de Julgamento do Processo Administrativo Sancionador CVM n ${ }^{\circ}$ RJ2014/3225. Diretor-Relator: Roberto Tadeu Antunes Fernandes. Presidente da sessão de julgamento: Leonardo P. Gomes Pereira. Data de Julgamento: 13.09.2016. Disponível em: <http://www.cvm.gov.br/export/sites/cvm/sancionadores/sancionador/anexos/2016/20160913 PA S RJ20143225.pdf>. Acesso em: 10.09.2017.

${ }^{53}$ Extrato da Sessão de Julgamento do Processo Administrativo Sancionador CVM no 24/05. Diretor-Relator: Sergio Weguelin. Presidente da sessão de julgamento: Maria Helena dos Santos Fernandes de Santana. Data de Julgamento: 07.10.2008. Disponível em: <http://www.cvm.gov.br/export/sites/cvm/sancionadores/sancionador/anexos/2008/20081007_PA S_2405.pdf>. Acesso em: 10.09.2017.
} 
Abrindo um paralelo para a jurisprudência norte-americana, no caso United States v. Newman and Chaiasson julgado em dezembro de 2014, que solidificou entendimento de $1983^{54}$, abriu-se um perigoso precedente de que não só é necessário identificar a fonte da informação, mas também comprovar que o tippee sabia que a fonte era insider primário e que este recebeu ou receberia uma contrapartida em razão da transmissão da informação privilegiada ${ }^{55}$.

Enfim, todos esses artifícios têm como objetivo assegurar a responsabilização pela negociação de valores mobiliários com a utilização de informação privilegiada, em razão da evidente dificuldade probatória do acesso a informação.

\subsubsection{Utilização da Informação Privilegiada}

O terceiro elemento da configuração da prática de insider trading é a efetiva utilização da informação privilegiada na negociação de valores mobiliários. Ou seja, não basta que a pessoa tenha acesso à informação relevante não divulgada ao mercado, mas que, de fato, se aproveite da vantagem decorrente desse acesso para negociar com valores mobiliários da companhia.

Nesse sentido, é necessário que o insider tenha realizado a negociação em razão da posse de informação privilegiada. Em outras palavras, caso não tivesse acesso a referida informação privilegiada, o insider

\footnotetext{
${ }^{54}$ Caso Dirks v. SEC, 463 U.S. 646 (1983). O caso envolve um analista de valores mobiliários que recebeu informação de ex-administrador de uma companhia a respeito de um grande esquema fraudulento em tal companhia. Tal informação foi transmitida pelo analista a clientes seus que puderam usar tal informação em negociações com ações emitidas pela companhia. Na decisão, estabelece-se que aquele que recebe a informação só poderá ser responsabilizado, se seu informante recebeu alguma contrapartida pela transmissão da informação.

${ }^{55}$ BARBOSA, Marcelo. Algumas notas sobre insider trading. IN: VENANCIO FILHO, Alberto; LOBO, Carlos Augusto Silveira; ROSMAN, Luiza Alberto Colonna. LEI das S.A. em seus 40 anos. p. 295.
} 
não haveria negociado com valores mobiliários emitidos por uma companhia específica.

Ainda assim, a utilização da informação é um elemento que sempre dependerá da análise caso a caso no âmbito de Processo Sancionador instaurado pela Comissão de Valores Mobiliários.

\subsubsection{Intenção de obter vantagem indevida}

Por fim, o quarto elemento necessário para a configuração da prática de insider trading: a intenção de obter vantagem na negociação com o uso indevido de informação privilegiada. Quando falamos de intenção, obviamente, chegamos ao elemento subjetivo da conduta - mesmo que todos os outros elementos estejam presentes, a conduta não poderá ser penalizada caso o insider não negocie com esse animus de obter vantagem.

Ainda assim, o Colegiado da Comissão de Valores Mobiliários entende que a efetiva obtenção de vantagem em razão da negociação de valores mobiliários com a utilização de informação privilegiada não é elemento essencial para a configuração do ilícito insider trading. Nessa linha, transcrevo voto do Diretor Marcelo Fernandez Trindade no âmbito do PAS $\mathrm{CVM} \mathrm{n}^{\circ}$ 04/04:

Veja-se que a finalidade de obter vantagem constitui elemento subjetivo do tipo, que o faz doloso, e que se traduz na intenção do agente de produzir um resultado. A produção do resultado, em si mesma - isto é, no caso concreto, a efetiva obtenção da vantagem visada - é elemento objetivo, não se confunde com a finalidade (que é a intenção do agente), e não integra a conduta descrita nos arts. $155, \S \S 1^{\circ}$ e $4^{\circ}$, da Lei das S.A., e no art. 13 da Instrução $358 / 02^{56}$.

56 Extrato da Sessão de Julgamento do Processo Administrativo Sancionador CVM no 04/04. Diretor-Relator e Presidente da sessão de julgamento: Marcelo Fernandez Trindade. Data de Julgamento: 28.06.2006. Disponível em: <http://www.cvm.gov.br/export/sites/cvm/sancionadores/sancionador/anexos/2006/20060628_PA S 0404.pdf>. Acesso em: 10.09.2017. 
Lembrando, no entanto, que para que o acusado seja civilmente responsabilizado, é necessária a existência de dano - que só ficará configurado caso o insider, de fato, obtenha vantagem com a negociação.

Outro ponto interessante levantado pelo professor Francisco Müssnich é que o presente elemento, apesar de textualmente expresso no artigo 155 , parágrafo $4^{\circ}$, Lei $\mathrm{n}^{\circ} 6.404$, não é endereçado no artigo 13 da Instrução CVM n 358 . Na realidade, não há qualquer menção à intenção do agente na prática de insider trading no âmbito da Instrução CVM n $358^{57}$.

A verdade é que a ausência de elemento subjetivo previsto no dispositivo ora mencionado apenas confirma a presunção já apresentada no item anterior, de que insiders primários têm a intenção de obter vantagem quando negociam na posse de informação privilegiada. Como já explicado, não se trata de uma presunção absoluta, pois, do contrário, essa questão apresentaria uma perigosa espécie de responsabilidade objetiva no âmbito administrativo sancionador - o que seria inadmissível.

Até porque, a Instrução $\mathrm{CVM} \mathrm{n}^{\circ} 358$, como norma regulamentar, não tem competência para afastar requisito previsto em dispositivo legal ${ }^{58}$. Enfim, para que o investigado possa ser responsabilizado existe a necessidade do elemento subjetivo ainda que este possa ser presumido, como se extrai do o voto do Diretor Pablo Renteria no âmbito do PAS CVM no RJ2011/3823 (com grifos):

24. Note-se, a propósito, que o art. 13 da Instrução CVM no 358/2002 não estabelece, a rigor, hipóteses de inversão do ônus da prova, o que, a meu ver, sequer seria aceitável em sede de processo administrativo sancionador. Antes disso, reconhece a admissão, nas situações ali descritas, da prova indireta mediante presunção simples, também denominada presunção judicial ou prova indiciária, a qual não se confunde com a presunção legal.

(....)

26. Com efeito, nos casos contemplados no art. 13 da Instrução CVM $n^{\circ}$ 358/2002, a CVM considera determinado fato provado (e.g., o fato de o

\footnotetext{
${ }^{57}$ MÜSSNICH, Francisco Antunes Maciel. $O$ insider trading no direito brasileiro. p. 50.

${ }^{58}$ MÜSSNICH, Francisco Antunes Maciel. O insider trading no direito brasileiro. p. 54.
} 
investigado ser administrador da companhia aberta) como indício hábil a autorizar, por indução, a conclusão quanto à ocorrência de fatos que configuram a prática do insider trading (o conhecimento da informação relativa ao fato relevante pendente de divulgação e o intuito de obter de vantagem $)^{59}$.

Bom, apenas com a presença - e, evidentemente, a comprovação de todos os elementos descritos acima justifica-se a responsabilização de acusado pela prática de negociação de valores mobiliários com a utilização de informação relevante não divulgada ao mercado.

\subsection{Responsabilização Civil, Administrativa e Penal}

Agora, finalizaremos $\mathrm{o}$ presente Capítulo apresentando a responsabilização daquele que pratica a negociação de valores mobiliários com o uso indevido de informações privilegiadas. A prática do ilícito insider trading pode acarretar sanções nas esferas cível, administrativa e criminal ${ }^{60}$.

Primeira, em relação a responsabilidade civil, o investidor que negocia valores mobiliários, sem ter conhecimento da informação relevante, tem o direito de indenização pelas perdas e danos sofridos a ser paga pelos insiders, nos termos do artigo 155, parágrafo $2^{\circ}$ da Lei $n^{\circ} 6.404$ (comentado acima).

Nesse caso, as perdas e danos devem ser calculados pela "diferença entre a cotação de valores mobiliários ao tempo da operação e aquela verificada imediatamente após a divulgação do fato relevante" ${ }^{31}$.

É fato que, como em transações realizadas no mercado de valores mobiliários, em regra, não existe uma relação própria entre a ponta

\footnotetext{
${ }^{59}$ Extrato da Sessão de Julgamento do Processo Administrativo Sancionador CVM n ${ }^{\text {RJ } 2011 / 3823 . ~}$ Diretor-Relator: Pablo Renteria. Presidente da sessão de julgamento: Leonardo P. Gomes Pereira. Data de Julgamento: 09.12.2015. Disponível em: <http://www.cvm.gov.br/export/sites/cvm/sancionadores/sancionador/anexos/2015/20151209 PA S_RJ20113823.pdf >. Acesso em: 10.09.2017.

${ }^{60}$ EIZIRIK, Nelson. A lei das S/A Comentada. p. 144.

${ }^{61}$ EIZIRIK, Nelson. A lei das S/A Comentada. p. 144.
} 
compradora e a ponta vendedora, não é necessário a comprovação de que a outra ponta da transação estava na posse de informação privilegiada.

Assim, só é necessário comprovar que pessoas com a utilização de informações privilegiadas estavam negociando com determinado valor mobiliário - para que estas fiquem obrigadas a ressarcir as perdas e danos daqueles que estavam negociando com o mesmo valor mobiliário e não tinham conhecimento da referida informação.

Além disso, na esfera cível, também cabe ressaltar a possibilidade do Ministério Público ajuizar ação civil pública para ressarcimento de danos sofridos pelos investidores no âmbito do mercado de capitais, conforme previsto no artigo $1^{\circ}$ da Lei $\mathrm{n}^{\circ} 7.913$ de 7 de dezembro de 1989 ("Lei ${ }^{\circ}$

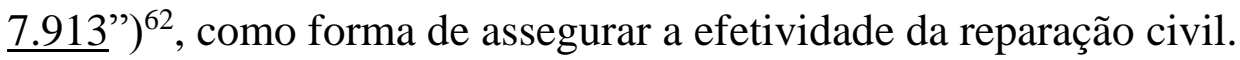

A responsabilidade administrativa pela prática da negociação de valores mobiliários com o uso indevido de informações privilegiadas, por sua vez, está prevista no artigo 155 , parágrafos $1^{\circ}$ e $4^{\circ}$, da Lei n ${ }^{\circ} 6.404$, bem como no artigo 13 da Instrução CVM no 358 - todos já descritos acima.

A análise da responsabilidade administrativa é de competência da Comissão de Valores Mobiliários, que deve "apurar objetivamente, mediante

\footnotetext{
62 Artigo $1^{\text {o: }}$ "Sem prejuízo da ação de indenização do prejudicado, o Ministério Público, de ofício ou por solicitação da Comissão de Valores Mobiliários - CVM, adotará as medidas judiciais necessárias para evitar prejuízos ou obter ressarcimento de danos causados aos titulares de valores mobiliários e aos investidores do mercado, especialmente quando decorrerem de: I - operação fraudulenta, prática não eqüitativa, manipulação de preços ou criação de condições artificiais de procura, oferta ou preço de valores mobiliários; II - compra ou venda de valores mobiliários, por parte dos administradores e acionistas controladores de companhia aberta, utilizando-se de informação relevante, ainda não divulgada para conhecimento do mercado ou a mesma operação realizada por quem a detenha em razão de sua profissão ou função, ou por quem quer que a tenha obtido por intermédio dessas pessoas; III — omissão de informação relevante por parte de quem estava obrigado a divulgá-la, bem como sua prestação de forma incompleta, falsa ou tendenciosa".
} 
inquérito administrativo, os atos ilegais levados a efeito pelos insiders"63, nos termos do artigo $9^{\circ}$, inciso $\mathrm{V}$, da Lei $\mathrm{n}^{\circ} 6.385^{64}$.

É bem verdade que a Comissão de Valores Mobiliário foi criada em razão da necessidade de tutela estatal no mercado de valores mobiliários do país como consta, inclusive, da Exposição de Motivos no 197 da Lei no 6.385 - lei responsável pela criação da Comissão de Valores Mobiliários com o objetivo de fiscalizar, normatizar, disciplinar e desenvolver o mercado capitais no Brasil:

A experiência demonstrou que a defesa da economia popular e o funcionamento regular do mercado de capitais exigem a tutela do Estado, com a fixação de normas para emissão de títulos destinados ao público, divulgação de dados sobre a companhia emitente e negociação dos títulos no mercado. Além disso, é necessário que agência governamental especializada exerça as funções de polícia do mercado, evitando as distorções e abusos a que está sujeito ${ }^{65}$.

Assim, a Comissão de Valores Mobiliários instaura Processo Sancionador para analisar se houve a prática de negociação com o uso indevido de informação privilegiada e, com a condenação, tem o poder de aplicar às penalidades previstas no artigo 11 da Lei $n^{\circ} 6.385$.

Nesse ponto, cabe lembrar que a prática do ilícito insider trading constitui infração grave nos termos da Instrução CVM n ${ }^{\circ}$ 491, de 22 de fevereiro de 2011 (“Instrução CVM n 491") - podendo ser aplicada qualquer modalidade de pena constante do artigo 11 da Lei $n^{\circ} 6.385^{66}$. Ainda assim,

\footnotetext{
${ }^{63}$ CARVAlHOSA, Modesto. Comentários à lei de sociedades anônimas. p. 443.

${ }^{64}$ Artigo 9: "A Comissão de Valores Mobiliários, observado o disposto no $\S 2$ o do art. 15, poderá: (...) $V$ - apurar, mediante processo administrativo, atos ilegais e práticas não eqüitativas de administradores, membros do conselho fiscal e acionistas de companhias abertas, dos intermediários e dos demais participantes do mercado".

6565 SIMONSEN, Mário Henrique. Exposição de Motivos do Senhor Ministro da Fazenda $n^{o}$ 197, o anexo projeto de lei que "dispõe sobre o mercado de valores mobiliários e cria a Comissão de Valores Mobiliários - CVM". Disponível <http://www.cvm.gov.br/export/sites/cvm/legislacao/leis-decretos/anexos/EM197-Lei6385.pdf $>$. Acesso em: 09.09.2017.

${ }^{66}$ Artigo 11: “A Comissão de Valores Mobiliários poderá impor aos infratores das normas desta Lei, da lei de sociedades por ações, das suas resoluções, bem como de outras normas legais cujo cumprimento the incumba fiscalizar, as seguintes penalidades: I - advertência; II - multa; III suspensão do exercício do cargo de administrador ou de conselheiro fiscal de companhia aberta, de entidade do sistema de distribuição ou de outras entidades que dependam de autorização ou
} 
na maioria, esmagadora, das vezes, a penalidade aplicada é a multa - cujos critérios de aplicação estão previstos no parágrafo $1^{\circ}$ do artigo 11 da Lei ${ }^{\circ}$ 6.385 .

Nesse ponto, cabe mencionar que a nova Lei $\mathrm{n}^{\circ} 13.506$ foi responsável por alterar os critérios para a fixação da multa no âmbito de julgamento de Processo Sancionador pelo Colegiado da Comissão de Valores Mobiliários. Assim, pela nova redação do parágrafo $1^{\circ}$, do artigo 11 , da Lei $\mathrm{n}^{\mathrm{o}} 6.385$, os seguintes critérios podem ser utilizados para a fixação da penalidade de multa: (i) até $\mathrm{R} \$ 50.000 .000,00$ (cinquenta milhões de reais); (ii) dobro do valor da emissão ou da operação irregular; (iii) três vezes o montante da vantagem econômica obtida ou da perda evitada; e (iv) o dobro do prejuízo causado aos investidores.

Cabe mencionar ainda que a Comissão de Valores Mobiliários entende que prática de insider trading deve ser punida de forma bastante rigorosa, em razão de suas consequências, como a capacidade de subverter a confiança dos participantes no mercado de capitais e nas informações divulgadas por companhias abertas ${ }^{67}$.

Por fim, como já mencionado na esfera criminal o tipo penal "Uso Indevido de Informação Privilegiada" era próprio, ou seja, só podiam ser responsabilizados penalmente pela utilização de informação privilegiada na negociação de valores mobiliários, aqueles que possuem o dever de guardar sigilo de tal informação. De todo modo, com o advento da Lei $n^{\circ} 13.506$, a

registro na Comissão de Valores Mobiliários; IV - inabilitação temporária, até o máximo de vinte anos, para o exercício dos cargos referidos no inciso anterior; $V$ - suspensão da autorização ou registro para o exercício das atividades de que trata esta Lei; VI - cassação de autorização ou registro, para o exercício das atividades de que trata esta Lei; VII - proibição temporária, até o máximo de vinte anos, de praticar determinadas atividades ou operações, para os integrantes do sistema de distribuição ou de outras entidades que dependam de autorização ou registro na Comissão de Valores Mobiliários; VIII - proibição temporária, até o máximo de dez anos, de atuar, direta ou indiretamente, em uma ou mais modalidades de operação no mercado de valores mobiliários".

${ }^{67}$ EIZIRIK, Nelson. A lei das S/A Comentada.p. 146. 
descrição do tipo penal, prevista no artigo 27-D da Lei ${ }^{\circ} 6.385$ foi alterada de forma a abranger a conduta realizada pelo insider secundário.

O "Uso Indevido de Informação Privilegiada" deixou de ser um crime próprio. Assim, a partir da Lei n 13.506 , é possível a responsabilização pela negociação de valores mobiliário com o uso indevido de informação privilegiada quando cometido por qualquer pessoa, independentemente de sua relação com a companhia emissora de valores mobiliários.

Além disso, como já mencionado, a Lei no 13.506 foi responsável por tipificar a conduta do agente que repassa informações privilegiadas, das quais teve conhecimento "em razão de cargo ou posição que ocupe em emissor de valores mobiliários ou em razão de relação comercial, profissional ou de confiança com o emissor" ${ }^{\prime}$. Como é possível extrair da redação do dispositivo, nesse caso, apenas aqueles com acesso a informação diretamente pela companhia podem ser responsabilizados.

A pena culminada em abstrato para a condenação pela prática do "Uso Indevido de Informação Privilegiada" (também aplicável ao repasse de informações previsto no parágrafo $1^{\circ}$ do artigo 27-D da Lei ${ }^{\circ}$ 6.385), não foi modificada pela nova Lei $\mathrm{n}^{\mathrm{o}} 13.506$, permanecendo com a seguinte redação: “reclusão, de 1 (um) a 5 (cinco) anos, e multa de até 3 (três) vezes o montante da vantagem ilícita obtida em decorrência do crime"69.

Por outro lado, o parágrafo $2^{\circ}$ do artigo $27-\mathrm{D}$, incluído pela Lei $\mathrm{n}^{\mathrm{o}}$ 13.506, estabelece que a negociação pelo agente com informação privilegiada da qual tenha conhecimento e deva manter sigilo (ou seja,

68 BRASIL. Lei $n^{o}$ 6.385, de 07 de dezembro de 1976. Disponível em: <https://www.planalto.gov.br/ccivil_03/leis/L6385.htm>. Acesso em: 09.12.2017.

69 BRASIL. Lei $n^{o}$ 6.385, de 07 de dezembro de 1976. Disponível em: <https://www.planalto.gov.br/ccivil_03/leis/L6385.htm>. Acesso em: 09.12.2017. 
somente aplicável para insiders primários) é causa de aumento da pena em 1/3 (um terço).

Essa norma está em linha com o entendimento da Comissão de Valores Mobiliários de que a reprovabilidade da conduta de insider trading, quando cometida por aquele que tem deveres fiduciários para com a companhia (como o dever de guardar sigilo), é maior e, portanto, nesses casos, as penas devem ser mais elevadas.

Vale lembrar, ainda, que a prática de insider trading é analisada no âmbito de ação penal pública incondicionada - nesse sentido, a Comissão de Valores Mobiliários, após constatar a prática do ilícito insider trading, oficia o Ministério Público (legitimado ativo).

Bom, é evidente, por todo o exposto neste Capítulo, o quão infecciosa a prática de insider trading é para o mercado de valores mobiliários e, dessa forma, sendo justificável a severidade das penas aplicáveis e a responsabilização em tantos âmbitos do Direito. 


\section{CONSIDERAÇÕES SOBRE A PROVA INDICIÁRIA}

\subsection{Introdução}

O Estado, seja através do Poder Judiciário ou de outras instituições da Administração Pública, é o titular do poder punitivo quando um indivíduo pratica uma conduta tipificada penal e/ou administrativamente, para impor a devida penalidade de forma legítima.

Ainda assim, em um Estado Democrático de Direito, como o qual vivemos atualmente, o poder punitivo do Estado só poderá ser exercido de forma limitada, assegurando o respeito às garantias individuais do cidadão constantes da Constituição da República Federativa do Brasil de 1988 (“Constituição Federal de 1988”) 70 .

É bem por isso que o processo penal, bem como o Processo Sancionador, é marcado pelo conflito entre o direito de punir do Estado e as garantias individuais do cidadão.

Nesse sentido, os sujeitos de direito contemplados pelo ordenamento brasileiro — não apenas pessoas naturais, mas também pessoas jurídicas só poderão ser punidos quando respeitado o devido processo legal, contemplado pelo artigo $5^{\circ}$, inciso LIV, da Constituição Federal de $1988^{71}$.

Para tanto, é necessário que no âmbito de procedimento legalmente regulamentado seja comprovado a prática da conduta ilícita, com todos seus elementos, bem como a autoria e culpabilidade do agente.

\footnotetext{
70 BRASIL. Constituição da República Federativa do Brasil de 1988. Disponível em: <http://www.planalto.gov.br/ccivil_03/constituicao/constituicaocompilado.htm>. Acesso em: 08.10.2017.

${ }^{71}$ Artigo 50. (...) LIV: “ninguém será privado da liberdade ou de seus bens sem o devido processo legal";
} 
Também, nos termos do princípio da presunção da inocência, previsto no artigo $5^{\circ}$, inciso LVII, da Constituição Federal de $1988^{72}$, é necessário que a comprovação da autoria e materialidade da conduta ilícita supere a dúvida razoável, para que a condenação e imposição de penalidade sejam legítimas.

Além disso, ainda em linha com o princípio da presunção de inocência e diferentemente da lógica que rege o processo civil e as demais áreas do direito, em princípio, o ônus da prova recai sobre a acusação, que deve apresentar provas que atestem todos os elementos necessários para configuração da conduta de modo que a condenação esteja justificada.

Dessa forma, a prova, como instrumento utilizado pelos sujeitos processuais para comprovar os fatos alegados no âmbito do processo, tem a precípua finalidade, tanto para a acusação como para a defesa, de formar o convencimento do julgador.

Além disso, pelo princípio do livre convencimento motivado, positivado em nosso ordenamento jurídico pelo artigo 155 do Decreto-Lei ${ }^{\circ}$ 3.689, de 3 de outubro de 1941 ("Código de Processo Penal”) 73, bem como pelo artigo 93, inciso IX, da Constituição Federal de $1988^{74}$, não existe uma hierarquia pré-determinada do valor de cada prova, cabendo ao juiz valorar as provas apresentadas no âmbito do processo para motivar sua decisão. De acordo com esse princípio, que rege o sistema de persuasão racional positivado no ordenamento atual, cabe ao julgador formar o seu

\footnotetext{
${ }^{72}$ Artigo $5^{\circ}$. (...) LVII: “ninguém será considerado culpado até o trânsito em julgado de sentença penal condenatória".

${ }_{73}$ Artigo 155: "O juiz formará sua conviç̧ão pela livre apreciação da prova produzida em contraditório judicial, não podendo fundamentar sua decisão exclusivamente nos elementos informativos colhidos na investigação, ressalvadas as provas cautelares, não repetíveis e antecipadas".

${ }^{74}$ Artigo 93. (...) IX: "todos os julgamentos dos órgãos do Poder Judiciário serão públicos, $e$ fundamentadas todas as decisões, sob pena de nulidade, podendo a lei limitar a presença, em determinados atos, às próprias partes e a seus advogados, ou somente a estes, em casos nos quais a preservação do direito à intimidade do interessado no sigilo não prejudique o interesse público à informação".
} 
convencimento de maneira livre e racional, com base no conjunto de provas constante dos autos.

Feita essa introduz sobre o funcionamento do processo penal e, consequentemente, do Processo Sancionador, no presente Capítulo vamos atentar para a análise da prova indiciária como motivação para a decisão de julgamento, apresentando o conceito dessa espécie de prova, bem como considerações a ela relacionadas presentes em julgamentos, principalmente, no âmbito da Comissão de Valores Mobiliários.

\subsection{Conceito e Valor Probante da Prova Indiciária}

Há quem diga que a palavra indício seja derivada do latim indiciu, que pode ser entendido como indicar, apontar, revelar, dentre outros significados. O conceito jurídico da referida palavra não se afasta tanto de sua etimologia, ao passo que, como será visto a seguir, o indício revela, algum elemento do fato, sem, no entanto, comprová-lo por inteiro. Nesse sentido, de acordo com Francesco Carrara:

(...) em direito penal se denominam indícios aquelas circunstâncias que, embora não constituam em si o delito, e sejam materialmente diversas da ação criminosa, sem embargo a revelam, por uma certa relação que pode existir entre tais circunstâncias e o fato criminoso que se investiga ${ }^{75}$.

Já nas palavras de Assis de Moura, indício deve ser entendido como todo e qualquer "rastro, vestígio, sinal e, em geral, todo fato conhecido, devidamente provado", que permite "conduzir ao conhecimento de outro fato desconhecido, a ele relacionado por meio de um raciocínio indutivodedutivo"76.

Ou seja, o indício é um instrumento para a comprovação do fato probando, mas que não se confunde com o mesmo, pois se refere a fatos

75 CARRARA, Francesco. Programa do curso de direito criminal. Volume 1. Campinas: LZN, 2002. p. 344.

${ }^{76}$ ASSIS MOURA, Maria Thereza Rocha de. A Prova por indícios no Processo Penal. São Paulo: Saraiva, 1994. P. 38. 
diversos deste. Por fim, mas na mesma linha de pensamento, no entendimento da professora Norma Parente:

(...) o indício é um fato provado e conhecido, que se destina a revelar, a despontar e a tornar visível outro fato dolosamente camuflado, escondido e disfarçado, sendo que a presunção é o raciocínio que se faz a partir do fato certo e provado para comprovar fato incerto e provável ${ }^{77}$.

Enfim, indício é todo e qualquer fato ou circunstância, certo e provado, que possui conexão com o fato que se pretende $\operatorname{provar}^{78}$. Tal definição está em linha com o artigo 239 do Código de Processo Penal, que estabelece que indício é "a circunstância conhecida e provada, que, tendo relação com o fato, autorize, por indução, concluir-se a existência de outra ou outras circunstâncias"79.

As conclusões formuladas com base em indícios possuem uma relação de probabilidade com o fato probando. Mesmo que não seja possível assegurar a certeza, é necessário garantir que essas conclusões não sejam derivadas de possibilidades e meras conjecturas ${ }^{80}$.

Assim, o indício (fato certo e provado) é o ponto de partida para a construção da prova indiciária. A prova indiciária, por sua vez, é o resultado de uma construção lógica a partir do raciocínio indutivo, que estabelece a conexão entre diversos fatos conhecidos e provados (indícios) e o fato que se pretende provar.

Na prática, em muitos casos, os fatos conhecidos e provados não constituem elementos do objeto principal do processo, mas através do

\footnotetext{
${ }^{77}$ PARENTE, Norma Jonssen. Tratado de Direito Empresarial - Volume VI - Mercado de Capitais. p. 23.

${ }^{78}$ RANGEL, Paulo. Direito Processual Penal. 12 ${ }^{\mathrm{a}}$ edição. Rio de Janeiro: Editora Lumen Juris, 2007. p. 428.

79 BRASIL. Decreto-Lei $\mathrm{n}^{\circ}$ 3.689, de 3 de outubro de 1941. Disponível em: <http://www.planalto.gov.br/ccivil 03/decreto-lei/Del3689.htm>. Acesso em: 08.10.2017.

${ }^{80}$ PARENTE, Norma Jonssen. Tratado de Direito Empresarial - Volume VI - Mercado de Capitais. p. 23.
} 
raciocínio lógico é possível construir uma conexão que conduz ao conhecimento de elemento ou circunstância desconhecida do fato probando.

Nesse sentido, a prova indiciária é o clássico exemplo de prova indireta. Ou seja, de prova que não tem relação imediata com a conduta, o fato que se quer provar, mas pela qual é possível chegar ao fato, ou pelo menos, a parte dele, através de uma construção lógica.

Não há dúvidas sobre a validade da prova indiciária no processo penal e Processo Sancionador, primeiro, em razão de sua previsão expressa no artigo 239 do Código de Processo Penal, mas também é possível se extrair do artigo $5^{\circ}$, inciso LVI, da Constituição Federal de $1988^{81}$, que todos “os meios de provas tidos como lícitos pelo ordenamento jurídico, ou seja: provas documentais; testemunhas; confissão; indícios; e diligências realizadas por funcionários do órgão administrativo" $" 82$.

Além disso, na Lei n’ 13.105, de 16 de março de 2015.(“Código de Processo Civil") a validade da prova indiciária é atestada nos seguintes dispositivos (i) permissão para as partes da utilização de todos os meios legais, bem como os moralmente aceitos, para comprovação da verdade dos fatos, previsto artigo 369 do Código de Processo Civil ${ }^{83}$, (ii) princípio do livre convencimento do juiz, constante do artigo 371 Código de Processo Civil $^{84}$ e (iii) permissão para o juiz aplicar regras da experiência comum

\footnotetext{
${ }^{81}$ Artigo $5^{\circ}$. (...) LVI: "são inadmissíveis, no processo, as provas obtidas por meios ilícitos".

${ }^{82}$ EIZIRIK, Nelson; GAAL, Ariádna B.; PARENTE, Flávia; HENRIQUES, Marcus de Freitas. Mercado de capitais - regime jurídico. p. 339.

${ }^{83}$ Artigo 369: "As partes têm o direito de empregar todos os meios legais, bem como os moralmente legítimos, ainda que não especificados neste Código, para provar a verdade dos fatos em que se funda o pedido ou a defesa e influir eficazmente na convicção do juiz".

${ }^{84}$ Artigo 371: "O juiz apreciará a prova constante dos autos, independentemente do sujeito que a tiver promovido, e indicará na decisão as razões da formação de seu convencimento”.
} 
subministradas pela observação do que ordinariamente acontece, previsto no artigo 375 do Código de Processo Civil ${ }^{8586}$.

Enfim, a prova indiciária é um meio de prova positivado nos termos do já mencionado artigo 239 do Código de Processo Penal ${ }^{87}$, podendo para tanto, ser utilizado para justificar a condenação de acusado no âmbito de processo penal e, consequentemente, no âmbito de Processo Sancionador.

\subsection{Prova Indiciária e Insider Trading}

Como se sabe, é entendimento consolidado da Comissão de Valores Mobiliários que a comprovação de um ou mais elementos da prática de insider trading pode ser feita através da prova indiciária ${ }^{88}$.

Até mesmo no primeiro Processo Sancionador instaurado para a apuração da prática de utilização de informação privilegiada por administradores da Servix Engenharia S.A., julgado em 02.02.1979 pela Comissão de Valores Mobiliários, a prova indiciária foi utilizada para justificar a condenação dos acusados. Inclusive, tal decisão foi submetida ao crivo do Poder Judiciário ${ }^{89}$, que manteve a condenação e fixou a seguinte tese: "uma série de indícios veementes, perspícuos, formando um conjunto

\footnotetext{
${ }^{85}$ Artigo 375: “O juiz aplicará as regras de experiência comum subministradas pela observação do que ordinariamente acontece e, ainda, as regras de experiência técnica, ressalvado, quanto a estas, o exame pericial".

${ }^{86}$ PARENTE, Norma Jonssen. Tratado de Direito Empresarial - Volume VI-Mercado de Capitais. p. 22.

87 Artigo 239: “Considera-se indício a circunstância conhecida e provada, que, tendo relação com o fato, autorize, por indução, concluir-se a existência de outra ou outras circunstâncias".

${ }^{88}$ Cito, por exemplo: (i) Processo Administrativo Sancionador CVM nº RJ2013/10579, data de julgamento: 10.03.2015, Diretor-Relator: Roberto Tadeu Antunes Fernandes; (ii) Processo Administrativo Sancionador CVM no RJ2014/3225, data de julgamento: 13.09.2016, DiretorRelator: Roberto Tadeu Antunes Fernandes; e (iii) Processo Administrativo Sancionador CVM n ${ }^{\circ}$ 25/2010, data de julgamento: 04.07.2017, Diretor-Relator: Henrique Balduino Machado Moreira.

${ }^{89}$ Extrato da Sessão de Julgamento do Processo Administrativo Sancionador CVM no 25/2010. Diretor-Relator: Henrique Balduino Machado Moreira. Presidente da sessão de julgamento: Leonardo P. Gomes Pereira. Data de Julgamento: 04.07.2017. Disponível em: 〈http://www.cvm.gov.br/export/sites/cvm/sancionadores/sancionador/anexos/2017/25_2010.pdf >. Acesso em: 10.10.2017.
} 
probatório convincente da prática do insider trading, incide, destarte, a regra do art. 155, e seus parágrafos, da Lei 6.404/76"90.

Na realidade, antes mesmo do julgamento desse emblemático caso, foi elaborado um estudo pela Superintendência Jurídica da Comissão de Valores Mobiliários. Nesse ponto, salienta-se a importância do referido estudo como primeiro documento oficial da Comissão de Valores Mobiliários que sustenta a possibilidade de decisão da apuração de utilização de informações privilegiada com fundamento em indícios (com grifos):

No "insider trading", onde se verifica uma omissão dolosa, o convencimento do juiz, na maior parte das vezes, será feito com base em indícios, que terão como conseqüência presunções, ou talvez até mesmo através de normas da experiência comum, subministradas pela observação do que ordinariamente acontece (prova baseada na experiência - denominada prova "prima facie"). (...)

Da leitura de diversas opiniões citadas por Moacyr Amaral Santos, na obra mencionada, parece-nos acertado concluir que indícios são fatos acertos. Isoladamente despidos de valor, mas analisados em conjunto com outros fatos, conduzem a conclusões.

Já a presunção parte de um indício, um fato certo, sendo o juízo formado por um ou vários indícios, em relação a um fato certo. Em resumo, presunções são conseqüências deduzidas de um fato conhecido (indício) para chegar a um fato desconhecido.

(...)

Pelo exposto, o juiz, quando formar seu convencimento baseado em presunções, deve atentar para que sejam graves, precisas e concordantes ${ }^{91}$.

Até hoje, para a condenação de investidor pela utilização de informações privilegiadas na negociação de valores mobiliários, e outras condutas ilícitas analisadas no âmbito da Comissão de Valores Mobiliários, com fundamento em prova indiciária é necessária a apresentação pela acusação de indício múltiplos, veementes, convergentes e graves, conforme trecho constante do PAS CM no 24/05 (com grifos):

[A] existência de qualquer indício não é suficiente para ensejar a condenação. Há que se diferenciar o indício da prova indiciária, eis que, de fato, o mero indício

\footnotetext{
${ }^{90}$ PARENTE, Norma Jonssen. Tratado de Direito Empresarial - Volume VI-Mercado de Capitais. p. 14.

${ }^{91}$ PARENTE, Norma Jonssen. Aspectos Jurídicos do "insider trading". Superintendência Jurídica, junho de $1978 . \quad$ Disponível em: <http://www.cvm.gov.br/export/sites/cvm/menu/acesso_informacao/serieshistoricas/estudos/anexo s/Aspectos-Juridicos-do-insider-trading-NJP.pdf>. Acesso em: 30.10.2017.
} 
não autoriza a condenação, mas tão somente a prova indiciária, quando representada por indícios múltiplos, veementes, convergentes e graves, que autoriza uma conclusão robusta e fundada acerca do fato que se quer provado ${ }^{92}$.

É obvio que a existência de qualquer indício não justifica a condenação por conduta ilícita. Assim, em linha com o trecho transcrito acima, esclarece o Diretor Luiz Antônio Campos, ao diferenciar prova indiciária de indício, que apenas a prova indiciária constituída por indícios múltiplos, veementes, convergentes e graves pode fundamentar a condenação por conduta ilícita (destacou-se):

Todavia, o ponto fundamental para este tipo de questão, em tese, é que não basta qualquer índicio; a existência de qualquer indício não é suficiente para ensejar a condenação. Há que se diferenciar o indício da prova indiciária, eis que, de fato, o mero indício não autoriza a condenação, mas tão-somente a prova indiciária, quando representada por indícios múltiplos, veementes, convergentes e graves, que autoriza uma conclusão robusta e fundada acerca do fato que se quer provado, respeitado, naturalmente, o princípio do livre convencimento do Juiz ${ }^{33}$.

Ainda assim, ao destrinchar as características dos indícios, a Diretora

Norma Parente, afirma que é possível a condenação pela prática de insider

trading com base em apenas um indício, contanto que este seja capaz de formar a convicção do julgador (com grifos):

É nessa linha que a doutrina entende que os indícios devem ter as seguintes características: (i) graves (relativa ao convencimento que as infundem); (ii) precisos (que não se prestam a dúvidas ou a contradições lógicas); e (iii) concordes (quando, tendo origem comum ou diferente, tendem, por seu conjunto e acordo, a estabelecer o fato que se quer provar). Em relação a este último, vale dizer que, não havendo mais de um indício, visto que não é o número, mas a qualidade e o seu peso que criam a convicção, pode o juiz, baseado em apenas um só indício, concluir pelo fato que se pretende provar ${ }^{94}$.

92 Extrato da sessão de julgamento do Processo Administrativo Sancionador CVM 24/05. DiretorRelator: Sergio Weguelin. Presidente da sessão de julgamento: Maria Helena dos Santos Fernandes de Santana. Data de Julgamento: 07.10.2009. Disponível em: <http://www.cvm.gov.br/sancionadores/sancionador/2008/20081007_2405.html >. Acesso em: 10.10.2016.

93 Extrato da Sessão de Julgamento do Processo Administrativo Sancionador CVM no 22/94. Diretor-Relator: Luiz Antonio de Sampaio Campos. Presidente da sessão de julgamento: Luiz Leonardo Cantidiano. Data de Julgamento: 15.04.2004. Disponível em: <http://www.cvm.gov.br/export/sites/cvm/sancionadores/sancionador/anexos/2004/20040415_PA S 2294.pdf>. Acesso em: 10.10.2017.

${ }^{94}$ PARENTE, Norma Jonssen. Tratado de Direito Empresarial - Volume VI-Mercado de Capitais. p. 23. 
Assim, quando presentes os elementos necessário para a formação do convencimento do juiz, a condenação de prática ilícita com fundamento em prova indiciária é legitima. Mesmo assim, para tanto, primeiro, é indispensável que os indícios constantes dos autos constituam mais do que uma mera conjectura e, segundo, é necessário que não sejam apresentados contra indícios capazes de infirmar ou enfraquecer a tese acusatória.

Lembramos, ainda, que para a condenação do agente é indispensável a comprovação da conduta ilícita que supere a dúvida razoável, em razão do já mencionado princípio da presunção de inocência. Nesse sentido, explica o Diretor Pedro Oliva Marcilio de Sousa, no âmbito do PAS CVM nº 09/04, que não basta a coerência e plausibilidade da tese acusatória, mas a sua efetiva comprovação (com grifos):

A coerência e plausibilidade da teoria da acusação, no entanto, não são suficientes para sancionar a conduta de qualquer pessoa em um Estado de Direito. Faz-se necessário comprovar a teoria, não pela simples demonstração do resultado das operações ou pela demonstração de que a performance dos indiciados diminuiu substancialmente após a saída do indiciado Bernardo Clemente da sociedade para qual trabalhava, como fez a acusação, mas a partir de provas admitidas em direito. A coerência entre o resultado obtido e o modos operandi pressuposto pela acusação apenas demonstra a coerência de sua tese, mas não a comprova. Inexistentes esses resultados, a teoria não seria nem mesmo crível. Por esse motivo, o fato de os outros indiciados que teriam se beneficiado dessa especificação "não conforme" das ordens serem pessoas necessárias à implementação dessa especificação vai ao encontro da tese da acusação, mas também não é prova ${ }^{95}$.

Ainda, o Diretor Luiz Antônio Campos dá uma aula sobre o assunto constante em seu voto no PAS CMV nº RJ2002/2405 - afirmando, também, que, diferentemente de outras espécies de prova, a análise dos indícios requer um zelo especial (com grifos):

A mera plausibilidade teórica de que determinada situação ocorra ou tenha ocorrido não autoriza nem acusação, que dirá condenação. E a só lembrança dessa

95 Extrato da Sessão de Julgamento do Processo Administrativo Sancionador CVM no 09/04. Diretor-Relator: Pedro Oliva Marcilio de Sousa. Presidente da sessão de julgamento: Marcelo Fernandez Trindade. Data de Julgamento: 20.06.2006. Disponível em: <http://www.cvm.gov.br/export/sites/cvm/sancionadores/sancionador/anexos/2006/20060620_PA S 0904.pdf>. Acesso em: 10.10.2017. 
situação causa arrepios, pois todo o esforço do Estado de Direito é para se evitar possibilidades deste jaez, cujos resultados são conhecidos e deram origem, não faz tanto tempo assim, a episódios que a história prefere esquecer, como gulags e que tais.

(...)

Portanto, sempre que a questão não seja estreme de dúvidas e que dos fatos possam decorrer mais de uma explicação ou interpretação, não se pode, sob pena de afronta a regras legais e constitucionais, adotar aquela que é mais prejudicial ao acusado, afastando-se as hipóteses que lhe seriam mais benéficas, notadamente quando se trata de processo baseado exclusivamente em indícios.

(...)

Em função destes fatos, tanto a doutrina quanto a jurisprudência já apontaram que os indícios devem ser examinados com redobrada cautela, porque, muitas vezes, sob o pretexto de haver indícios, há apenas conjecturas, suspeitas, suposições, juízos preconcebidos, preconceitos, mas que não encontram respaldo nas provas dos autos ${ }^{96}$.

Além disso, a prova indiciária somente é suficiente para justificar a condenação do acusado quando além de existente um conjunto de indícios da atuação do acusado que, também, não existam contra indícios que lancem dúvidas sobre a responsabilidade do mesmo ${ }^{97}$. Assim, com a apresentação pelo investigado de contra indícios suficientes para enfraquecer a tese acusatória, impõe-se a absolvição do investigado, conforme esclarece a Diretora Norma Parente no âmbito do PAS nº 06/95 (destacou-se):

Os indícios possuem valor probatório suficiente para ensejar condenação. Exigese, todavia, que tais indícios sejam convergentes e unívocos. $\underline{\text { A existência de }}$ contraindícios suficientes para inspirar dúvida nos julgadores deve conduzir à absolvição, em homenagem ao princípio da presunção de inocência ${ }^{98}$.

Nessa mesma linha, conclui-se que os indícios devem ser apreciados com muita cautela pelo julgador, principalmente quando se comparado com

96 Extrato da Sessão de Julgamento do Processo Administrativo Sancionador CVM no TARJ2002/2405. Diretora-Relatora: Norma Jonssen Parente. Relator do Voto Vencedor: Luiz Antonio De Sampaio Campos. Presidente da sessão de julgamento: Wladimir Castelo Branco Castro. Data de Julgamento: 09.10.2003. Disponível em: <http://www.cvm.gov.br/export/sites/cvm/sancionadores/sancionador/anexos/2003/20031009_PA S_RJ20022405.pdf>. Acesso em: 10.10.2017.

${ }^{97}$ EIZIRIK, Nelson; GAAL, Ariádna B.; PARENTE, Flávia; HENRIQUES, Marcus de Freitas. Mercado de capitais - regime jurídico. p. 339.

98 Extrato da Sessão de Julgamento do Processo Administrativo Sancionador CVM nº 06/95. Diretora-Relatora: Norma Jonssen Parente. Presidente da sessão de julgamento: Marcelo Fernandez Trindade. Data de Julgamento: 05.05.2005. Disponível em: 〈http://www.cvm.gov.br/sancionadores/sancionador/anexos/2005/20050505_PAS_0695.pdf>.

Acesso em: 10.10.2017. 
a apreciação de provas diretas - até porque, muitas decisões fundamentadas em provas indiretas se relevam equívocos ${ }^{99}$.

Ainda assim, não há dúvidas sobre a possibilidade da utilização da prova indiciária para justificar a decisão. Nesse mesmo sentido, conclui o Diretor Roberto Tadeu Fernandes, no PAS CVM nº RJ2013/9904, ao afirmar que a prova indiciária equivale a qualquer outro meio de prova, sendo válida para fundamentar uma decisão a luz do princípio do livre convencimento do juiz:

Por ser equivalente a qualquer outra, a prova indiciária é perfeitamente válida para a condenação, dado o princípio do livre convencimento do julgador, que $\underline{\text { deve fundamentar sua decisão }}^{100}$.

Mais do que isso, a prova indiciária é admitida como fundamento único para a condenação, inclusive como textualmente expresso nas seguintes decisões do Supremo Tribunal Federal:

EMENTA: HABEAS-CORPUS. Tráfico de entorpecente. Indícios. Inexistência de causa para condenação. Artigos 157 e 239 do CPP. Os indícios, dado ao livre convencimento do Juiz, são equivalentes a qualquer outro meio de prova, pois a certeza pode provir dele ${ }^{101}$.

1. O principio processual penal do favor do rei não ilide a possibilidade de utilização de presunções hominis ou facti, pelo juiz, para decidir sobre a procedência do ius puniendi, máxime porque o Código de processo penal prevê expressamente a prova indiciária, definindo-a no art. 239 como "a circunstância conhecida e provada, que, tendo relação com o fato, autorize, por indução, concluir-se a existência de outra, ou outras circunstâncias." Doutrina (LEONE, Gionanni. Trattato di Diritto Processuale Penale. V.II. Napoli: Casa Editrice Dott. Eugenio Jovene, 1961. P.161-162) Precedente (HC 96062, Relator(a): Min. Marco Aurélio, Primeira Turma, julgado em 06.10.2009, Dje-213 DIVULG 1211- 2009 PUBLIC 12-11-2009 EMENT VOL-02382-02 PP-00336). 2. O julgador pode, através de um fato devidamente provado que não constitui elemento do tipo penal, mediante raciocínio engendrado com supedâneo nas suas

${ }^{99}$ EIZIRIK, Nelson; GAAL, Ariádna B.; PARENTE, Flávia; HENRIQUES, Marcus de Freitas. Mercado de capitais - regime jurídico. p. 339.

100 Extrato da Sessão de Julgamento do Processo Administrativo Sancionador CVM $n^{\circ}$ RJ2013/9904. Diretor-Relator e Presidente da sessão de julgamento: Roberto Tadeu Antunes Fernandes. Data de Julgamento: 28.04.2015. Disponível em: <http://www.cvm.gov.br/export/sites/cvm/sancionadores/sancionador/anexos/2015/20150428 PA S_RJ20139904.pdf>. Acesso em: 30.10.2017.

${ }^{101}$ BRASIL. Supremo Tribunal Federal (STF). Habeas Corpus n ${ }^{\circ}$ 70344/RJ. Relator: Ministro Paulo Brossard. Data de Julgamento: 14.09.1993. Segunda Turma. Data de Publicação: DJ 22-10-1993. 
experiências empíricas, concluir pela ocorrência de circunstância relevante para a qualificação penal da conduta ${ }^{102}$.

Nessa mesma linha, o Ministro Luiz Fux do Supremo Tribunal Federal confirmou a possibilidade de utilização de prova indiciária para a responsabilização da prática de insider trading, no âmbito da Ação Penal no 470, conforme trecho a seguir transcrito (destacou-se):

No mesmo diapasão é a prova dos crimes e infrações no mercado de capitais. São as circunstâncias concretas, mesmo indiciárias, que permitirão a conclusão pela condenação. Na investigação de insider trading (uso de informação privilegiada e secreta antes da divulgação ao mercado de fato relevante): a baixa das ações, a frequência com que são negociadas, ser o acusado um neófito em operação de bolsa; as ligações de parentesco e amizade existente entre os acusados e aqueles que tinham contato com a informação privilegiada; todas estas e outras são indícios que, em conjunto, permitem conclusão segura a respeito da ilicitude da operação $^{103}$.

Ressaltamos, ainda, que a importância da prova indiciária para a condenação pela prática de insider trading, principalmente quando se trata de insider de mercado, já foi reconhecida pela Comissão de Valores Mobiliários. No PAS CVM nº 25/2010, o Diretor Henrique Balduino explica a relevância da prova indiciária diante de casos nos quais não é possível obter prova direta (destacou-se):

Como se vê, a utilização da prova indiciária é de especial importância em contextos de infrações nas quais nem sempre é possível obter uma prova direta dos envolvidos no momento exato do cometimento do ilícito, que, no presente caso, poderia advir de uma gravação telefônica dos Acusados discutindo o teor da relevância e do sigilo da informação ainda não divulgada ao mercado ${ }^{104}$.

Mais do que isso, no PAS CVM no 13/09, o Diretor Eli Loria esclareceu que, muitas vezes, a prova indiciária é o único caminho a ser

\footnotetext{
${ }^{102}$ BRASIL. Supremo Tribunal Federal (STF). Habeas Corpus $\mathrm{n}^{\circ}$ 113.118/SP., Relator: Ministro Luiz Fux. Data de Julgamento: 20.03.2012. Primeira Turma. Data de Publicação: DJe-081 Divulgação: 25.04.2012; Publicação: 26/04/2012. DJe-081.

${ }^{103}$ BRASIL. Supremo Tribunal Federal $(S T F)$. Ação Penal: 470 Minas Gerais, Relator: Ministro Roberto Barroso. Data de Julgamento: 10.02.2015. Data de Publicação: DJe-032 Divulgação: 18.02.2015; Publicação: 19/02/2015.

${ }^{104}$ Extrato da Sessão de Julgamento do Processo Administrativo Sancionador CVM no 25/2010. Diretor-Relator: Henrique Balduino Machado Moreira. Presidente da sessão de julgamento: Leonardo P. Gomes Pereira. Data de Julgamento: 04.07.2017. Disponível em: 〈http://www.cvm.gov.br/export/sites/cvm/sancionadores/sancionador/anexos/2017/25_2010.pdf >. Acesso em: 10.10.2017.
} 
seguido para comprovar o uso indevido de informação privilegiada quando cometida por insider secundário (com grifos):

Preliminarmente, contudo, gostaria de ressaltar que, como exposto pelo Diretorrelator, nos casos envolvendo insiders secundários, a utilização de indícios na construção da peça acusatória e na eventual condenação dos acusados mostra-se não só como um caminho natural, mas, muitas vezes, como o único caminho a ser seguido; isso porque penso que a prova definitiva e irrefutável da prática de insider de mercado é bastante complexa, exceto se, de alguma forma, o vínculo ficar claramente evidente, como ocorreria na hipótese de haver uma confissão, por exemplo. Entendo, assim, possível que uma condenação seja baseada em prova indiciária, formada por um conjunto de indícios sérios, consistentes e convergentes, e respeitado o princípio do livre convencimento motivado do julgador e essas provas indiciárias são, inclusive, reconhecidas expressamente pelo art. 239 do Código de Processo Penal ${ }^{105}$.

A verdade é que a prática de insider trading, em razão de sua natureza, dificilmente poderá ser comprovada através de prova direta de sua ocorrência. Ainda assim, o referido ilícito deixa um rastro farto de indícios ${ }^{106}$.

Dessa forma, ainda que importante em todo caso, a utilização da prova indiciária é essencial na condenação do insider de mercado. Isso porque, como já explicado, em relação ao insider primário existem presunções, que acabam por "facilitar" o papel da acusação na comprovação dos elementos que configuram a negociação de valores mobiliários com a utilização de informação privilegiada.

É evidente que a prova indiciária também será utilizada na comprovação de elementos para configuração da utilização de informação privilegiada em casos de insiders primários. Mas, como nesses casos, de acordo com o entendimento da Comissão de Valores Mobiliários, existem

\footnotetext{
105 Extrato da Sessão de Julgamento do Processo Administrativo Sancionador CVM no 13/09. Diretor-Relator: Eli Loria. Presidente da sessão de julgamento: Maria Helena dos Santos Fernandes de Santana. Data de Julgamento: 13.12.2011. Disponível em: <http://www.cvm.gov.br/export/sites/cvm/sancionadores/sancionador/anexos/2011/20111213 PA S 1309.pdf>. Acesso em: 10.10.2017.

${ }^{106}$ PARENTE, Norma Jonssen. Tratado de Direito Empresarial - Volume VI - Mercado de Capitais. p. 17.
} 
presunções de alguns elementos do tipo, a utilização de indícios não é tão necessária para fundamentar a acusação e, posterior, condenação do acusado.

Nesse sentido, no PAS CVM no 13/2000, a Diretora Norma esclarece que, diferentemente dos insiders primários (em relação aos quais existem presunções relativas), para comprovação de que insiders secundários negociaram com a utilização de informações privilegiadas é necessária a existência de indícios que permitam essa conclusão pelo julgador (grifou-se):

Embora seja verdade que a presunção em se tratando de administrador é "iuris tantum", nada impede que se presuma a culpa do "tippee" ou do "insider de mercado", havendo indícios que façam supor que o mesmo comprou ou vendeu ações no mercado com informação privilegiada. A presunção decorre do convencimento do julgador a partir de indícios fortes e concorrentes.

(...)

Assim, mesmo em se tratando de não administrador, o "insider trading" pode e deve ser reconhecido se os indícios levarem a essa conclusão. Portanto, entendo que a partir de indícios graves, precisos e concorrentes se possa também presumir a responsabilidade de não administradores, ainda que não decorra da presunção "iuris tantum"107.

Inclusive, o Diretor Gustavo Borba, citando o voto da Diretora Norma Parente transcrito acima, concluiu, no âmbito do julgamento do PAS CVM nº RJ2013/1730, que por se tratar de insider secundário não foram apresentados indícios suficientes para a condenação do acusado - impondose, portanto, a absolvição do mesmo (destacou-se):

Em relação ao acusado, contudo, por ser um eventual insider secundário, haveria necessidade de que fossem apuradas outras evidências ou indícios coincidentes que, no seu conjunto, conduzissem à conclusão de que ele teria ciência desse fato relevante (na linha defendida pela Ex-Diretora Norma Parente no Inquérito Administrativo CVM 13/2000 e hoje adotada pelo Colegiado da CVM). $\underline{\mathrm{O}}$ processo, contudo, não foi conduzido de forma a que se obtivessem outros

${ }^{107}$ Extrato da Sessão de Julgamento do Processo Administrativo Sancionador CVM no 13/2000. Diretor-Relator: Marcelo Fernandes Trindade. Presidente da sessão de julgamento: Norma Jonssen Parente. Data de Julgamento: 17.04.2002. Disponível em: <http://www.cvm.gov.br/export/sites/cvm/sancionadores/sancionador/anexos/2002/20020417 PA

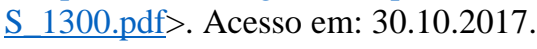


indícios complementares sobre o acesso à informação privilegiada, o que impede a aplicação de punição ao acusado ${ }^{108}$.

Pois bem, por um lado, fica claro a essencialidade da prova indiciária como meio eficaz para a condenação de acusados pela prática de condutas delituosas, especialmente, o uso indevido de informações privilegiadas no âmbito da Comissão de Valores Mobiliários. Por outro lado, e mesmo com a equivalência de todos os meios de prova previstos e permitidos no ordenamento brasileiro, a análise da prova indiciária e dos indícios, um a um, requer uma atenção adicional.

Para a condenação, seja pela prática de insider trading ou qualquer outro ilícito, com fundamento em prova indiciária, é necessária a presença de indícios múltiplos, veementes, convergentes e graves, sendo suficientes para configurar mais do que uma mera conjectura, e capazes de formar o convencimento do juiz de forma a superar a dúvida razoável. Além disso, não deverá existir, nos autos do Processo Sancionador, contra indícios que enfraqueçam os indícios apresentados pela tese acusatória.

108 Extrato da Sessão de Julgamento do Processo Administrativo Sancionador CVM $\mathrm{n}^{\circ}$ RJ2013/1730. Diretora-Relatora: Luciana Dias. Declaração de Voto: Gustavo Tavares Borba Presidente da sessão de julgamento: Leonardo P. Gomes Pereira. Data de Julgamento: 18.08.2015. Disponível 


\section{INDÍCIOS E CONTRA INDICÍOS DA PRÁTICA DE INSIDER TRADING}

Por tudo visto no Capítulo anterior, é inegável a importância da prova indiciária na responsabilização pela prática de insider trading. Assim, no presente Capítulo serão apresentados e analisados os principais indícios, bem como os contra indícios, comumente utilizados pelo Colegiado da Comissão de Valores Mobiliários para justificar a condenação e a absolvição dos acusados pela prática do referido ilícito.

Nesse ponto, não analisaremos nenhuma espécie de prova direita para a configuração dos elementos do tipo, ou para a comprovação da ausência de qualquer dos elementos do tipo.

Além disso, para fins do presente Capítulo só foram analisados Processos Sancionadores de apuração da prática de insider trading julgados no âmbito da Comissão de Valores Mobiliários. Ou seja, não serão analisados os julgamentos de Processos Sancionadores em fase recursal, no âmbito do Conselho de Recursos do Sistema Financeiro Nacional, bem como, Processos Judiciais a respeito do tema.

Ainda, tendo em vista a constante mudança dos integrantes do Colegiado da Comissão de Valores Mobiliários, foram privilegiados os precedentes mais recentes da prática de insider trading - principalmente, os Processos Sancionadores julgados nos últimos 5 (cinco) anos.

\subsection{Lógica Comum}


Como sabemos, o investimento no mercado de capitais é uma aposta, e como toda aposta, é marcado pelo risco. Assim, independentemente do quão qualificado é o investidor, um investimento pode gerar lucro ou prejuízo, pois não é possível ter a certeza do seu resultado, em razão de todas as variáveis que o afetam. Bom, e se tivéssemos a quase certeza de que o investimento geraria lucro ou de que seria possível evitar prejuízo?

Nesse sentido, a análise das características da transação suspeita, bem como, a análise comportamental do investigado, é parte essencial da investigação realizada pela Comissão de Valores Mobiliários para apuração da prática de insider trading.

A partir dessas análises é possível extrair, por exemplo, a existência (ou não) da intenção de auferir vantagem indevida pelo investigado, bem como, se, no melhor conhecimento do investigado, a informações por ele detida era relevante ou não. Inclusive, como confirma o trecho abaixo (com grifos):

Although proving a defendant's intent presents difficulties in some cases, the difficulties are not insurmountable. The defendant's activities often will indicate whether, in his opinion, the information in his possession was material to the valuation of the security. If the trading record of the defendant demonstrates that the transaction that forms the basis of the complaint is not unusual for him, carries an equal amount of risk, and involves a similar amount of money as in other transactions performed by him, then proving an intent to trade on inside information is more difficult. If, however, as is most often the case, the transaction is usually large, carries a high degree of risk, and is unusually profitable, then proof of intent is much easier. A judge or jury may not be easily convinced of a lack of intent to trade on inside information (provided that the judge or jury is familiar with the operation of capital markets - see section 2.7.3.) when, for example, the defendant opened a new investment account, acquired shares of one company for an amount equal to twice his yearly income, and earned an enormous profit when the price of the shares rose upon publication of inside information that was in his possession prior to his acquisition of the shares. In such circumstances, a defendant's argument that he did not realize that the information in his possession was material, confidential, inside information is not very tenable $\mathrm{e}^{109}$.

${ }^{109}$ INTERNATIONAL ORGANIZATION OF SECURITIES COMMISSIONS - IOSCO. Insider Trading - How Jurisdictions Regulate It. Março de 2003. Disponível em: 〈www.iosco.org〉. Acesso em: 30.10.2017. 
Apenas para fins de ilustração, pois essas questões ainda serão apresentadas uma a uma, as seguintes anormalidades são algumas das exploradas no âmbito do julgamento de Processos Sancionadores: (i) volume muito superior da transação, quando comparado com transações anteriores; (ii) operações a termo, que indicam a urgência das mesmas; e (iii) concentração de recursos em negociação com determinado valor mobiliário.

É obvio que com a clareza de um investimento certo, o que se espera em relação ao homem racional é a tomada de determinadas medidas com o objetivo de potencializar o possível lucro ou evitar ao máximo o possível prejuízo. Medidas essas que formam o carro chefe da Comissão de Valores Mobiliários para acusar e, posteriormente, condenar investidores pela prática de insider trading.

Nessa mesma linha, conclui o Diretor Henrique Balduino pela importância da análise do comportamento do investigado como investidor racional para comprovar os elementos que configuram a prática de insider trading, principalmente, quando se trata de insider de mercado (com grifos):

66. Em casos que tais [de insider secundário], é o comportamento extraordinariamente atípico do investidor que demonstra (i) o acesso a informação e (ii) o conhecimento de sua natureza privilegiada, previamente à tomada de decisão de investimento. Trata-se, portanto, de comprovar que a conduta praticada pelo acusado, quando comparada àquela esperada de um investidor racional, é justificada tão somente quando se admite presente o elemento informacional que o coloca em posição não equitativa com os demais participantes do mercado $^{110}$.

Dessa forma, toda conduta do investidor que não fizer sentido do ponto de vista do homem racional que negocia com valores mobiliários, poderá ser considerada pela Comissão de Valores Mobiliários como um indício da utilização de informação privilegiada. E, por outro lado, toda

${ }^{110}$ Extrato da Sessão de Julgamento do Processo Administrativo Sancionador CVM no 25/2010. Diretor-Relator: Henrique Balduino Machado Moreira. Presidente da sessão de julgamento: Leonardo P. Gomes Pereira. Data de Julgamento: 04.07.2017. Disponível em: 〈http://www.cvm.gov.br/export/sites/cvm/sancionadores/sancionador/anexos/2017/25_2010.pdf >. Acesso em: 10.10.2017. 
conduta que for condizente com a atitude do investidor racional poderá ser utilizada como um contra indício da prática do referido ilícito.

Bom, é evidente que quanto mais incomum for a conduta do investigado quando comparado ao investidor racional e, também, quando comparado às condutas passadas do próprio investigado, maior a probabilidade de este ter se utilizado de informação privilegiada para negociar com o valor mobiliário objeto da transação.

Essa lógica, de comparação da conduta do investigado com o investidor racional, é aplicada pela Comissão de Valores Mobiliários com relação a diversos indícios e contra indícios, podendo ser entendida praticamente como uma regra geral aplicável para a fundamentação da condenação ou da absolvição dos acusados com base em indícios e/ou contra indícios.

Além disso, a Comissão de Valores Mobiliários criou a terminologia conduta típica e conduta atípica de insider trader. Além de comuns a vários precedentes de insider trading, as condutas típicas são aquelas que se justificam, especialmente, para o investidor na posse de informação privilegiada. E, nesse sentido, condutas típicas constituem alguns dos indícios utilizados pelo Colegiado para condenar acusados pelo uso indevido de informação privilegiada.

Por outro lado, as condutas atípicas são aquelas que não fazem sentido do ponto de vista daquele investidor na posse de informação privilegiada. Dessa forma, as condutas atípicas constituem alguns dos contra indícios utilizados pelo Colegiado para absolver acusados pelo uso indevido de informação privilegiada.

Enfim, exploradas essas considerações comuns aos precedentes de apuração da prática de insider trading no âmbito da Comissão de Valores 
Mobiliários, passaremos para uma análise mais detalhada de alguns dos indícios e contra indícios usualmente presentes nos Processos Sancionadores.

\subsection{Indícios e Contra Indícios Usuais em Processos Sancionadores}

Agora, analisaremos os indícios/contra indícios normalmente considerados pelo Colegiado da Comissão de Valores Mobiliários tanto para condenar como para absolver os acusados pela prática insider trading, separados nos seguintes tópicos: (i) timing perfeito; (ii) relações pessoais; (iii) perfil de negociação; e (iv) demais condutas do investidor.

Ressaltamos, ainda, que apesar dos indícios serem analisados separadamente para fins do presente item do Capítulo, na fundamentação da acusação, condenação ou absolvição pela Comissão de Valores Mobiliários, os indícios e contra indícios sempre serão analisados conjuntamente. Até porque, como já visto no Capítulo anterior para fundamentar a condenação pela prática de insider trading, é necessária a existência de indícios múltiplos, graves, veementes e convergentes.

Assim, apresentaremos a análise isolada dos indícios considerados pela Comissão de Valores Mobiliários para fundamentar suas decisões deixando claro que, no âmbito dos Processos Sancionadores nos quais a prova indiciária foi utilizada para fundamentar a decisão, sempre haverá um aglomerado de indícios/contra indícios analisados de forma conjunta.

\subsubsection{Timing Perfeito}

Primeiramente, exploraremos o indício comumente denominado timing perfeito, através do qual a Comissão de Valores Mobiliários analisa o momento da negociação, seja compra e/ou venda, realizada pelo investigado. Bom, se o insider trader é aquele que, em razão de uma informação privilegiada, possui uma vantagem sobre os outros investidores, é evidente que ele detém uma melhor compreensão do momento ideal para negociar 
com determinado valor mobiliário, de modo a potencializar seus ganhos ou reduzir suas perdas.

Nesse sentido, a relevância da análise do timing das negociações em precedentes de insider trading já foi confirmada pela Comissão de Valores Mobiliários. Nas palavras da Diretora Luciana Dias (destacou-se):

38. A Acusação está correta em utilizar o timing das operações como um balizador. Nas negociações de ações em que há informação privilegiada, os investidores desejam se posicionar nos papéis antes de eventos sobre os quais têm conhecimento de dados sigilosos. Como nesses casos é muito difícil a obtenção de uma prova direta, o "momento" de aquisição ou venda do papel é muito importante na avaliação de utilização indevida de informação privilegiada ${ }^{111}$.

O melhor momento para a negociação de valor mobiliário de emissão de determinada companhia, quando há informação relevante não divulgada ao mercado, depende, em primeiro lugar, do conteúdo da informação.

Ainda que não seja possível prever a reação do mercado em relação à informação relevante divulgada, existe uma tendência de que a divulgação de informação boa ocasione a alta na cotação de valores mobiliários afetados por tal informação, enquanto a divulgação de uma informação ruim gere queda na cotação de valores mobiliários afetados por tal informação. No caso, partimos do conceito de bom e ruim decorrente do senso comum, sem adentrar nas possíveis particularidades da divulgação pela companhia de informações complexas.

Nesse sentido, o timing típico do insider trader, quando da divulgação pela companhia de informação boa, é caracterizado pela compra logo antes da divulgação da informação e pela venda logo após a divulgação da informação. Desse modo, é possível comprar valores mobiliários "na

111 Extrato da Sessão de Julgamento do Processo Administrativo Sancionador CVM no 11/08. Diretora-Relatora: Luciana Dias. Presidente Interino da sessão de julgamento: Otavio yazbek. Data de Julgamento: 21.08.2012. Disponível em: <http://www.cvm.gov.br/export/sites/cvm/sancionadores/sancionador/anexos/2012/20120821_PA S 1108.pdf>. Acesso em: 10.10.2017. 
baixa", pois o valor não reflete a precificação da informação privilegiada pelo mercado, e aproveitar a alta da cotação dos valores mobiliários para vender, potencializando o lucro da referida transação.

Nesse ponto, esclarece o Diretor Henrique Balduino que esse timing típico é um indício da intenção de auferir vantagem, que é elemento essencial para a configuração da prática de insider trading (com grifos):

Cabe consignar, em adição, que a estratégia de comprar pouco antes do fato relevante e vender logo em seguida à sua divulgação, aproveitando a valorização decorrente desta divulgação, é mais um indício que se soma aos demais na direção de que os Acusados atuaram com a intenção de auferir vantagem econômica, comportamento típico de um investidor que busca retorno rápido, característica notória de quem age de posse de uma informação privilegiada ${ }^{112}$.

Apesar do timing descrito acima, a realização de qualquer uma das operações isoladas, seja a compra logo antes da divulgação da informação ou a venda logo após a divulgação da informação, também pode constituir indício da prática de insider trading, quando analisado em conjunto com outras circunstâncias do caso concreto.

Até porque é entendimento pacífico do Colegiado da Comissão de Valores Mobiliários que a manutenção (isto é, quando não há venda) dos valores mobiliários adquiridos com a utilização de informação privilegiada não é capaz de descaracterizar a prática do ilícito insider trading.

Ainda assim, a manutenção dos valores mobiliários adquiridos é considerada pela Comissão de Valores Mobiliários como um contra indício da realização de negociação com utilização de informação privilegiada. Nesse sentido, no PAS CVM n ${ }^{\circ}$ RJ2012/9808, os acusados foram absolvidos, dentre outros motivos, pela manutenção dos valores mobiliários (grifou-se):

${ }^{112}$ Extrato da Sessão de Julgamento do Processo Administrativo Sancionador CVM no 25/2010. Diretor-Relator: Henrique Balduino Machado Moreira. Presidente da sessão de julgamento: Leonardo P. Gomes Pereira. Data de Julgamento: 04.07.2017. Disponível em: 〈http://www.cvm.gov.br/export/sites/cvm/sancionadores/sancionador/anexos/2017/25_2010.pdf >. Acesso em: 10.10.2017. 
47. O Acusado tampouco vendeu as ações da Sanepar logo após a divulgação do Fato Relevante, quando poderia obter lucro imediato, mas optou por permanecer com elas até o pregão do dia 18.09.13, quando então se desfez da sua posição acionária.

48. Devo reconhecer que este não é o comportamento típico de um insider trading.

49. O padrão de negociação esperado de um investidor que negocia mediante o uso de informação relevante ainda não divulgada seria o de adquirir a maior quantidade possível de ações antes da divulgação do fato relevante, para vendêlas logo após a disseminação da informação ao mercado, objetivando, com isso, o melhor retorno para o investimento.

(...)

58. O Acusado Joel Musman tampouco se desfez de sua posição na Sanepar após a divulgação do Fato Relevante de 16.02.12, quando poderia obter retorno rápido e garantido; ao contrário, permaneceu de posse das ações até pelo menos o pregão de 30.09.15 (o último pregão do qual se dispõe de informação nestes autos).

(...)

118. A maior concentração de aquisições nas ações da Sanepar posteriormente à divulgação do Fato Relevante e a manutenção delas em carteira por um longo período são contraindícios importantes e aptos a enfraquecer a tese acusatória de ocorrência do insider trading. ${ }^{113}$

Já o timing típico de insider trader, quando da divulgação pela companhia de informação ruim, é caracterizado pela venda antes da divulgação da informação, de forma a evitar prejuízo decorrente da desvalorização na cotação do valor mobiliário após a divulgação da informação.

No PAS CVM n ${ }^{\circ}$ RJ2012/7880 ${ }^{114}$, a acusação foi baseada no fato de o acusado ter vendido as ações de titularidade da sua empresa antes da divulgação de fato relevante por companhia na qual era vice-presidente do Conselho de Administração (destacou-se):

113 Extrato da Sessão de Julgamento do Processo Administrativo Sancionador CVM $\mathrm{n}^{\circ}$ RJ2012/9808. Diretor-Relator: Roberto Tadeu Antunes Fernandes. Presidente da sessão de julgamento: Leonardo P. Gomes Pereira. Data de Julgamento: 18.12.2015. Disponível em: <http://www.cvm.gov.br/export/sites/cvm/sancionadores/sancionador/anexos/2015/20151218_PA S_RJ20129808.pdf >. Acesso em: 10.10.2017

${ }^{114}$ No PAS CVM n ${ }^{\circ}$ RJ2012/7880, o acusado (Rafael Palladino) foi condenado, por ter negociado com ações de emissão do Banco Panamericano S.A., com o uso da empresa Max Control Assessoria e Investimento Ltda., da qual era proprietário, nos dias 24 e 28.09.10 e 07.10.10, antes da publicação do Fato Relevante em 09.11.10, em infração ao artigo 13, caput, da Instrução CVM no 358 , combinado com o $\S 1^{\circ}$ do artigo 155 da Lei $n^{\circ}$ 6.404, à pena de multa no valor de 877.200,00, correspondente ao triplo da perda evitada, na forma do inciso II do artigo 11 da Lei $\mathrm{n}^{\circ}$ 6.385, combinado com o inciso III do $\S 1^{\circ}$ do mesmo artigo. 
Rafael Palladino foi acusado pela utilização indevida de informação privilegiada, em infração ao disposto no artigo 13, caput, da Instrução CVM n ${ }^{\circ} 358 / 02$, combinado com o $\S 1^{\circ}$ do artigo 155 da Lei $n^{\circ}$ 6.404/76, pois se utilizou da Max Control Assessoria e Investimentos Ltda. ("Max Control"), empresa da qual era o proprietário, para negociar com ações de emissão do Banco Panamericano S/A (" Panamericano"), do qual era Vice-Presidente do Conselho de Administração e Diretor Superintendente.

A acusação se baseia no fato de que a Max Control vendeu ações de emissão do Panamericano, nos dias 24 e 28.09 .10 e 07.10.10, antes da divulgação ao mercado do Fato Relevante publicado em 09.11.10, que noticiou o aporte de $\mathrm{R} \$ 2,5$ bilhões realizado pelo Grupo Silvio Santos, na qualidade de principal acionista controlador do Panamericano, recursos obtidos mediante operação financeira contratada com o FGC - Fundo Garantidor de Créditos.

Concluiu a acusação que a Max Control, ao vender 85.000 ações naqueles dias, por um preço médio unitário de $\mathrm{R} \$ 8,21$, evitou um prejuízo de $\mathrm{R} \$ 292.400,00$, valor a menor que teria auferido caso realizasse as vendas por $\mathrm{R} \$ 4,77$, preço de fechamento do pregão de 10 de novembro, data seguinte à da publicação do Fato Relevante (lembro que o Fato Relevante foi divulgado após o encerramento do pregão do dia 09 de novembro) $)^{115}$.

Em alguns precedentes da Comissão de Valores Mobiliários, a divulgação da informação ainda é procedida por uma compra, pois se aproveitando da queda na cotação dos valores mobiliários, o insider readquire sua posição acionária por valor inferior ao da venda. Se a venda logo antes da divulgação já é um indício, essa operação de venda seguida de compra tem um peso maior ainda, no entendimento do Colegiado, para justificar a condenação pela prática de insider trading.

Inclusive como esclarece o Diretor Roberto Tadeu Fernandes, no âmbito do PAS CVM nº RJ2014/3552, a venda antes da divulgação de fato relevante, seguida de compra é uma estratégica típica de insider trading, que demonstrar a intenção de auferir vantagem do acusado (com grifos):

A estratégia de vender pouco antes do Fato Relevante e comprar logo em seguida à sua divulgação demonstra que Acusado visou a inequivocamente auferir vantagem patrimonial, comportamento este típico de um investidor que busca

115 Extrato da Sessão de Julgamento do Processo Administrativo Sancionador CVM $\mathrm{n}^{\circ}$ RJ2012/7880. Diretor-Relator: Roberto Tadeu Antunes Fernandes. Presidente da sessão de julgamento: Leonardo P. Gomes Pereira. Data de Julgamento: 13.11.2013. Disponível em: <http://www.cvm.gov.br/export/sites/cvm/sancionadores/sancionador/anexos/2013/20131119_PA S_RJ20127880.pdf>. Acesso em: 10.10.2017. 
retorno rápido, uma das notórias características de quem age como insider trading ${ }^{116}$.

Nesse Processo Sancionador, um dos acusados (Antônio de Agostini) vendeu ações logo antes da divulgação de fato relevante, readquiriu a mesma participação acionária na semana seguinte e, dois meses depois, vendeu novamente ações logo antes da divulgação de outro fato relevante ${ }^{117}$.

Enfim, o momento da negociação dos valores mobiliários pode ser considerado principalmente para comprovar a intenção do acusado em obter vantagem indevida, podendo ser utilizado para justificar a condenação ou a absolvição dos acusados no âmbito de Processo Sancionador, dependendo se enquadram ou não no "timing perfeito" típico dos insiders.

\subsubsection{Relações Pessoais}

Através da análise dos precedentes de insider trading foi possível extrair dois aspectos normalmente analisados pela Comissão de Valores Mobiliários quanto às relações pessoais dos acusados: (i) relação do acusado com possível fonte primária (pessoa que tem acesso a informações diretamente da companhia); e (ii) movimento de pessoas conectadas na negociação de um valor mobiliário específico.

Em ambos os casos, a Comissão de Valores Mobiliários pode e deve explorar todas as formas de relação entre pessoas para justificar a acusação e, posteriormente, a condenação/absolvição dos investigados. Nesse sentido,

\footnotetext{
116 Extrato da Sessão de Julgamento do Processo Administrativo Sancionador CVM $n^{\circ}$ RJ2014/3225. Diretor-Relator: Roberto Tadeu Antunes Fernandes. Presidente da sessão de julgamento: Leonardo P. Gomes Pereira. Data de Julgamento: 13.09.2016. Disponível em: <http://www.cvm.gov.br/export/sites/cvm/sancionadores/sancionador/anexos/2016/20160913 PA

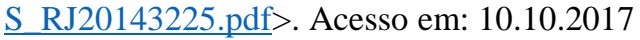

117 No PAS CVM no RJ2014/3552, o acusado (Antônio de Agostini) foi condenado, pelo uso de informação privilegiada na negociação de ações ordinárias da HRT Participações em Petróleo S.A. nos dias 17.07.2013 e 05.09.2013, em infração ao art. $155, \S 4^{\circ}$, da Lei $n^{\circ} 6.404$, combinado com o $\S 1^{\circ}$ do art. 13 da Instrução $C V M n^{\circ} 358$, à pena de multa no valor de $\mathrm{R} \$ 456.560,00$, correspondente a duas vezes o montante da perda evitada.
} 
são analisados laços profissionais, laços de parentesco, laços de amizade, dente outros.

Quanto ao primeiro aspecto, relembramos que para a condenação legítima do insider de mercado, é necessário que se comprove que este obteve acesso a informação relevante não divulgada ao mercado. Ainda que não fique comprovado quem foi o informante ou o caminho que a informação privilegiada percorreu, é indispensável que o efetivo acesso a informação pelo insider secundário seja comprovado, ainda que através indícios.

Pois bem, a existência de relação entre alguém que obteve acesso à informação privilegiada, comprovada ou presumidamente, e o investigado da prática de insider trading é um indício de que este pode ter conhecimento da informação. Ou seja, essa relação representa um possível caminho que a informação percorreu até chegar ao insider secundário.

No PAS CVM no $23 / 10^{118}$, por exemplo, um dos fundamentados da condenação de um dos acusados foi o fato deste estar casado com integrante de família controladora da companhia e que, pessoalmente, detinha participação indireta na mesma:

A outra prova resulta da sua condição de marido de Camila Lacombe Correa Reche, que além de individualmente possuir $6,25 \%$ das cotas da Traninvest, controladora da T\&T, era membro da família Lacombe, controladora da Manasa, pessoa que em razão dessas circunstâncias deteria informações sobre os negócios da Companhia ${ }^{119}$.

\footnotetext{
${ }^{118}$ No PAS CVM n ${ }^{\circ}$ 23/10, o acusado (Luis Roberto Correa Reche) foi condenado, por ter adquirido ações da Manasa Madeireira Nacional S.A. antes da divulgação do Fato Relevante, em infração ao artigo $13, \S 1^{\circ}$, da Instrução CVM n $358 \mathrm{c} / \mathrm{c}$ o $\S 4^{\circ}$, do artigo 155 , da Lei $n^{\circ} 6.404$, à pena de multa no valor de $\mathrm{R} \$ 200.000,00$, na forma do inciso II do artigo 11 da Lei $\mathrm{n}^{\circ} 6.385 \mathrm{c} / \mathrm{c}$ o inciso I do $\S 1^{\circ}$ do mesmo artigo.

119 Extrato da Sessão de Julgamento do Processo Administrativo Sancionador CVM no 23/10. Diretor-Relator: Roberto Tadeu Antunes Fernandes. Presidente da sessão de julgamento: Leonardo P. Gomes Pereira. Data de Julgamento: 04.11.2014. Disponível em: <http://www.cvm.gov.br/export/sites/cvm/sancionadores/sancionador/anexos/2014/20141104_PA S_232010.pdf>. Acesso em: 10.10.2017.
} 
É óbvio que essas relações devem ser consideradas para a formulação da acusação, bem como para justificar a condenação no âmbito do julgamento pelo Colegiado da Comissão de Valores Mobiliários. Ainda assim, o entendimento do Colegiado é que essas relações não são suficientes para comprovar que a informação privilegiada foi repassada e transmitida para o insider de mercado, pois representa apenas um indício do caminho potencialmente percorrido pela informação desde a sua origem até chegar àquele que negociou valores mobiliários utilizando-se informações privilegiadas.

Nessa mesma linha, o voto da Diretora Luciana Dias no âmbito do PAS CVM n 11/09 esclarece que a existência da relação, por si só, deve ser entendida apenas como um elemento adicional para a comprovação do acesso a informação (com grifos):

A existência de relações pessoais entre os envolvidos nas operações investigadas tem sido considerada pelo Colegiado da CVM como elemento adicional na apuração de ilícitos de uso indevido de informação privilegiada. Ela constitui, no geral, um indício adicional que the permite formar convicção sobre a possibilidade de acesso à informação relevante pelos acusados. Quando isoladamente considerada, no entanto, a existência de relações pessoais não é suficiente para comprovar a detenção de informação privilegiada ${ }^{120}$.

Quanto ao outro aspecto comumente analisado pela Comissão de Valores Mobiliários nessa espécie de ilícito, movimento de pessoas conectadas, entende-se que não é necessário que uma das pessoas do grupo seja uma fonte primária (isto é, receba a informação diretamente da companhia).

O simples fato de uma pluralidade de pessoas conectadas realizarem transações com características similares tendo por objeto mesmo valor

120 Extrato da Sessão de Julgamento do Processo Administrativo Sancionador CVM no 11/09. Diretor-Relator: Luciana Dias. Presidente da sessão de julgamento: Maria Helena dos Santos Fernandes de Santana. Data de Julgamento: 03.04.2012. Disponível em: <http://www.cvm.gov.br/export/sites/cvm/sancionadores/sancionador/anexos/2012/20120403_PA S 1109.pdf>. Acesso em: 10.10.2017. 
mobiliário, pode ser considerado como um indício da prática de utilização de informações privilegiadas (logicamente, quando conjugados com outros indícios).

Inclusive, mesmo que não seja possível descobrir a fonte primária (até porque de acordo com o entendimento reiterado do Colegiado, isso sequer seria necessário), esse indício é capaz de demonstrar parte do caminho percorrido pela informação privilegiada. Em outras palavras, ainda que não se consiga identificar a fonte, esse indício evidencia como a informação foi repassada dentro de um grupo de pessoas.

Por exemplo, no PAS CMV n ${ }^{\mathbf{0}} 25 / 2010^{121}$, a relação entre os acusados foi utilizada como um dos fundamentos para a condenação, sendo que nenhum dos acusados foi considerado como fonte primária da informação privilegiada, representando apenas como a informação poderia ter sido repassada (destacou-se):

Diante das relações de sócio mantidas por Frederico Lima e Ailton Santos com a Angá e o timing perfeito das operações realizadas pelo Fundo Angá, a Acusação concluiu que a Angá teria negociado ações ordinárias da Aracruz em nome do Fundo Angá baseada em informações sigilosas ainda não divulgadas sobre à reestruturação da Aracruz.

(...)

Dessa forma, o vínculo existente entre Ailton Santos, Frederico Lima e a Angá, o timing perfeito das operações - compras realizadas antes da divulgação dos fatos relevantes e vendas executadas em seguida às divulgações -, o elevado lucro obtido, a ausência de fundamentação suficiente a justificar a realização da negociação, agravada pela tentativa de falsear a verdadeira intenção subjacente à aquisição, são indícios que, analisados em seu conjunto, permitem concluir com convicção que a Angá negociou de posse de informações privilegiadas relacionadas à reestruturação societária da Aracruz, em infração ao $\$ 4^{\circ}$ do art.

${ }^{121}$ No PAS CMV no 25/2010, os acusados Frederico de Souza Lima, Ailton Amaral Santos e Angá Administração de Recursos Ltda. foram condenados, pelo uso de informação privilegiada na negociação de ações ordinárias da Aracruz Celulose S.A., em infração ao disposto no art. $155,^{\circ} 4^{\circ}$, da Lei $n^{\circ}$ 6.404, combinado com o $\$ 1^{\circ}$ do art. 13 da Instrução CVM n 358 , à pena de multa, respectivamente, no valor de $\mathrm{R} \$ 135.550,00$, correspondente a duas vezes o montante do lucro obtido na operação, $\mathrm{R} \$ 1.315 .944,00$, correspondente a duas vezes o montante do lucro potencial obtido na operação e $\mathrm{R} \$ 596.600,00$, correspondente a duas vezes o montante do lucro potencial obtido na operação. 
155 da Lei ${ }^{\circ} 6.404$, de 1976 , c/c o $\$ 1^{\circ}$ do art. 13 da Instrução CVM n 358 , de $2002 . .^{122}$

Acontece que, na prática, esse indício também é utilizado para a absolvição "em massa" dos acusados de um mesmo Processo Sancionador no âmbito da Comissão de Valores Mobiliários. Por vezes, quando um dos acusados é absolvido os demais também são, pois, a acusação foi formulada no sentido de que um dos acusados obteve acesso a informação e repassou para os demais. Bom, comprovado que este acusado não obteve acesso à informação privilegiada, não há que cogitar a condenação dos demais.

Nesse mesmo sentido, o Diretor Roberto Tadeu Fernandes entendeu pela absolvição dos acusados, no âmbito do PAS CVM nº RJ2012/9808 123 (com grifos):

O primeiro obstáculo que se opõe à tese da Acusação é que os indícios por ela carreados aos autos não foram suficientes para me convencer que João José teve acesso à informação sigilosa pendente de divulgação, condição obviamente indispensável para que pudesse repassá-la à Acusada e esta, utilizado-a para realizar as negociações.

Ora, se não me foi possível considerar ilícita as operações realizadas por João José, precisamente porque não se comprovou que ele detinha a informação relevante, como posso reconhecer que a Acusada detinha tal informação e dela fez uso nos seus negócios, informação esta supostamente repassada por João José? $^{124}$

Bom, se pessoas de um mesmo grupo realizam uma mesma conduta com caraterísticas similares existe uma probabilidade de que a justificativa para essa conduta seja a mesma. Quanto mais características forem

\footnotetext{
122 Extrato da Sessão de Julgamento do Processo Administrativo Sancionador CVM no 25/2010. Diretor-Relator: Henrique Balduino Machado Moreira. Presidente da sessão de julgamento: Leonardo P. Gomes Pereira. Data de Julgamento: 04.07.2017. Disponível em: 〈http://www.cvm.gov.br/export/sites/cvm/sancionadores/sancionador/anexos/2017/25_2010.pdf >. Acesso em: 10.10.2017.

${ }^{123}$ No PAS CVM nº RJ2012/9808, os acusados Bogari Gestão de Investimentos Ltda. e João José de Araújo Pereira Pavel foram absolvidos da imputação de uso de informação privilegiada ao negociar ações preferenciais da SANEPAR, em suposta infração ao art. 155, §4 $4^{\circ}$, da Lei $n^{\circ} 6.404$, combinado com o $\S 1^{\circ}$, art. 13, da Instrução CVM n 358.

124 Extrato da Sessão de Julgamento do Processo Administrativo Sancionador CVM $\mathrm{n}^{\circ}$ RJ2012/9808. Diretor-Relator: Roberto Tadeu Antunes Fernandes. Presidente da sessão de julgamento: Leonardo P. Gomes Pereira. Data de Julgamento: 18.12.2015. Disponível em: <http://www.cvm.gov.br/export/sites/cvm/sancionadores/sancionador/anexos/2015/20151218_PA S_RJ20129808.pdf>. Acesso em: 10.10.2017.
} 
semelhantes entre transações realizadas por pessoas conectadas, como mesmo valor mobiliário, mesmo timing, mesmo volume de negociações, mesmo perfil de investimento, dentre outras características, maior a probabilidade de que essas pessoas tenham realizado a operação pelo mesmo motivo.

De logo já fica esclarecido que essa justificativa poderá ser legítima, mas também poderá não ser, como é o exemplo da utilização de informações privilegiadas para negociação de valores mobiliários, o que será analisado a luz do caso concreto.

Além disso, em alguns precedentes esses dois aspectos são analisados conjuntamente, seja porque uma das pessoas do grupo possui relação direta com a informação (ou seja, é um insider primário) ou porque uma das pessoas do grupo possui uma relação com aquele que tem acesso a informação diretamente da companhia. Óbvio que isso parece muito abstrato, mas sempre que analisado no caso concreto, em conjunto com outras provas, poderá colaborar na motivação da decisão do Colegiado.

No PAS CVM n n $^{\circ} 11 / 08$, as seguintes relações foram exploradas pela Comissão de Valores Mobiliários para justificar a acusação: (i) relação entre diretor da companhia cujas ações foram objeto das transações investigadas (fonte primária) e diretor de sociedade acusada no âmbito do Processo Sancionador - demonstrando um possível caminho que a informação privilegiada poderia ter percorrido; e (ii) relação profissional entre empregados de sociedade e relação entre alguns dos empregados e seus respectivos familiares - demonstrando como a informação poderia ter sido repassada:

O Sr. D.F., presidente da Suzano, era amigo pessoal do Sr. E.F.M., presidente do Banco Prosper, sendo o Banco o segundo maior investidor em ações da Suzano entre 11.07.2007 e 03.08.2007. Outros contatos entre as famílias controladoras foram verificados, tal como o de Sr. J.C.P.C.P. e Sr. D.F. O Relatório de Inquérito afirma ainda que os contatos entre eles teriam se intensificado na época dos Jogos Pan Americanos, pelo fato de a Suzano ser fornecedora de materiais em tal evento, conforme noticiado em 11.07.2007. 
(...)

O tio e os primos do Sr. Marcelo Rzezinski foram cadastrados em data muito próxima ao início de suas operações (4 dias), tendo o Sr. Paulo Rzezinski declarado que não atuava no mercado de valores mobiliários, que sua compra de ações da Suzano foi um caso isolado e que se tornou cliente do grupo Prosper somente quando da compra de ações SZPQ4, mesmo caso do Sr. Alexandre Rzezinski ${ }^{125}$.

Nesse Processo Sancionador, todos os acusados foram absolvidos pela prática de insider trading. Mas esse fato não reduz a importância da investigação realizada pela Comissão de Valores Mobiliários para identificar as relações pessoais entre os investigados e entre estes e fontes primárias da informação.

Assim, como elemento adicional para a condenação dos acusados pela prática de insider trading, as relações pessoais dos acusados são analisadas principalmente para comprovar o acesso a informação, ainda que de forma potencial.

\subsubsection{Perfil de Negociação}

A Comissão de Valores Mobiliários estabelece um padrão de negociação do acusado, para conferir se a transação suspeita é compatível (ou não) com seu perfil de negociação. Para tanto, são analisadas todas as operações com valores mobiliários do acusado, durante um período de tempo determinado.

Um indício relevante avaliado para estabelecer o perfil de negociação do acusado é a habitualidade. Nesse ponto, investiga-se a assiduidade da negociação com valores mobiliários pelo acusado, tanto em um aspecto geral - isto é, a frequência do investidor no mercado de capitais, quanto em um

\footnotetext{
125 Extrato da Sessão de Julgamento do Processo Administrativo Sancionador CVM no 11/08. Diretora-Relatora: Luciana Dias. Presidente Interino da sessão de julgamento: Otavio yazbek. Data de Julgamento: 21.08.2012. Disponível em: <http://www.cvm.gov.br/export/sites/cvm/sancionadores/sancionador/anexos/2012/20120821_PA S_1108.pdf>. Acesso em: 10.10.2017.
} 
aspecto específico - ou seja, em relação ao valor mobiliário objeto da transação investigada.

Se por um lado, a operação habitual com valores mobiliários, especialmente, se o investidor já negociava com o valor mobiliário objeto da operação suspeita, é contra indício da prática de insider trading. Por outro lado, a repentina negociação com um valor mobiliário específico, especialmente, quando esta configura a estreia do investidor no mercado de capitais, é um indício da utilização de informação privilegiada.

Além disso, os aspectos das negociações do acusado podem e devem ser considerados para a formação do padrão de negociação do acusado. Apenas exemplificando algum desses aspectos, podemos considerar (i) o volume médio das negociações, (ii) predominância de investimentos a longo ou a curto prazo, (iii) valores envolvidos nas transações e (iv) predominância de operações à vista ou a termo no mercado, dentre outros.

Uma vez analisados todos os aspectos de transações do acusado é possível avaliar se a negociação investigada é compatível com seu perfil de negociação. Esclarecendo o óbvio, sempre que houver compatibilidade entre o perfil de negociação do acusado e a negociação suspeita, estamos diante de um contra indício da prática de insider trading.

Por exemplo, no PAS CVM n ${ }^{\circ} 11 / 08^{126}$, além de confirmar a importância da análise do perfil de investimento dos acusados, a Diretora Luciana Dias se utilizou da compatibilidade das negociações investigadas com o perfil de investimentos de alguns dos acusados como um dos fundamentos para absolvição dos mesmos (destacou-se):

Por isso, foi importante analisar o perfil de investimento de cada um dos Acusados e ver se as "apostas" que fizeram eram compatíveis com tal perfil ou

\footnotetext{
${ }^{126}$ No PAS CVM $n^{\circ} 11 / 08$, todos os acusados foram absolvidos pela imputação de utilização indevida de informação privilegiada na negociação de valores mobiliários de emissão da Suzano, em descumprimento ao $\S 4^{\circ}$ do art. 155 da Lei ${ }^{\circ} 6404 / 76$.
} 
se pareciam fruto de algo extraordinário. Isto porque a tendência natural de quem age munido de informação privilegiada é concentrar os investimentos nos ativos cuja valorização é esperada. O fato de o investidor ter agido dentro de seus padrões normais de negociação é um importante contra indício de uso indevido de informação privilegiada.

(...)

Esses dados demonstram que os padrões de negociação do Sr. Marcelo Sharp de Freitas não se alteraram de maneira significativa no período em que a Acusação entende que ele era detentor de informações privilegiadas. Por isso, estou convencida de que é possível que as "apostas" feitas pelo Sr. Marcelo Sharp de Freitas em ações da Suzano podiam decorrer das informações públicas a respeito da consolidação do setor petroquímico, bem como dos "boatos de mercado" sobre possíveis operações societárias que eram comuns à época dos fatos e não de informações privilegiadas.

É possível desenvolver análises similares do padrão de negociações para os acusados Miriam Vianna Vieira, Paulo Edson Henriques dos Santos e Pedro Lopes de Sousa Palhares. Todos já operavam a termo, em padrões similares aos que negociaram em julho de 2007. As "apostas" feitas em ações da Suzano não eram tão significativas se comparadas com o volume de operações a termo ou com o patrimônio desses Acusados. Por isso, estou convencida de que é plausível que tais operações tenham decorrido de informações públicas e boatos ${ }^{127}$.

O Diretor Roberto Tadeu Fernandes realizou o mesmo raciocínio no julgamento do PAS CVM nº RJ2012/9808, para fundamentar a absolvição de acusado, tendo em vista que as transações objeto do Processo Sancionador foram consideradas compatíveis com seu perfil de investimento e padrão de negociação (com grifos):

O Acusado José Renato alega ser investidor contumaz do mercado de valores mobiliários, tendo por hábito monitorar diversas companhias abertas, e que possui perfil agressivo de investimento e utiliza técnicas de análise gráfica para respaldar suas aplicações (fls. 234 e 235).

Ao examinar seus investimentos em bolsa, no período considerado suspeito pela Acusação, de 22.12.11 a 15.02.12, atesto que o Acusado adquiriu mais de $\mathrm{R} \$ 1,6$ milhões em ações de diversas companhias abertas, tais como: Petrobrás SA (código ISIN PETR4), Vale do Rio Doce SA (código ISIN VALE5), Ambev SA (código ISIN AMBV4) e Banco Itaú Unibanco SA (código ISIN ITUB4) (fls. 1.766 a 1.783$)$.

Em linha com seu declarado perfil, o Acusado também vendeu volume igualmente expressivo de ações neste período de quase dois meses, bem como fez uma "trava de alta", utilizando opções de ações da Petrobras, operação com derivativos que consistiu na compra de 7.000 contratos de opção da série

127 Extrato da Sessão de Julgamento do Processo Administrativo Sancionador CVM no 11/08. Diretora-Relatora: Luciana Dias. Presidente Interino da sessão de julgamento: Otavio yazbek. Data de Julgamento: 21.08.2012. Disponível em: <http://www.cvm.gov.br/export/sites/cvm/sancionadores/sancionador/anexos/2012/20120821_PA S 1108.pdf>. Acesso em: 10.10.2017. 
PETRC22 simultaneamente a venda da mesma quantidade de contratos da série PETRC24.

Tudo leva a crer que o Acusado possuía conhecimentos técnicos e recursos financeiros para obter o máximo proveito com a valorização das ações que adviria da divulgação do reajuste das tarifas, porém preferiu destinar tão somente 5\% dos recursos que destinou à aquisição de ações para comprar os papeis da Sanepar.

(...)

As negociações com as ações da Sanepar feitas pelo Acusado não divergiram do perfil nem do padrão das suas negociações habituais, tampouco tiveram a intensidade esperada daquele que detém uma informação privilegiada, fatos que não me autorizam considerar tais negociações atípicas ${ }^{128}$.

Por outro lado, quando a negociação investigada representar um ponto fora da curva, uma mudança de comportamento do suspeito em seus hábitos negociais, estamos diante de um indício da utilização de informações privilegiadas.

Nesse ponto, a hipótese mais comum é quando a transação investigada representa a estreia de determinado investidor no mercado de capitais, muitas vezes, inclusive, tendo este se cadastro em uma corretora logo antes da realização da negociação e apenas com o objetivo de realizála. Ou ainda que não a primeira transação do investidor no mercado de capitas, também é suspeito quando a transação investigada é a única transação durante certo período de tempo.

No PAS CVM no 23/10 ${ }^{129}$, por exemplo, a mudança de comportamento do investidor foi considerado indício da prática de insider trading (grifou-se):

Uma prova considerada foi a mudança de comportamento de Luis Roberto, que nunca havia negociado com ações de emissão da Manasa, e nem era um investidor habitual no mercado, pois se comprovou que ele não negociou com nenhuma

\footnotetext{
128 Extrato da Sessão de Julgamento do Processo Administrativo Sancionador CVM $n^{\circ}$ RJ2012/9808. Diretor-Relator: Roberto Tadeu Antunes Fernandes. Presidente da sessão de julgamento: Leonardo P. Gomes Pereira. Data de Julgamento: 18.12.2015. Disponível em: <http://www.cvm.gov.br/export/sites/cvm/sancionadores/sancionador/anexos/2015/20151218 PA S_RJ20129808.pdf>. Acesso em: 10.10.2017

${ }^{129}$ No PAS CVM n $^{\circ}$ 23/10, o acusado (Luis Roberto Correa Reche) foi condenado, por ter adquirido ações da Manasa Madeireira Nacional S.A. antes da divulgação do Fato Relevante, em infração ao artigo $13, \S 1^{\circ}$, da Instrução CVM n $358 \mathrm{c} / \mathrm{c}$ o $\S 4^{\circ}$, do artigo 155 , da Lei $n^{\circ} 6.404$, à pena de multa no valor de R\$200.000,00, na forma do inciso II do artigo 11 da Lei $n^{\circ} 6.385 \mathrm{c} / \mathrm{c}$ o inciso I do $\S 1^{\circ}$ do mesmo artigo.
} 
outra ação no período que denominarei de "vedado", e ao apreciar um período de tempo mais dilatado - dois anos - a acusação constatou que ele realizou apenas onze negócios com opções de Petrobrás e Tele Norte Leste Participações, e nenhuma operação no mercado a vista ${ }^{130}$.

Já no PAS CMV n ${ }^{\circ} 25 / 10^{131}$, os seguintes fatos relacionados com o padrão das negociações foram essenciais para embasar a acusação e, posteriormente a condenação dos investidores: (i) o fato da transação investigada ter sido a estreia dos acusados no mercado de capitais; (ii) o fato de que os acusados se cadastraram em corretora logo antes da realização das transações investigadas; e (iii) o fato de que, mesmo após um excelente resultado do investimento, os acusados não realizaram outras transações no mercado de capitais. Como é possível se extrair do trecho abaixo do referido Processo Sancionador (com grifos):

Segundo a Acusação, eles nunca haviam negociado no mercado de valores mobiliários; Marco Bernardi efetuou cadastro em corretora pouco antes da primeira negociação e Fernando Nascimento o fez no mesmo dia da primeira negociação; ambos realizaram seu primeiro negócio comprando ações ordinárias da Aracruz no dia 19.1.2009, ou seja, às vésperas da divulgação dos fatos relevantes de 19 e 20.1.2009, e figuraram entre os maiores compradores - pessoa natural - da ação; venderam todas as ações adquiridas em 21.01.2009, portanto, no pregão seguinte à publicação dos fatos relevantes e obtiveram retornos espetaculares com a negociação; e, mesmo tendo desempenho excepcional em sua estreia no mercado de capitais, eles jamais efetuaram outro negócio em bolsa $^{132}$.

Naturalmente, a tendência do investidor racional que inicia seu desempenho no mercado de capitais com o pé direito, ou seja, com lucro

${ }^{130}$ Extrato da Sessão de Julgamento do Processo Administrativo Sancionador CVM no 23/10. Diretor-Relator: Roberto Tadeu Antunes Fernandes. Presidente da sessão de julgamento: Leonardo P. Gomes Pereira. Data de Julgamento: 04.11.2014. Disponível em: <http://www.cvm.gov.br/export/sites/cvm/sancionadores/sancionador/anexos/2014/20141104_PA S_232010.pdf>. Acesso em: 10.10.2017.

${ }^{131}$ No PAS CMV no 25/2010, os acusados Marco Antonio Bernardi e Fernando Sérgio Rocha Nascimento foram condenados, pelo uso de informação privilegiada na negociação de ações ordinárias da Aracruz Celulose S.A., em infração ao disposto no art. 155, § $4^{\circ}$, da Lei ${ }^{\circ} 6.404$, combinado com o $\S 1^{\circ}$ do art. 13 da Instrução CVM n 358 , a pena de multa, respectivamente, no valor de $\mathrm{R} \$ 122.959,50$, correspondente a uma vez e meia o montante do lucro obtido na operação, e R\$97.299,00, correspondente a uma vez e meia o montante do lucro obtido na operação.

${ }^{132}$ Extrato da Sessão de Julgamento do Processo Administrativo Sancionador CVM no 25/2010. Diretor-Relator: Henrique Balduino Machado Moreira. Presidente da sessão de julgamento: Leonardo P. Gomes Pereira. Data de Julgamento: 04.07.2017. Disponível em: 〈http://www.cvm.gov.br/export/sites/cvm/sancionadores/sancionador/anexos/2017/25_2010.pdf >. Acesso em: 10.10.2017. 
excepcional, é continuar investindo. No entanto, tal lógica não se aplica caso o investidor estivesse na posse de informação privilegiada - pois, nesse caso, após a divulgação de tal informação, deixaria de existir a principal razão que impulsou o investidor a negociar no mercado de capitais, sendo menor a probabilidade de este continuar investindo.

Pois bem, resumindo o entendimento consolidado da Comissão de Valores Mobiliários quanto à análise da negociação suspeita frente ao perfil de negociação do acusado, quando a transação investigada é compatível com o perfil de negociação do acusado - em relação ao volume, prazo de investimento e outras características da transação, não representando uma mudança comportamental, o Colegiado entende que estamos diante de contra indícios da prática de insider trading.

Agora, quanto mais anormal for conduta do investigado quando comparada com o seu passado - perfil e padrão de negociação - e ao comportamento típico do investidor racional, maior a probabilidade de a transação ter ocorrido em decorrência do uso indevido de informação privilegiada - e, nesse sentido, a Comissão de Valores Mobiliários entende que este é um indício da prática de insider trading. Ainda assim, ressalta-se que sempre será possível justificar uma mudança de comportamento, inclusive como ainda será visto no presente Capítulo.

\subsubsection{Demais Condutas do Investidor}

Além da compatibilidade entre o investimento suspeito e o padrão de negociação do acusado, outras condutas também são exploradas pela Comissão de Valores Mobiliários e entendidas como indícios ou contra indícios da prática de insider trading, como será visto no presente item.

Um bom exemplo de conduta analisada é o apetite extraordinário por determinado valor mobiliário, nesse ponto, a Comissão de Valores Mobiliários investiga se o investidor negociou no mesmo período com outros 
valores mobiliários, ou se concentrou seus investimentos em apenas determinado valor mobiliário ou valores mobiliários de uma determinada companhia.

Nesse sentido, a concentração de investimentos em determinado valor mobiliário ou valores mobiliários de uma determinada companhia é um indício da prática de insider trading - pois, se para o mercado em geral a concentração da carteira de investimentos em apenas um valor mobiliário seria arriscada, para aquele que detém a informação privilegiada é uma forma de aumentar potencialmente a vantagem a ser recebida na transação.

Nesse sentido, no PAS CVM nº 25/2010 ${ }^{133}$, um dos acusados não só concentrou todos os seus investimentos em um valor mobiliário específico, como antes disso, se desfez de toda a sua carteira, apurando prejuízo, e aplicou todo o recurso proveniente dessa alienação na compra de apenas um valor mobiliário específico, em total contraste com o seu perfil de negociação (com grifos):

A SPS apurou que Frederico Lima, sócio-administrador da Angá, teria comprado ações de cinco companhias pelo valor total de $\mathrm{R} \$ 93.885,00$, em 23.6.2008. Em 19.1.2009, pouco antes da divulgação dos fatos relevantes, o investidor teria alienado toda a carteira por $\mathrm{R} \$ 49.745,00$, apurando prejuízo, e teria utilizado os recursos para comprar, no mesmo dia, 9.400 ações ordinárias da Aracruz por $\mathrm{R} \$ 49.760,00$. Em seguida, no dia 21.1.2009, Frederico Lima teria alienado a totalidade das ações ordinárias da Aracruz por 117.535,00, obtendo lucro de $\mathrm{R} \$ 67.775,00(136 \%)$.

(...)

Toda essa desconfiança que pairava sobre a reestruturação, contudo, não causou qualquer hesitação em Frederico Lima, que decidiu vender a totalidade das ações detidas em sua carteira de investimento em ações, apurando importante prejuízo com tal atitude, para reinvestir esses recursos em ações ordinárias da Aracruz. Importante destacar que a venda completa da carteira e a compra das ações da Aracruz ocorreram todas no mesmo dia 19.01.2009, poucas horas antes da divulgação dos fatos relevantes.

A pressa em realizar a negociação fez Frederico Lima atuar, inclusive, de maneira totalmente diversa de seu perfil de investimento em ações, que, como visto no

\footnotetext{
${ }^{133}$ No PAS CMV no 25/2010, a acusada Angá Administração de Recursos Ltda. foi condenada, pelo uso de informação privilegiada na negociação de ações ordinárias da Aracruz Celulose S.A., em infração ao disposto no art. $155,{ }^{\circ} 4^{\circ}$, da Lei $n^{\circ} 6.404$, combinado com o $\$ 1^{\circ}$ do art. 13 da Instrução $\mathrm{CVM} \mathrm{n}^{\circ} 358$, à pena de multa no valor de $\mathrm{R} \$ 596.600,00$, correspondente a duas vezes o montante do lucro potencial obtido na operação.
} 
relatório, consistia em manter uma carteira de ações diversificada, composta por ações de cinco companhias, tendo como foco o longo prazo, na medida em que vinha carregando a mesma carteira por pelo menos dez meses. Ao negociar no dia 19.1.2009, Frederico Lima concentrou todas as suas aplicações em ações ordinárias da Aracruz, e, a despeito do perfil apresentado anteriormente, vendeu toda sua nova posição apenas dois dias depois.

Não há sombra de dúvidas de que os atos praticados por Frederico Lima não se assemelham com a atuação de um investidor que decide apostar num mero boato de mercado, em que há uma chance possível, porém, incerta de retorno, pois, ao decidir, inopinadamente, alterar completamente todos seus investimentos em ações para investir numa única companhia, ele demonstra a certeza daquele que tem conhecimento da iminente reestruturação e de seus efeitos positivos para as ações ordinárias da Aracruz $^{134}$.

Por outro lado, caso o investidor tenha negociado com diversos valores mobiliários no período que antecedeu a divulgação da informação privilegiada de determinada companhia, é menor a probabilidade de que este estivesse negociando na posse de tal informação. Pela lógica do homem racional, o investidor deveria concentrar a maior quantidade possível de recursos no valor mobiliário afetado pela informação privilegiada, de forma a potencializar seu lucro em um investimento garantido.

Inclusive, conforme esclarece a Diretora Luciana Dias, no âmbito do PAS CVM n ${ }^{\circ} 11 / 08^{135}$, a ausência de concentração de recursos em transações com o valor mobiliário afetado pela informação privilegiada é um contra indício da prática de insider trading (destacou-se):

No entanto, conjuntamente à sua primeira aquisição de ações da Suzano, que somava cerca de $\mathrm{R} \$ 100 \mathrm{mil}$, o Sr. Jorge Rzezinski adquiriu $\mathrm{R} \$ 778 \mathrm{mil}$ em outros ativos, por meio da Corretora Prosper, conforme nota de corretagem $n^{\circ} 15043$ (fls. 1140/1161). Esses números demonstram que os seus investimentos não foram especialmente canalizados para as ações da Suzano. E, conforme anteriormente discutido, a falta de canalização dos investimentos para o ativo é

${ }^{134}$ Extrato da Sessão de Julgamento do Processo Administrativo Sancionador CVM no 25/2010. Diretor-Relator: Henrique Balduino Machado Moreira. Presidente da sessão de julgamento: Leonardo P. Gomes Pereira. Data de Julgamento: 04.07.2017. Disponível em: 〈http://www.cvm.gov.br/export/sites/cvm/sancionadores/sancionador/anexos/2017/25_2010.pdf $>$. Acesso em: 10.10.2017.

135 No PAS CVM n ${ }^{\circ} 11 / 08$, todos os acusados foram absolvidos pela imputação de utilização indevida de informação privilegiada na negociação de valores mobiliários de emissão da Suzano, em descumprimento ao $\S 4^{\circ}$ do art. 155 da Lei $n^{\circ} 6404 / 76$. 
um forte contra-indício de que informações privilegiadas eram detidas pelo $\underline{\text { Acusado }}^{136}$

Além disso, outra conduta também considerada um contra indício em casos semelhantes é a compra ou venda continuada do valor mobiliário afetado pela informação privilegiada mesmo após a divulgação da mesma pois, se o que levou o investidor a negociar com determinado valor mobiliário foi a posse da informação privilegiada, com sua divulgação, não haveria mais motivo para continuar comprando ou vendendo.

No PAS CVM no SP2013/12137, a Diretora Luciana Dias entendeu que a intenção de auferir vantagem não foi configurada pela apresentação de justificativa das transações e continuidade das aquisições de valores mobiliários após a divulgação do fato relevante (com grifos):

Primeiro, com base nos documentos acostados aos autos por João Queiroz, não me parece haver dúvidas - nem mesmo por parte da Acusação - de que a operação de Financiamento descrita pelos dois defendentes realmente ocorreu. No âmbito daquela operação, a concessão de crédito a João Queiroz teve como contrapartida o empréstimo de ações de emissão da Hypermarcas em garantia ao Credit Suisse. Assim, parece-me clara a existência de motivos para que João Queiroz adquirisse ações de emissão da Companhia previamente à celebração dos contratos com o banco em 30.3.2012.

Segundo, é relevante o fato de que as aquisições feitas em bolsa por João Queiroz não se limitaram ao período destacado pela Acusação. Como demonstrado nos autos, aquele acusado continuou a adquirir ações de emissão da Hypermarcas até 30.3.2012, seguindo o mesmo padrão de comportamento independentemente da existência de informações privilegiadas ${ }^{138}$.

136 Extrato da Sessão de Julgamento do Processo Administrativo Sancionador CVM no 11/08. Diretora-Relatora: Luciana Dias. Presidente Interino da sessão de julgamento: Otavio yazbek. Data de Julgamento: 21.08.2012. Disponível em: <http://www.cvm.gov.br/export/sites/cvm/sancionadores/sancionador/anexos/2012/20120821_PA S_1108.pdf>. Acesso em: 10.10.2017.

${ }^{137}$ No PAS CVM n ${ }^{\circ}$ SP2013/12, o acusado João Alves de Queiroz Filho foi absolvido da imputação de utilização indevida de informação privilegiada na negociação de valores mobiliários de emissão da Hypermarcas S.A., em descumprimento ao art. 155, $\S 1^{\circ}$, da Lei $\mathrm{n}^{\circ} 6.404$, combinado com o art. 13 da Instrução CVM n 358.

${ }^{138}$ Extrato da Sessão de Julgamento do Processo Administrativo Sancionador CVM n ${ }^{\circ}$ SP2013/12. Diretora-Relatora: Luciana Dias. Presidente da sessão de julgamento: Leonardo P. Gomes Pereira. Data de Julgamento: 18.08.2015. Disponível em: <http://www.cvm.gov.br/export/sites/cvm/sancionadores/sancionador/anexos/2015/20150818_PA S_SP201312.pdf>. Acesso em: 10.10.2017 
Já no PAS CVM no RJ 2012/9808 ${ }^{139}$, um dos acusados além de não concentrar seus recursos disponíveis na compra do valor mobiliário afetado pela informação privilegiada, ainda continuou comprando mesmo após a divulgação de tal informação, da qual supostamente teve conhecimento privilegiado (com grifos):

As negociações de ações realizadas pelo Acusado no período suspeito e posteriormente à divulgação do Fato Relevante, em 16.02.12, revelam que ele adquiriu $75 \%$ de sua posição em Sanepar depois da divulgação do referido Fato. Apurou-se que no dia 09 de fevereiro ele adquiriu 2.400 ações pelo valor de R\$ $13.558,88$, e nos dias 28 e 29 de fevereiro; 12 e 13 de março, e 08 de maio, ele adquiriu o total de 5.600 ações, nas quais investiu o valor de $\mathrm{R} \$ 39.450,00$.

Destaco, ainda, que o Acusado, no dia 09 de fevereiro, quando comprou 2.400 ações da Sanepar por R $\$ 13.558,00$, também vendeu 5.400 ações de emissão da Redentor Energia S.A. (código ISIN RDTR3) por R $\$ 36.994,00$, o que demonstra que ele não reinvestiu a totalidade dos recursos obtidos com a venda, e ao assim agir deixou de adquirir uma quantidade maior de ações da Sanepar.

O Acusado lembra, ademais, que possuía conta margem na Corretora Ágora em razão de sua carteira de ações, o que lhe proporcionava $\mathrm{R} \$ 500$ mil de crédito automático para investir. Acrescenta que o investimento de $\mathrm{R} \$ 13,5$ mil em ações da Sanepar realizado antes do Fato Relevante representava apenas 0,4\% do seu patrimônio total aplicado em ações, fundos de investimento em ações e títulos públicos (fls. 1.504 e 1.505).

Naquele momento, o Acusado poderia ter concentrado seus investimentos nas ações de Sanepar e com isso obter lucro maior, aproveitando-se da valorização das ações que provavelmente ocorreria após a divulgação do Fato Relevante, mas assim não procedeu. E, contrariamente à conduta esperada de um insider trading, adquiriu 2,3 vezes mais ações da Sanepar após a divulgação do Fato Relevante quando a cotação já havia sido impactada positivamente pela notícia, e se valorizou em $6,8 \%$ do que havia adquirido anteriormente ${ }^{140}$.

Também existem outras condutas contraditórias consideradas pela Comissão de Valores Mobiliários como contra indícios do uso indevido de informação privilegiada. Nesse sentido, a lógica é a seguinte, partindo-se do pressuposto de que o investidor está na posse de informação privilegiada, certas condutas não fazem sentido, pois, por exemplo, aumentam o risco da

\footnotetext{
${ }^{139}$ No PAS CVM nº RJ2012/9808, o acusado João José de Araújo Pereira Pavel foi absolvido da imputação de uso de informação privilegiada ao negociar ações preferenciais da SANEPAR, em suposta infração ao art. $155, \S 4^{\circ}$, da Lei $n^{\circ} 6.404$, combinado com o $\$ 1^{\circ}$, art. 13 , da Instrução CVM $n^{\circ} 358$.

140 Extrato da Sessão de Julgamento do Processo Administrativo Sancionador CVM $\mathrm{n}^{\circ}$ RJ2012/9808. Diretor-Relator: Roberto Tadeu Antunes Fernandes. Presidente da sessão de julgamento: Leonardo P. Gomes Pereira. Data de Julgamento: 18.12.2015. Disponível em: <http://www.cvm.gov.br/export/sites/cvm/sancionadores/sancionador/anexos/2015/20151218_PA S_RJ20129808.pdf $>$. Acesso em: 10.10.2017.
} 
operação - essas condutas são entendidas como contra indícios da prática de insider trading.

No PAS CVM n ${ }^{\circ} 02 / 2010^{141}$, os investidores são acusados de vender valores mobiliários antes da divulgação de fato relevante de forma a evitar prejuízo. No entanto, ficou comprovado que durante o período que antecedeu a divulgação da informação, um dos acusados comprou mais ações do que vendeu, aumentando potencialmente seu prejuízo - e, com isso, o Diretor Roberto Tadeu Fernandes entendeu descaracterizado o elemento essencial da intenção de obter vantagem (destacou-se):

A lógica da acusação imputada aos Acusados é de que eles venderam as ações de posse de informação relevante não divulgada, sabedores de que, ao tornar pública a operação de reorganização societária da Cosan, o valor das ações cairia. Com isso, conclui a acusação, a Aguassanta evitou perdas de $\mathrm{R} \$ 3.562 .657,00$ e a Rio das Pedras de R $\$ 611.064,00$, ao negociarem antes da data de divulgação do Fato Relevante, quando a ação encerrou o dia cotada a $\mathrm{R} \$ 34,63$.

Eu não faria reparos à conclusão da acusação, me alinharia a ela integralmente, se a Aguassanta não tivesse adquirido 500.000 ações concomitante às vendas que realizava, também de posse das informações ainda não divulgadas ao mercado. Efetivada a compra, e pouco importam os motivos que levaram à sua realização, constato que a Aguassanta, no que vou denominar de "período vedado para negociação" estabelecido pela acusação, comprou mais ações do que vendeu, passando a deter mais 56.900 ações da Cosan do que tinha antes de 18.04 (data inicial do período).

Porém, se a lógica que permeou a acusação é de que a Aguassanta vendeu ações naquele momento para evitar prejuízos em que incorreria caso vendesse após a divulgação da informação relevante, diante da certeza que tinha na queda do valor das ações, não faria nenhum sentido ela também adquirir ações no mesmo momento, e muito menos ainda adquirir uma quantidade maior do que ela vendeu. Ao assim agir, ela aumentou o seu potencial prejuízo, ao invés de diminuí-lo. Tal postura, de compradora e não de vendedora, a meu ver, desmonta a tese da acusação de que a Aguassanta pretendia obter vantagens com as vendas das ações de posse de informação ainda não revelada ao mercado ${ }^{142}$.

\footnotetext{
${ }^{141}$ No PAS CVM nº 02/2010, os acusados Aguassanta Participações S.A. e Rubens Ometto Silveira Mello foram absolvidos da imputação de negociação de ações da Cosan antes da divulgação ao mercado do fato relevante sobre o plano de reorganização societário do Grupo Cosan, em suposta infração ao disposto no artigo 13, caput, da Instrução CVM n³58.

${ }^{142}$ Extrato da Sessão de Julgamento do Processo Administrativo Sancionador CVM no 02/2010. Diretor-Relator: Roberto Tadeu Antunes Fernandes. Presidente da sessão de julgamento: Leonardo P. Gomes Pereira. Data de Julgamento: 09.07.2013. Disponível em: <http://www.cvm.gov.br/export/sites/cvm/sancionadores/sancionador/anexos/2013/20130709_PA S_022010.pdf>. Acesso em: 10.10.2017.
} 
Um indício clássico da prática de insider trading é a negociação a termo - principalmente, quando essa espécie de transação não faz parte do perfil de negociação do acusado. $\mathrm{Na}$ operação a termo o investidor não precisa ter recursos disponíveis no momento da negociação, pois o pagamento é fixado para um momento futuro.

Normalmente, o investidor na posse de informação privilegiada tem urgência para negociar com determinado valor mobiliário, pois a partir do momento em que tal informação for divulgada, este perde a sua vantagem em relação ao mercado. Assim, uma solução para o investidor sem recursos suficientes na posse de informação privilegiada é a operação a termo - até porque como a vantagem é quase certa, o risco da operação é mais baixo do que em outras transações. Nas palavras da Diretora Luciana Dias no âmbito do PAS CVM n ${ }^{\circ}$ RJ2013/2714 ${ }^{143}$ (destacou-se):

Adicionalmente, entendo que o fato de o Acusado ter negociado as ações da Contax a termo é outro indício de que ele tinha urgência na aquisição e, por isso, corrobora as evidências de que detinha informações privilegiadas.

Como já me manifestei em outros casos, as operações de compra a termo são absolutamente legítimas e imprescindíveis para uma série de estratégias de investimento no mercado de valores mobiliários. Elas denotam, no entanto, que um investidor aposta numa alta daquele ativo no curto prazo e, apesar de não ter recursos suficientes ou não querer disponibilizá-los naquele momento, deseja travar o preço de compra. Por isso, compra referido ativo a termo, fixando o valor de aquisição no preço de mercado daquele momento, mais uma taxa de juros livremente estabelecida. Essa operação, em geral, indica que o investidor aposta que a valorização daquele ativo no curto prazo será superior à taxa de juros praticada no mercado.

Foi exatamente o que o Acusado fez. $\mathrm{O}$ fato de a compra ter sido feita a termo indica que ele, apesar de não dispor dos recursos necessários, conforme admitido na conversa telefônica com R.R., apontava em uma alta deste ativo num espaço relativamente curto de tempo e desejava travar o valor de aquisição, provavelmente, para antes do anúncio da compra da Ability pela Contax ${ }^{144}$.

143 No PAS CVM nº RJ2013/2714, o acusado Guilherme Colonna Rosman foi condenado, pela negociação de ações de emissão da Contax Participações S.A. com uso indevido de informação relevante ainda não divulgada ao mercado, em infração ao art. $155, \S^{\circ}$, da Lei $n^{\circ} 6.404$, bem como ao art. $13, \S 1^{\circ}$, da Instrução CVM n ${ }^{\circ} 358$, à pena de multa no valor de $\mathrm{R} \$ 200.000,00$.

144 Extrato da Sessão de Julgamento do Processo Administrativo Sancionador CVM $\mathrm{n}^{\circ}$ RJ2013/2714. Diretora-Relatora: Luciana Dias. Presidente da sessão de julgamento: Leonardo P. Gomes Pereira. Data de Julgamento: 07.10.2014. Disponível em: <http://www.cvm.gov.br/export/sites/cvm/sancionadores/sancionador/anexos/2014/20141007_PA S_RJ20132714.pdf>. Acesso em: 10.10.2017. 
Outro indício do uso indevido de informação privilegiada na negociação de valores mobiliários, comum a prática de todos os crimes, é a contradição em depoimentos. Nesse sentido, o acusado, mais de uma vez questionado pela mesma conduta (no caso, uma transação suspeita) acaba por apresentar mais de uma versão para os mesmos fatos.

Ora, pela lógica é mais provável que alguém que esteja mentindo ou tenha algo a esconder acabe por se contradizer em suas manifestações. Até porque, em princípio, a verdade é uma só. Nesse sentido, a Comissão de Valores Mobiliários utiliza as incongruências presentes nos depoimentos dos acusados como indício da prática de insider trading.

No PAS CVM n ${ }^{\circ} 25 / 2010^{145}$, dois acusados, que possuíam vínculo profissional e pessoal comprovado, modificaram a versão dos fatos entre o primeiro questionamento formulado pela Comissão de Valores Mobiliários e o depoimento pessoal de cada um. Esse indício foi considerado pelo Colegiado para justificar a condenação dos acusados (com grifos):

A Acusação também aponta que, ao ser inicialmente questionado, Marco Bernardi afirmou não se recordar da razão pela qual teria decidido comprar ações ordinárias da Aracruz, nem ter recebido qualquer recomendação a respeito, porém, em depoimento pessoal prestado posteriormente apresentou outra versão. Nesta oportunidade, declarou que, em razão de um "papo de padaria" com amigos, onde teria sido mencionado um release de uma instituição financeira, decidiu realizar a operação, pois percebeu uma oportunidade de obter ganhos, embora não soubesse explicar as diferenças entre uma ação ordinária e ação preferencial, tampouco por que a reestruturação da Aracruz beneficiou mais a ação ordinária do que a ação preferencial da Companhia (fls. 916 e 917).

Em contato preliminar da SPS, Fernando Nascimento também não soube explicar a motivação da negociação, tendo declarado que: "pelo que eu me lembro, é, é, notícia de, de jornal, que, que, pelo que me lembro, que a Aracruz ia ser comprada ou vendida, não sei." Posteriormente, em depoimento pessoal, Fernando Nascimento também alterou sua versão inicial para afirmar que comprou ações ordinárias da Aracruz em função de uma conversa com amigos em um "happy

\footnotetext{
145 No PAS CMV no 25/2010, os acusados Marco Antonio Bernardi e Fernando Sérgio Rocha Nascimento foram condenados, pelo uso de informação privilegiada na negociação de ações ordinárias da Aracruz Celulose S.A., em infração ao disposto no art. 155, § $4^{\circ}$, da Lei $n^{\circ} 6.404$, combinado com o $\S 1^{\circ}$ do art. 13 da Instrução CVM n ${ }^{\circ} 358$, a pena de multa, respectivamente, no valor de $\mathrm{R} \$ 122.959,50$, correspondente a uma vez e meia o montante do lucro obtido na operação, e R\$97.299,00, correspondente a uma vez e meia o montante do lucro obtido na operação.
} 
hour", e que decidiu investir, aleatoriamente, nas ações ordinárias da Aracruz (fls. 918 e 919$)$.

(...)

Em que pese os argumentos apresentados em defesa, a total atipicidade das negociações, o timing perfeito da negociação e as contradições das manifestações apresentadas por Marco Bernardi e Fernando Nascimento são indícios fortes, consistentes e convergentes que levam a segura conclusão de que eles negociaram ações ordinárias da Aracruz sabedores do momento da divulgação da reestruturação e do benefício que ela acarretaria às ações ordinárias da Companhia $^{146}$.

Por último, mas não menos importante, analisaremos a apresentação de justificativa da negociação com valores mobiliários como contra indício da utilização de informação privilegiada na negociação de valores mobiliários.

Bom, como se sabe, para a configuração da prática de insider trading é necessário o uso indevido da informação privilegiada com o intuito de obter vantagem indevida. Ora, mas e se a transação possui outra justificativa que não a posse da informação privilegiada?

É obvio que a justificativa apresentada pelo acusado precisa ser cuidadosamente analisada, pois não basta que o investigado apresente uma destinação da vantagem obtida com a realização da transação para que se esteja diante de um contra indício. Por exemplo, no PAS CVM n ${ }^{\circ}$ RJ2012/7880 ${ }^{147}$, o Diretor Roberto Tadeu Antunes esclareceu que a motivação apresentada pelo acusado representa apenas a destinação dos recursos provenientes da transação, não sendo capaz de descaracterizar a

\footnotetext{
${ }^{146}$ Extrato da Sessão de Julgamento do Processo Administrativo Sancionador CVM no 25/2010. Diretor-Relator: Henrique Balduino Machado Moreira. Presidente da sessão de julgamento: Leonardo P. Gomes Pereira. Data de Julgamento: 04.07.2017. Disponível em: $\langle\underline{\mathrm{http}} / / / \mathrm{www} . \mathrm{cvm}$. gov.br/export/sites/cvm/sancionadores/sancionador/anexos/2017/25_2010.pdf $>$. Acesso em: 10.10.2017.

${ }^{147}$ No PAS CVM no RJ2012/7880, o acusado (Rafael Palladino) foi condenado, por ter negociado com ações de emissão do Banco Panamericano S.A., com o uso da empresa Max Control Assessoria e Investimento Ltda., da qual era proprietário, nos dias 24 e 28.09 .10 e 07.10 .10 , antes da publicação do Fato Relevante em 09.11.10, em infração ao artigo 13, caput, da Instrução CVM no 358, combinado com o $\S 1^{\circ}$ do artigo 155 da Lei ${ }^{\circ} 6.404$, à pena de multa no valor de $877.200,00$, correspondente ao triplo da perda evitada, na forma do inciso II do artigo 11 da Lei $\mathrm{n}^{\mathrm{o}} 6.385$, combinado com o inciso III do $\S 1^{\circ}$ do mesmo artigo.
} 
prática de insider trading, que se aperfeiçoou no momento da venda dos valores mobiliários (destacou-se):

Por fim, e na derradeira tentativa de eximir-se de responsabilidade, Rafael Palladino alega que a motivação para as vendas das ações foi a necessidade de aportar recursos nas obras que estavam sendo realizadas pela empresa Max America Negócios Imobiliários Ltda., também de sua propriedade, como confirmariam as notas fiscais e recibos de pagamentos anexados às fls. 238/262. Mesmo admitindo que este tenha sido o destino dos recursos provenientes das vendas das ações, tal fato não abala a minha convicção de que Rafael Palladino negociou com o uso de informações relevantes ainda não divulgadas ao mercado, pois o uso que ele fez dos recursos, qualquer que fosse ele, não tem o condão de descaracterizar a irregularidade cometida, afinal, o insider trading se concretizou no momento em que ele vendeu as suas ações, escapando da desvalorização que se avizinhava $^{148}$.

Já no PAS CVM nº RJ2014/3225 ${ }^{149}$, o mesmo Diretor, apesar de afirmar que a apresentação da justificativa por si só não é capaz de afastar a condenação, no caso concreto, considerou a apresentação de justificativa econômico-financeira para fundamentar a absolvição da acusada (com grifos):

Ademais, a Acusada trouxe justificativa econômico-financeira para a sua decisão de alienar as ações da HRT naquele momento.

Alega, por exemplo, que estava diante de uma série de compromissos financeiros já assumidos e que precisavam ser honrados, sobretudo após sua saída da administração da HRT em maio de 2013, entre eles os relativos ao casamento de seu filho, realizado em setembro de 2013, fato que revelou ainda na fase investigativa deste processo (fls. 62; fls. 171 a 217).

Argui, também, que havia adquirido dois imóveis em Brasília, ainda na planta, que exigiam o pagamento de parcelas intermediárias de valores significativos nos anos de 2013 e 2014, aquisições que obrigaram a Acusada a renegociar o contrato com uma das construtoras, como se infere dos documentos apensos às fls. $179 \mathrm{e}$ 185, renegociação esta que reforça a necessidade de obtenção de recursos por parte da Acusada.

Não quero com isso afirmar que a existência de uma justificativa econômicofinanceira para a negociação das ações possa, por si só, afastar uma condenação de insider trading. Entendo, contudo, que a existência deste contraindício no

148 Extrato da Sessão de Julgamento do Processo Administrativo Sancionador CVM $\mathrm{n}^{\circ}$ RJ2012/7880. Diretor-Relator: Roberto Tadeu Antunes Fernandes. Presidente da sessão de julgamento: Leonardo P. Gomes Pereira. Data de Julgamento: 13.11.2013. Disponível em: <http://www.cvm.gov.br/export/sites/cvm/sancionadores/sancionador/anexos/2013/20131119_PA S RJ20127880.pdf >. Acesso em: 10.10.2017.

${ }^{149}$ No PAS CVM no RJ2014/3225, a acusada Maria Emília Rocha Mello de Azevedo foi absolvida da imputação de utilização indevida de informação privilegiada na negociação de valores mobiliários de emissão da HRT, por infração ao art. $155, \S 4^{\circ}$, da Lei $n^{\circ} 6.404$, c/c o $\S 1^{\circ}$ do art. 13 da Instrução CVM no 358. 
presente caso, adicionado ao fato da inexistência de provas, ou mesmo de indícios sérios e convergentes, é suficiente, a meu juízo, para admitir que as negociações da Acusada não foram motivadas pelo uso de informação relevante ainda não divulgada ao mercado ${ }^{150}$.

Bom, finalizada a análise do presente Capítulo, foi possível demonstrar o atual entendimento da Comissão de Valores Mobiliários em relação aos indícios e contra indícios usualmente utilizados pelo Colegiado para justificar a condenação e absolvição dos acusados pela prática de insider trading.

É fato que a análise dos indícios e contra indícios constante do presente não é capaz esgotar o tema, primeiro, porque em cada Processo Sancionador podemos encontrar indícios e contra indícios incomuns apresentados pela acusação ou pela defesa.

Além disso, mesmo existindo certos entendimentos consolidados da Comissão de Valores Mobiliários, os indícios e contra indícios devem ser analisados vis-à-vis ao caso concreto.

Enfim, diante de um Processo Sancionador é necessário atentar para a presença das condutas e caraterísticas descritas no presente Capítulo, pois elas serão levadas em consideração para a formação do convencimento dos membros do Colegiado da Comissão de Valores Mobiliários e, consequentemente, para a fundamentação da decisão.

150 Extrato da Sessão de Julgamento do Processo Administrativo Sancionador CVM $\mathrm{n}^{\circ}$ RJ2014/3225. Diretor-Relator: Roberto Tadeu Antunes Fernandes. Presidente da sessão de julgamento: Leonardo P. Gomes Pereira. Data de Julgamento: 13.09.2016. Disponível em: <http://www.cvm.gov.br/export/sites/cvm/sancionadores/sancionador/anexos/2016/20160913_PA S_RJ20143225.pdf>. Acesso em: 10.10.2017 


\section{CONCLUSÃO}

Por todo o exposto no presente trabalho, não há dúvidas sobre a importância da apuração e responsabilização pelo uso indevido de informação privilegiada, inclusive, por ser o crime mais grave que pode ocorrer no âmbito do mercado de capitais. Ainda mais no contexto atual de combate a impunidade das classes elitistas na sociedade brasileira.

Além disso, é possível concluir que, por um lado, a prova indiciária é um meio válido fundamentar as decisões do Colegiado da Comissão de Valores Mobiliários no julgamento de Processos Sancionadores, assim como qualquer outro meio de prova legalmente previsto ou permitido.

Por outro lado, devemos ficar atentos, pois, como a prova indiciária é uma prova de probabilidade, é necessário analisar, no caso concreto, se foram apresentados indícios múltiplos, veementes e convergentes - capazes de justificar a condenação.

A investigação realizada pela Comissão de Valores Mobiliários na apuração de responsabilidade pela prática de insider trading, principalmente quando se trata de insider secundário, se concentra na análise de indícios da referida prática.

Para tanto, são analisados, dentre outros aspectos do caso concretro (i) timing das transações suspeitas, (ii) relações pessoais do investigado (iii) perfil de negociação do acusado, (iv) habitualidade e mudança de comportamento do investigado, (v) concentração de investimento em determinado valor mobiliário, (vi) operações a termo.

Ademais, foi possível constatar através do exame de Processos Sancionadores, que apuram a responsabilidade pelo uso indevido de informação privilegiada, que a mesma lógica é aplicada a maioria dos indícios explorados no âmbito de Processo Sancionador. 
Nesse sentido, todo aspecto da transação investigada é analisado do ponto de vista do investidor racional. Todos os aspectos da conduta que não fazem sentido do ponto de vista do investidor racional e só se justifica pela negociação com informação privilegiada, constituem indícios da prática insider trading. Agora, todos os elementos que fazem sentido do ponto de vista do investidor racional, constituem contra indícios da referida prática.

Ainda assim, não foi possível constatar um padrão das decisões do Colegiado da Comissão de Valores Mobiliários no âmbito dos referidos Processos Sancionadores, no sentido de que havendo a presença de certos indícios, o acusado sempre será condenado ou havendo a presença de certos contra indícios, o acusado sempre será absolvido.

É claro que o estudo da prova indiciária através da análise de precedentes da Comissão de Valores Mobiliários pode ser utilizado como um guia para o exame dos indícios e contra indícios do caso concreto, mas cada Processo Sancionador é único e com peculiaridades que demandam a atenção de cada um dos membros do Colegiado na formação de sua decisão.

A verdade é nada pode substituir a análise de um caso concreto sendo necessário analisar os indícios e contra indícios um a um, tendo sempre em vista as particularidades do caso, para depois, decidir com base no resultado do exame desse conjunto de indícios e contra indícios. 


\section{BIBLIOGRAFIA}

ASSIS MOURA, Maria Thereza Rocha de. A Prova por indícios no Processo Penal. São Paulo: Saraiva, 1994.

BARBOSA, Marcelo. Algumas notas sobre insider trading. IN: VENANCIO FILHO, Alberto; LOBO, Carlos Augusto Silveira; ROSMAN, Luiza Alberto Colonna. LEI das S.A. em seus 40 anos. Rio de Janeiro: Forense, 2017.

BRASIL. Constituição da República Federativa do Brasil de 1988. Disponível em: <http://www.planalto.gov.br/ccivil_03/constituicao/constituicaocompilado. $\underline{\mathrm{htm}}>$.

BRASIL. Decreto-Lei no 3.689, de 3 de outubro de 1941. Disponível em: <http://www.planalto.gov.br/ccivil_03/decreto-lei/Del3689.htm>.

BRASIL. Lei $\mathrm{n}^{\mathrm{o}}$ 4.728, de 14 de julho de 1965. Disponível em: <http://www.planalto.gov.br/ccivil_03/leis/L4728.htm>.

BRASIL. Lei $\mathrm{n}^{\circ}$ 6.385, de 07 de dezembro de 1976. Disponível em: <https://www.planalto.gov.br/ccivil_03/leis/L6385.htm>.

BRASIL. Lei $\mathrm{n}^{\circ}$ 6.404, de 15 de dezembro de 1976. Disponível em: <http://www.planalto.gov.br/ccivil_03/leis/L6404consol.htm>.

BRASIL. Supremo Tribunal Federal (STF). Ação Penal: 470 Minas Gerais, Relator: Ministro Roberto Barroso. Data de Julgamento: 10.02.2015. Data de Publicação: DJe-032 Divulgação: 18.02.2015; Publicação: 19/02/2015.

BRASIL. Supremo Tribunal Federal (STF). Habeas Corpus no 113.118/SP., Relator: Ministro Luiz Fux. Data de Julgamento: 20.03.2012. Primeira Turma. Data de Publicação: DJe-081 Divulgação: 25.04.2012; Publicação: 26/04/2012. DJe-081. 
BRASIL. Supremo Tribunal Federal (STF). Habeas Corpus $n^{\circ}$ 70344/RJ. Relator: Ministro Paulo Brossard. Data de Julgamento: 14.09.1993. Segunda Turma. Data de Publicação: DJ 22-10-1993.

CAMPOS, Luiz Antonio de Sampaio. Deveres e Responsabilidades. IN: LAMY FILHO, Alfredo; PEDREIRA, José Bulhões. Direito das companhias. $2^{\text {a }}$ edição. Rio de Janeiro: Forense, 2017.

CARRARA, Francesco. Programa do curso de direito criminal. Volume 1. Campinas: LZN, 2002.

CARVALHOSA, Modesto. Comentários à lei de sociedades anônimas. Volume 3. $6^{\text {a }}$ edição. São Paulo: Saraiva, 2014.

COMISSÃO DE VALORES MOBILIÁRIOS. Instrução CVM nº 358, de 3 de janeiro de 2002. Disponível em: Disponível em: $<$ http://www.cvm.gov.br/legislacao/instrucoes/inst358.html〉.

EIZIRIK, Nelson. A lei das S/A Comentada. Volume III. 2a edição. São Paulo: Quartier Latin, 2015.

EIZIRIK, Nelson; GAAL, Ariádna B.; PARENTE, Flávia; HENRIQUES, Marcus de Freitas. Mercado de capitais - regime jurídico. $3^{\text {a }}$ edição. Rio de Janeiro: Renovar, 2011.

Extrato da Sessão de Julgamento do Processo Administrativo Sancionador CVM n ${ }^{\circ}$ 02/2010. Diretor-Relator: Roberto Tadeu Antunes Fernandes. Presidente da sessão de julgamento: Leonardo P. Gomes Pereira. Data de Julgamento: $\quad$ 09.07.2013. Disponível em: <http://www.cvm.gov.br/export/sites/cvm/sancionadores/sancionador/anex os/2013/20130709_PAS_022010.pdf>.

Extrato da Sessão de Julgamento do Processo Administrativo Sancionador CVM n ${ }^{\circ}$ 04/04. Diretor-Relator e Presidente da sessão de julgamento: Marcelo Fernandez Trindade. Data de Julgamento: 28.06.2006. Disponível 
em:

<http://www.cvm.gov.br/export/sites/cvm/sancionadores/sancionador/anex os/2006/20060628_PAS_0404.pdf>.

Extrato da Sessão de Julgamento do Processo Administrativo Sancionador CVM no 06/2003. Diretor-Relator: Norma Jonssen Parente. Presidente da sessão de julgamento: Marcelo Fernandez Trindade. Data de Julgamento: 14.09.2005. Disponível em: <http://www.cvm.gov.br/export/sites/cvm/sancionadores/sancionador/anex os/2005/20050914_PAS_CVM0603.pdf>.

Extrato da Sessão de Julgamento do Processo Administrativo Sancionador CVM n ${ }^{\circ}$ 06/95. Diretora-Relatora: Norma Jonssen Parente. Presidente da sessão de julgamento: Marcelo Fernandez Trindade. Data de Julgamento: 05.05.2005. Disponível em: <http://www.cvm.gov.br/sancionadores/sancionador/anexos/2005/2005050 5_PAS_0695.pdf $>$.

Extrato da Sessão de Julgamento do Processo Administrativo Sancionador CVM no 09/04. Diretor-Relator: Pedro Oliva Marcilio de Sousa. Presidente da sessão de julgamento: Marcelo Fernandez Trindade. Data de Julgamento: 20.06.2006. Disponível em: <http://www.cvm.gov.br/export/sites/cvm/sancionadores/sancionador/anex os/2006/20060620_PAS 0904.pdf>.

Extrato da Sessão de Julgamento do Processo Administrativo Sancionador CVM no 11/08. Diretora-Relatora: Luciana Dias. Presidente Interino da sessão de julgamento: Otavio yazbek. Data de Julgamento: 21.08.2012. Disponível em: <http://www.cvm.gov.br/export/sites/cvm/sancionadores/sancionador/anex os/2012/20120821_PAS_1108.pdf>. 
Extrato da Sessão de Julgamento do Processo Administrativo Sancionador CVM no 11/09. Diretor-Relator: Luciana Dias. Presidente da sessão de julgamento: Maria Helena dos Santos Fernandes de Santana. Data de Julgamento: 03.04.2012. Disponível em: <http://www.cvm.gov.br/export/sites/cvm/sancionadores/sancionador/anex os/2012/20120403_PAS 1109.pdf>.

Extrato da Sessão de Julgamento do Processo Administrativo Sancionador CVM no 13/09. Diretor-Relator: Eli Loria. Presidente da sessão de julgamento: Maria Helena dos Santos Fernandes de Santana. Data de Julgamento: 13.12.2011. Disponível em: <http://www.cvm.gov.br/export/sites/cvm/sancionadores/sancionador/anex os/2011/20111213 PAS 1309.pdf>.

Extrato da Sessão de Julgamento do Processo Administrativo Sancionador CVM n ${ }^{\circ}$ 13/2000. Diretor-Relator: Marcelo Fernandes Trindade. Presidente da sessão de julgamento: Norma Jonssen Parente. Data de Julgamento: 17.04.2002. Disponível em: <http://www.cvm.gov.br/export/sites/cvm/sancionadores/sancionador/anex os/2002/20020417_PAS_1300.pdf>.

Extrato da Sessão de Julgamento do Processo Administrativo Sancionador CVM n ${ }^{\circ}$ 15/2010. Diretor-Relator: Roberto Tadeu Antunes Fernandes. Presidente da sessão de julgamento: Leonardo P. Gomes Pereira. Data de Julgamento: 08.12.2015. Disponível em: <http://www.cvm.gov.br/export/sites/cvm/sancionadores/sancionador/anex os/2015/20151208_PAS_152010.pdf>.

Extrato da Sessão de Julgamento do Processo Administrativo Sancionador CVM no 22/94. Diretor-Relator: Luiz Antonio de Sampaio Campos. Presidente da sessão de julgamento: Luiz Leonardo Cantidiano. Data de Julgamento: 15.04.2004. Disponível em: 
$<$ http://www.cvm.gov.br/export/sites/cvm/sancionadores/sancionador/anex os/2004/20040415 PAS 2294.pdf>.

Extrato da Sessão de Julgamento do Processo Administrativo Sancionador CVM n ${ }^{\circ}$ 23/10. Diretor-Relator: Roberto Tadeu Antunes Fernandes. Presidente da sessão de julgamento: Leonardo P. Gomes Pereira. Data de Julgamento: 04.11.2014. Disponível em: <http://www.cvm.gov.br/export/sites/cvm/sancionadores/sancionador/anex os/2014/20141104_PAS_232010.pdf>.

Extrato da Sessão de Julgamento do Processo Administrativo Sancionador CVM no 24/05. Diretor-Relator: Sergio Weguelin. Presidente da sessão de julgamento: Maria Helena dos Santos Fernandes de Santana. Data de Julgamento: $\quad$ 07.10.2008. Disponível em: <http://www.cvm.gov.br/export/sites/cvm/sancionadores/sancionador/anex os/2008/20081007_PAS_2405.pdf>.

Extrato da Sessão de Julgamento do Processo Administrativo Sancionador CVM no 25/2010. Diretor-Relator: Henrique Balduino Machado Moreira. Presidente da sessão de julgamento: Leonardo P. Gomes Pereira. Data de Julgamento: 04.07.2017. Disponível em: <http://www.cvm.gov.br/export/sites/cvm/sancionadores/sancionador/anex os/2017/25 2010.pdf>.

Extrato da Sessão de Julgamento do Processo Administrativo Sancionador $\mathrm{CVM} \mathrm{n}^{\circ} \mathrm{RJ} 2006 / 5928$. Diretor-Relator e Presidente da sessão de julgamento: Pedro Oliva Marcilio de Sousa. Data de Julgamento: 17.04.2007. Disponível em:

<http://www.cvm.gov.br/export/sites/cvm/sancionadores/sancionador/anex os/2007/20070417_PAS_RJ20065928.pdf>.

Extrato da Sessão de Julgamento do Processo Administrativo Sancionador CVM nº RJ2011/3823. Diretor-Relator: Pablo Renteria. Presidente da sessão 
de julgamento: Leonardo P. Gomes Pereira. Data de Julgamento: 09.12.2015. Disponível

em: <http://www.cvm.gov.br/export/sites/cvm/sancionadores/sancionador/anex os/2015/20151209 PAS RJ20113823.pdf>.

Extrato da Sessão de Julgamento do Processo Administrativo Sancionador CVM n ${ }^{\circ}$ RJ2012/13047. Diretor-Relator: Roberto Tadeu Antunes Fernandes. Presidente da sessão de julgamento: Leonardo P. Gomes Pereira. Data de Julgamento: 04.11.2014. Disponível em: < $\underline{\text { http://www.cvm.gov.br/export/sites/cvm/sancionadores/sancionador/anex }}$ os/2014/20141104_PAS_RJ201213047.pdf>.

Extrato da Sessão de Julgamento do Processo Administrativo Sancionador CVM n RJ2012/7880. Diretor-Relator: Roberto Tadeu Antunes Fernandes. Presidente da sessão de julgamento: Leonardo P. Gomes Pereira. Data de Julgamento: 13.11.2013. Disponível em: <http://www.cvm.gov.br/export/sites/cvm/sancionadores/sancionador/anex os/2013/20131119_PAS_RJ20127880.pdf>.

Extrato da Sessão de Julgamento do Processo Administrativo Sancionador CVM n ${ }^{\circ}$ RJ2012/9808. Diretor-Relator: Roberto Tadeu Antunes Fernandes. Presidente da sessão de julgamento: Leonardo P. Gomes Pereira. Data de Julgamento: 18.12.2015. Disponível em: <http://www.cvm.gov.br/export/sites/cvm/sancionadores/sancionador/anex os/2015/20151218_PAS RJ20129808.pdf $>$.

Extrato da Sessão de Julgamento do Processo Administrativo Sancionador

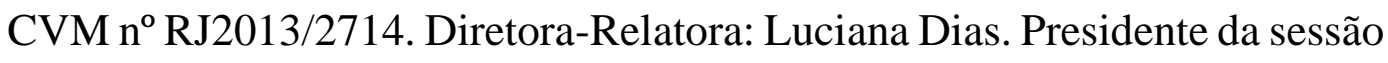
de julgamento: Leonardo P. Gomes Pereira. Data de Julgamento: 07.10.2014. Disponível em: < $\underline{\text { http://www.cvm.gov.br/export/sites/cvm/sancionadores/sancionador/anex }}$ os/2014/20141007 PAS RJ20132714.pdf>. 
Extrato da Sessão de Julgamento do Processo Administrativo Sancionador CVM nº RJ2013/1730. Diretora-Relatora: Luciana Dias. Declaração de Voto: Gustavo Tavares Borba Presidente da sessão de julgamento: Leonardo P. Gomes Pereira. Data de Julgamento: 18.08.2015. Disponível em: <http://www.cvm.gov.br/export/sites/cvm/sancionadores/sancionador/anex os/2002/20020417 PAS 1300.pdf>.

Extrato da Sessão de Julgamento do Processo Administrativo Sancionador CVM nº RJ2014/3225. Diretor-Relator: Roberto Tadeu Antunes Fernandes. Presidente da sessão de julgamento: Leonardo P. Gomes Pereira. Data de Julgamento: 13.09.2016. Disponível em: <http://www.cvm.gov.br/export/sites/cvm/sancionadores/sancionador/anex os/2016/20160913_PAS_RJ20143225.pdf>.

Extrato da Sessão de Julgamento do Processo Administrativo Sancionador CVM n ${ }^{\circ}$ TA-RJ2002/2405. Diretora-Relatora: Norma Jonssen Parente. Relator do Voto Vencedor: Luiz Antonio De Sampaio Campos. Presidente da sessão de julgamento: Wladimir Castelo Branco Castro. Data de Julgamento: 20.06.2006. Disponível em: <http://www.cvm.gov.br/export/sites/cvm/sancionadores/sancionador/anex os/2003/20031009_PAS_RJ20022405.pdf >.

Extrato da Sessão de Julgamento do Processo Administrativo Sancionador CVM nº SP2013/12. Diretora-Relatora: Luciana Dias. Presidente da sessão de julgamento: Leonardo P. Gomes Pereira. Data de Julgamento: 18.08.2015. Disponível em: < $\underline{\text { http://www.cvm.gov.br/export/sites/cvm/sancionadores/sancionador/anex }}$ os/2015/20150818_PAS_SP201312.pdf>.

Instituto Brasileiro de Relações com Investidores e Comissão de Valores Mobiliários. Relações com Investidores da Pequena Empresa ao Mercado de Capitais. em: 
<http://www.portaldoinvestidor.gov.br/portaldoinvestidor/export/sites/porta ldoinvestidor/publicacao/Livro/Livro-IBRI-CVM.pdf>.

INTERNATIONAL ORGANIZATION OF SECURITIES COMMISSIONS

- IOSCO. Insider Trading - How Jurisdictions Regulate It. Março de 2003. Disponível em: 〈www.iosco.org $>$.

MÜSSNICH, Francisco Antunes Maciel. O insider trading no direito brasileiro. São Paulo: Saraiva, 2017.

PARENTE, Norma Jonssen. Aspectos Jurídicos do "insider trading". Superintendência Jurídica, junho de 1978. Disponível em: <http://www.cvm.gov.br/export/sites/cvm/menu/acesso_informacao/seriesh istoricas/estudos/anexos/Aspectos-Juridicos-do-insider-trading-NJP.pdf > .

PARENTE, Norma Jonssen. Tratado de Direito Empresarial - Volume VI Mercado de Capitais. São Paulo, Editora Revistas dos Tribunais Ltda., 2016. Edição Thomson Reuters. Item 10.11 - Uso de informação privilegiada insider trading.

PROENÇA, José Marcelo Martins. Insider Trading - regime jurídico do uso de informações privilegiadas no mercado de capitais. São Paulo: Quartier Latin, 2005.

RANGEL, Paulo. Direito Processual Penal. 12 ${ }^{\mathrm{a}}$ edição. Rio de Janeiro: Editora Lumen Juris, 2007.

SIMONSEN, Mário Henrique. Exposição de Motivos do Senhor Ministro da Fazenda $\mathrm{n}^{\circ} 197$, o anexo projeto de lei que "dispõe sobre o mercado de valores mobiliários e cria a Comissão de Valores Mobiliários - CVM". Disponível em: <http://www.cvm.gov.br/export/sites/cvm/legislacao/leisdecretos/anexos/EM197-Lei6385.pdf>.

TRINDADE, Marcelo Fernandez. Vedações à Negociação de Valores Mobiliários por Norma Regulamentar: Interpretação e Legalidade. IN: VON 
ADAMEK, Marcelo Vieira. Temas de Direito Societário e Empresarial Contemporâneos. Malheiros Medidores, 2011. 